\author{
UNIVERSIDADE DE SÃO PAULO \\ ESCOLA DE ARTES, CIÊNCIAS E HUMANIDADES \\ PROGRAMA DE PÓS-GRADUAÇÃO EM ESTUDOS CULTURAIS
}

LUIS PEREIRA SILVA

“É o meu corpo que sustenta as minhas ideias": Corpo, comida e saúde na voz da militância gorda

São Paulo 


\title{
“É o meu corpo que sustenta as minhas ideias": Corpo, comida e saúde na voz da militância gorda
}

\author{
Versão corrigida
}

Dissertação apresentada à Escola de Artes, Ciências e Humanidades da Universidade de São Paulo para obtenção do título de Mestre em Filosofia pelo Programa de Pós-graduação em Estudos Culturais.

Versão corrigida contendo as alterações solicitadas pela comissão julgadora em 12 de agosto de 2019. A versão original encontra-se em acervo reservado na Biblioteca da EACH/USP e na Biblioteca Digital de Teses e Dissertações da USP (BDTD), de acordo com a Resolução CoPGr 6018, de 13 de outubro de 2011.

Área de Concentração:

Cultura e saúde

Orientador:

Prof. Dr. Régia Cristina Oliveira 
Autorizo a reprodução e divulgação total ou parcial deste trabalho, por qualquer meio convencional ou eletrônico, para fins de estudo e pesquisa, desde que citada a fonte.

Silva, Luis Pereira

"É o meu corpo que sustenta as minhas ideias": corpo, comida e saúde na voz da militância gorda / Luís Pereira Silva ; orientadora, Régia Cristina Oliveira. - 2019

$93 \mathrm{f}$.

Dissertação (Mestrado em Filosofia) - Programa de PósGraduação em Estudos Culturais, Escola de Artes, Ciências e Humanidades, Universidade de São Paulo, São Paulo.

Versão corrigida

1. Antropologia cultural e social - Brasil. 2. Corpo humano Aspectos sociais; Aspectos antropológicos. 3. Mulheres. 4. Obesidade - Aspectos sociais; Aspectos antropológicos. 5. Imagem corporal. 6. Militância. I. Oliveira, Régia Cristina, orient. II. Título

CDD 22.ed.- 306.0981 
Nome: SILVA, Luis Pereira

Título: "É o meu corpo que sustenta as minhas ideias": corpo, comida e saúde na voz da militância gorda.

Dissertação apresentada à Escola de Artes, Ciências e Humanidades da Universidade de São Paulo para obtenção do título de Mestre em Filosofia do Programa de Pós-Graduação em Estudos culturais.

Área de Concentração:

Cultura e saúde

Aprovado em: 12/08 /2019

\section{Banca Examinadora}

Prof. Dra. Idalice Ribeiro Silva Lima

Julgamento: Aprovado

Prof. Dra. Stella C. Schrijnemaekers

Julgamento: Aprovado

Prof. Dr. Edemilson A. de Campos

Julgamento: Aprovado
Instituição: UFTM

Assinatura:

Instituição: FESPSP

Assinatura:

Instituição: USP

Assinatura: 
À Maria Elena, minha mãe. A Valdélio, ao meu pai. À Denise, minha irmã. Aos meus irmãos Juquinha e Addae. 


\section{Agradecimentos}

Agradeço à CAPES pela bolsa concedida.

À Régia Oliveira, minha orientadora, pelo apoio na elaboração dessa dissertação, desde seu projeto até o texto final.

Às professoras Idalice Ribeiro e Stella C Schrijnemaekers pela grande colaboração na banca de qualificação.

Aos funcionários do Programa de Pós-Graduação em Estudos Culturais da EACH, pelo apoio nas diversas demandas durantes o período do mestrado.

Aos meus pais Valdélio e Maria Elena, meus irmãos Denise, Juquinha e Addae. O apoio e o carinho da minha família me dão condições de realizar essa pesquisa.

À Alana, minha companheira, pelas correções dos textos, pelo apoio irrestrito, por todo o carinho que me sustentou durante todo o processo.

À Livia, amiga querida, pelo apoio e por me ajudar nas correções.

Aos funcionários do Restaurante Central da USP, onde pude, durante quase 3 anos, me alimentar diariamente.

À assistência social da USP, na figura de Rosângela Dearo, por possibilitarem o acesso a moradia universitária

Aos funcionários da biblioteca da FEUSP, onde pude realizar parte significativa dessa dissertação.

À Fernanda, militante gorda que possibilitou o início desse estudo. 


\section{RESUMO}

SILVA, Luis Pereira. "É o meu corpo que sustenta as minhas ideias": Corpo, comida e saúde na voz da militância gorda. 2019. 93f. Dissertação (Mestrado em Filosofia) Escola de Artes, Ciências e Humanidades, Universidade de São Paulo, São Paulo, 2019. Versão corrigida.

A presente pesquisa investigou as os discursos sobre corpo, comida e saúde de mulheres que participam da chamada militância gorda. A referida militância é composta por pessoas autoafirmadas como gordas, que entendem que pessoas assim definidas sofrem uma forma de opressão social e com base nisso militam contra a estigmatização desses corpos e pelos direitos desses indivíduos em relação à sua autoafirmação. A pesquisa foi realizada com mulheres, da cidade de Salvador e de São Paulo, que declaravam fazer parte dessa militância. De caráter qualitativo, esse estudo se valeu da técnica de entrevistas semiestruturadas. Nas entrevistas as participantes dessa pesquisa foram instigadas a falar sobre a relação delas com a comida; o que pensavam sobre o discurso biomédico da obesidade; como se relacionavam com o próprio corpo. O pensamento biomédico, anatomofisiológico, considera a obesidade, antes de mais nada, uma anomalia. Portanto, intervenções de natureza tecnocientíficas são prescritas para esses corpos. Porém, apesar da biomedicina se ancorar em um discurso puramente biológico, há, inegavelmente, uma dimensão moral na busca da saúde. Nesse sentido, a obesidade, dentro do discurso biomédico, além de uma doença física, é também vista como uma doença moral. Buscou-se, portanto, investigar como os indivíduos dessa militância percebem-se a si mesmos e produzem sua relação com o próprio corpo e com sua alimentação, informados que também são por discursos biomédicos sobre o corpo gordo.

Palavras-chave: Gordofobia. Antropologia do corpo. Antropologia da saúde. Antropologia da alimentação. Obesidade. 


\begin{abstract}
SILVA, Luis Pereira. "It's my body that sustains my ideas": Body, food and health in fat activism's voice. 93p. Dissertation (Master of Philosophy) - School of Arts, Sciences and Humanities, University of São Paulo, São Paulo. 2019. Corrected version.

The present study explored discourses and the life experiences about body, food and health of women that are engaged with a social movement called fat activism. The referred activism is composed by individuals self-denominated as fat. The basis of this activism is the comprehension that fat people suffers from a kind of social oppression. The research was realized both in Salvador and São Paulo. Based on the qualitative methodology, this study used primarily the semi-structured interview technique. The participants were instigated to talk about their relationship with food; what they think about the biomedical views on obesity; the relationship with their own bodies. The biomedical institution sees obesity as disease. Therefore, technoscientific interventions are prescribed to those bodies. However, despite selling itself as "neutral" science, without any bias, there is a moral dimension on biomedicine practice. Therefore, this research inquired the participants to speak about those issues in their perspective.
\end{abstract}

Keywords: Fatphobia. Body anthropology. Health anthropology. Food anthropology. Obesity. 


\section{SUMÁRIO}

1 INTRODUÇÃO

$1.1 \quad$ Objetivos

\section{Capítulo I - METODOLOGIA E TÉCNICA DE PEQUISA}

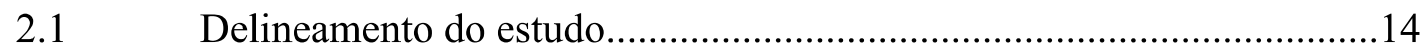

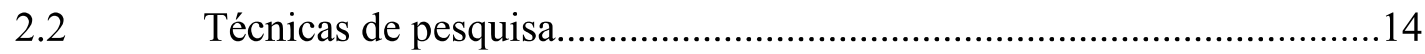

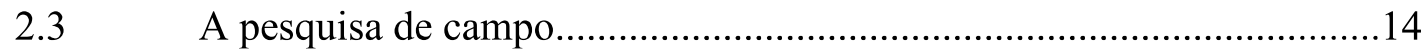

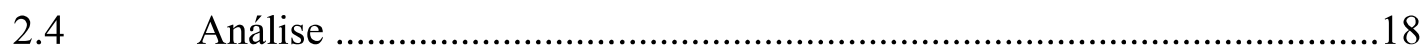

3 Capítulo II - CORPO E MILITÂNCIA

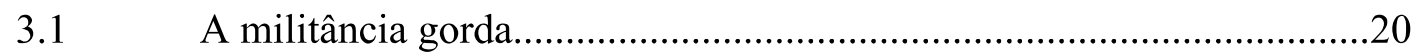

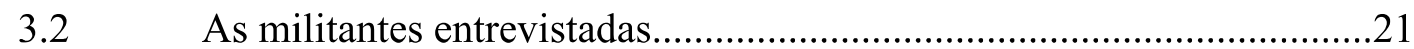

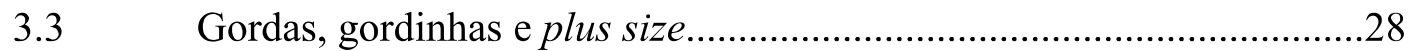

4 Capítulo III - CORPO E SAÚDE

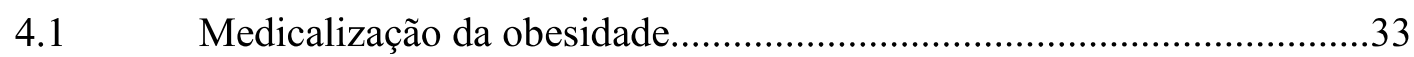

4.2 Violência institucional e estigma da obesidade....................................42

5 Capítulo IV - CORPO E COMIDA

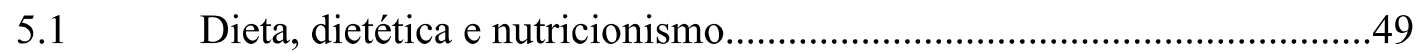

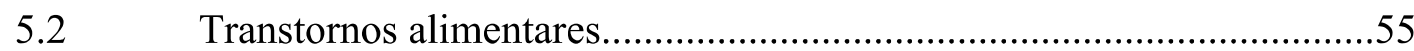

6 A MILITÂNCIA ENQUANTO HORIZONTE DE

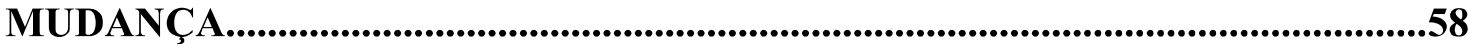

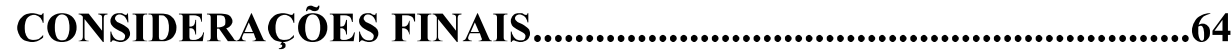

REFERÊNCIAS....................................................................................66

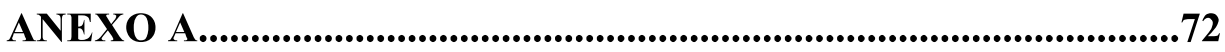

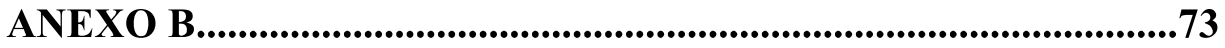




\section{INTRODUÇÃO}

As inquietações acerca do meu objeto de pesquisa surgiram durante meu processo de formação como profissional de cozinha. O diálogo com a nutrição é uma constante na vida de profissionais de cozinha, seja no contato direto com nutricionistas de escolas de formação ou de restaurantes, seja pelo discurso veiculado por televisão, jornais, revistas etc. Era comum a intervenção de nutricionistas na cozinha do restaurante-escola onde me formei, sempre no sentido de tornar as comidas "mais leves", "mais saudáveis" e "mais seguras", em oposição aos alimentos ditos "pesados", "ruins" ou "sujos". Era comum também que o discurso da nutrição fosse reverberado pelos cozinheiros e cozinheiras. Substituições, subtrações e incorporações em receitas da culinária local eram comuns: por exemplo, trocar o azeite de dendê por extrato de tomate, "refogar" na água em vez de refogar na manteiga, não usar mocotó na feijoada, arroz integral em vez de arroz branco, exclusão da farinha de mandioca etc. Nesse contexto, eu ia percebendo que muitos pratos e ingredientes da culinária local iam perdendo espaço, não só nos locais de formação de cozinheiros, mas também nas práticas dos restaurantes populares, para preparações que eram consideradas saudáveis. Essas inquietações me levaram a escrever um projeto de pesquisa no qual buscava discutir as apropriações e ressignificações do discurso biomédico / nutricionista sobre a alimentação por camadas populares da sociedade.

Em um outro momento, ao cursar a disciplina "Sociologia do Corpo, da Saúde e da Doença”, da professora e minha atual orientadora Régia Oliveira, entrei em contato com discussões relacionadas ao corpo nas sociedades contemporâneas. Nela, que teve como suporte teórico autores como Le Breton, Laplantine e Herzlich, foram discutidos os sentidos e os usos do corpo numa sociedade onde a biomedicina, com seus saberes e práticas, tem status hegemônico. Que noção de corpo tem a biomedicina? Como ela pensa a saúde e a doença? Como os indivíduos apreendem e reelaboram esse saber? Ao longo da disciplina fui percebendo a proximidade e os cruzamentos que existiam entre a questão do corpo e da alimentação, como a busca do ideal de magreza, a "desintoxicação" do corpo etc. Ao mesmo tempo, vivências pessoais, enquanto alguém que passou a maior parte da vida fora do peso "normal", também foram emergindo nesse processo, como a pressão da família e médicos para emagrecer e os conselhos sobre alimentação saudável.

Porém, no primeiro projeto de pesquisa que elaborei para a seleção do meu atual programa, não inclui as discussões sobre corpo. Após ser aprovado na seleção, comecei 
a reelaborar o projeto no sentido de incorporar as questões ligadas ao corpo. Nesse processo, entrei em contato, através de redes sociais, com a chamada militância gorda ou antigordofobia. Trata-se de um movimento social, composto majoritariamente por mulheres, que luta contra a estigmatização dos corpos gordos. Essa militância se expressa através do tensionamento com o saber biomédico sobre o corpo gordo; contra a perpetuação do ideal magro de beleza pelos diversos suportes midiáticos, como cinema, televisão, revistas; pelo acesso a tratamentos de saúde; pelo acesso a roupas adequadas, entre outros fatores.

O pensamento biomédico, anatomofisiológico, considera a obesidade, antes de mais nada, uma anomalia (Poulain, 2011). Portanto, intervenções de natureza tecnocientíficas são prescritas para esses corpos. Porém, apesar da biomedicina se ancorar em um discurso puramente biológico, há, inegavelmente, uma dimensão moral na busca da saúde (Russo; Souza e Pitanguy, 2006). Nesse sentido, a obesidade, dentro do discurso biomédico, além de uma doença física, é também vista como uma doença moral (Poulain, 2011). Expressões como "epidemia de obesidade" ou "guerra à obesidade" são bastante comuns no âmbito da saúde. Em resposta a isso, o emagrecimento através da mudança de práticas alimentares é uma das principais estratégias biomédicas de combate à obesidade. (Poulain, 2013).

Essa visão, junto com as práticas, saberes e intervenções sobre o corpo, tem status hegemônico na sociedade (McCollum et al, 2015: 8). Porém, essa hegemonia opera em constante conflito com outras visões de mundo. A militância gorda (ou militância antigordofobia) atua enquanto movimento de resistência à visão estritamente biomédica sobre o corpo gordo. Uma resistência que se mostra complexa: dialoga, rejeita, e concorda com a lógica biomédica. E que quer também produzir novas formas de vida. Trabalho com a hipótese de que a militância antigordofobia é expressão de uma crise da instituição médica centrada no modelo anatomofísiológico, que não dá conta, nessa chave de compreensão puramente biológica do corpo, de responder a novas demandas do corpo que busca não se assujeitar a uma definição preconcebida de normalidade e patologia.

Tendo como ponto de partida os temas - muitas vezes indissociáveis - corpo, saúde e comida, e, reconhecendo a importância que estes ocupam na vida das pessoas gordas, realizei oito entrevistas, na cidade de Salvador (BA) e na cidade de São Paulo (SP), com mulheres autorreferidas como militantes. Busco nessa pesquisa evidenciar narrativas que, 
atravessadas pela luta em comum desse grupo, pudessem mostrar novos saberes e práticas que tensionam com a visão hegemônica sobre o corpo gordo.

No primeiro capítulo, discuto as estratégias metodológicas empregadas nesta pesquisa. Inicialmente apresento o delineamento do estudo. Em seguida, faço uma discuto as técnicas de pesquisa utilizadas. Depois, faço uma descrição do trabalho de campo, fazendo uma apresentação inicial das entrevistadas nesta pesquisa. Finalmente, apresento a forma de análise do material produzido no campo.

No segundo capítulo, abordo a questão da militância gorda em si. Primeiro, faço uma breve introdução a história dessa militância no mundo. Em seguida, faço uma apresentação mais aprofundada das militantes entrevistadas e da relação das mesmas com a militância gorda. No final do capítulo, discuto os conceitos de gorda, gordinha e plus size, a partir da fala das entrevistadas.

No terceiro capítulo, abordo as relações entre corpo gordo e saúde. No primeiro item será descrito o processo de medicalização da obesidade, evidenciando como a gordura corporal foi, através da história, se tornando jurisdição da biomedicina. Em seguida, discuto as controvérsias no campo da biomedicina em relação ao status que a obesidade carrega hoje e, a partir disso, analiso como as entrevistadas pensam o conceito de obesidade; do corpo gordo enquanto corpo doente. No item seguinte discuto a relação entre o estigma do corpo gordo e violência institucional. Abordo discuto o conceito de estigma em Goffman e questões relativas à percepção do corpo gordo durante a história. No item final, abordo a noção de cuidado com a saúde entre as entrevistadas.

No quarto capítulo, trato da relação entre corpo gordo e comida. Inicialmente, discuto as percepções sociais da alimentação da pessoa gorda, analisando como essas percepções foram se transformando ao longo da história. Em seguida, abordamos a questão da dieta na vida das pessoas gordas. Discuto a prática da dieta atualmente e durante a história, tendo em perspectiva a experiência das entrevistadas quanto a essa questão. E, finalmente, no último tem, analiso o papel que a militância exerceu na vida das entrevistadas.

\subsection{Objetivos}

Objetivou-se nesta pesquisa investigar a relação entre corpo, comida e discurso científico para os indivíduos da chamada militância antigordofobia, buscando-se 
apreender como elas se percebem na relação com seu próprio corpo e com a alimentação e de que maneira se contrapõem ao discurso biomédico sobre obesidade.

Objetivos específicos:

- Investigar as pautas dessa militância

- Investigar o discurso biomédico sobre obesidade

- Colocar em evidência a percepção de pessoas ditas gordas sobre seus corpo, alimentação e biomedicina 


\section{Capítulo I - METODOLOGIA E TÉCNICA DE PESQUISA}

\subsection{Delineamento do estudo}

Tendo em vista a natureza interpretativa desta investigação, foi utilizada a abordagem qualitativa. Segundo Minayo (2014), o método qualitativo "se aplica ao estudo da história, das relações, das representações, das crenças, das percepções e das opiniões, produtos das interpretações que os humanos fazem a respeito de como vivem (...)". Ainda segundo a autora, esse método permite "desvelar processos sociais ainda pouco conhecidos dos referentes a grupos particulares". Entende-se que essa abordagem é ideal para a presente pesquisa, pois a investigação por ela proposta gira em torno das representações, significados e valores dos indivíduos / grupo pesquisado.

\subsection{Técnicas de pesquisa}

Esta pesquisa contou com a participação de 6 mulheres, 4 de Salvador, BA; 3 de São Paulo, SP. O único critério para inclusão era autodeclarar-se como militante da causa gorda / antigordofobia. A pesquisa teve início com uma única informante (em Salvador) que, após contato inicial, me apresentou outras militantes da mesma causa. O mesmo se deu em São Paulo, onde uma informante inicial apresentou outras militantes. A técnica de-pesquisa utilizada para a localização das informantes foi a do snowballing (Krippendorff (2004). Nessa técnica, um informante vai indicando outro ou outros possíveis novos informantes para participarem da pesquisa. Esse novo informante também indica outra pessoa, a partir da solicitação do pesquisador e assim por diante, até que se chegue à saturação dos dados. Outra importante técnica utilizada foi a entrevista semi-estruturada. Esta técnica "combina perguntas fechadas e abertas, em que o entrevistado tem a possibilidade de discorrer sobre o tema em questão sem se prender à indagação formulada" (Minayo, 2010, p. 261). Tendo em vista as questões propostas por esta investigação, optou-se, portanto, por essa técnica de entrevista.

\subsection{A pesquisa de Campo}

Durante o primeiro semestre do mestrado, contatei através da rede social Facebook, grupos e pessoas que escreviam sobre a questão da gordofobia. Tive retorno de apenas um grupo, que tinha integrantes na cidade do Rio de Janeiro e na cidade de São Paulo. Porém, após uma conversa inicial onde expliquei a pesquisa e perguntei sobre a 
possibilidade de realizar entrevistas, não obtive retorno. Inicialmente não tinha a intenção de fazer a pesquisa junto a um grupo específico, mas com diversas pessoas que se autodeclarassem como militantes da questão da gordofobia. No mês de junho viajei para Salvador, minha cidade natal, onde, numa conversa com um amigo, consegui o contato de Simone ${ }^{1}$, pessoa que faz parte de um grupo chamado "Movimento Gordo na Bahia", que milita na questão das pessoas gordas. Nesse contato foi discutido a disponibilidade do grupo para pesquisa e foi realizada uma conversa informal em que apresentei o que pretendia pesquisar. Junto a esse grupo foram realizadas quatro entrevistas. Não havia, $a$ priori, um número estabelecido de entrevistas, a método utilizado era o da saturação ou “exaustação de dados”. Dessa forma, voltando à São Paulo, busquei outras pessoas militantes a fim de entrevistar. Mais uma vez, através de uma amiga, consegui o contato de uma militante.

As entrevistas foram realizadas em diversos locais, como a casa das entrevistadas, cafés, bibliotecas públicas, etc. Para tal, foram utilizados um aplicativo de gravação de som de um smartphone. Nas entrevistas foram abordadas a história de vida alimentar ${ }^{2}$ dos sujeitos, a relação com o próprio corpo durante a vida, a relação das entrevistadas com profissionais de saúde e o saber médico-científico e a história das entrevistadas com a militância em particular. Para cada uma dessas questões, foi pedido para que as entrevistadas comentassem tanto sobre experiências mais antigas (infância e adolescência), quanto na idade adulta, em especial a partir da entrada na militância referida. Questionamentos surgidos durante a entrevista também foram feitos. As entrevistas não tinham uma duração pré-estabelecidas, mas duraram, e média, 1h:20m. Após cada entrevista, foi feito um diário de campo a fim de anotar as impressões imediatas que surgiram. Posteriormente, as entrevistas foram transcritas para texto.

A conversa foi bastante produtiva, durando cerca de uma hora e meia. Descobri nessa conversa que o grupo citado é bastante consolidado: organiza encontros entre pessoas gordas, faz ações junto à população e dialoga com o poder público, através de reuniões com as Secretarias de Saúde do estado e município e com deputados e vereadores.

Em dezembro, de volta à Salvador, comecei a escrever o roteiro de entrevista. Revi a bibliografia da disciplina "Introdução à Pesquisa em Alimentação", em especial os textos

\footnotetext{
${ }^{1}$ Os nomes das entrevistadas são fictícios, a fim de preservar a identidade das mesmas.

${ }^{2}$ Esse conceito trazido por Poulain e Proença (2003), busca "fazer emergir, dentre outras, as grandes transformações de práticas, de gostos, de estatuto ponderal, nos contextos biográficos dos entrevistados".
} 
relacionados à pesquisa em profundidade, reli o projeto de pesquisa e comecei a elaborar as perguntas. O roteiro foi elaborado com a intenção de ter perguntas "gatilhos", onde as entrevistadas pudessem falar com alguma liberdade sobre os temas por mim propostos. Na segunda semana de dezembro, contatei Simone novamente e assim consegui agendar uma entrevista. A entrevista foi realizada, por escolha dela, na sua casa. Simone, que já tinha se mostrado solicita desde o primeiro contato, continuou a mostrar e interesse e vontade de contribuir com a pesquisa em questão. A entrevista fluiu bastante, durando cerca de uma hora. O roteiro de entrevista foi pouco utilizado durante a entrevista, já que Simone, na sua fala, acabou por encadear os temas que o roteiro abordava.

Descobri que o grupo o qual Simone faz parte conta com cinco coordenadoras. Finalizada a entrevista, pedi que Simone entrasse em contato as demais integrantes avisando que eu iria entrar em contato com elas. Não tinha um número fechado de entrevistas a realizar - seguiria o critério da "exaustão de dados", entrevistando pessoas que frequentassem as ações propostas pelo grupo. Porém, conhecendo melhor a composição do grupo, quem organizava as ações, quem se envolvia mais com a militância, resolvi focar a investigação nesses sujeitos e em seus discursos, tendo em vista o engajamento das mesmas com a militância.

Nas semanas seguintes entrevistei Lígia e Carla. Essas duas entrevistas, também a pedido das entrevistadas, foram realizadas numa biblioteca pública de Salvador. Com Carla a entrevista, que durou cerca de quarenta minutos, foi um pouco mais travada. Senti um pouco de dificuldade de aprofundar certas questões. Além do fato dela ser mais sucinta em suas respostas, percebi ali que havia divergências dentro do próprio grupo. Enquanto havia uma forte oposição ao discurso hegemônico sobre saúde e, especificamente, sobre a saúde das pessoas gordas em Simone, com Carla percebi uma ambiguidade maior, com momentos de concordância e de oposição. Nesse sentido, acredito ter existido um "boicote" inconsciente da minha parte à entrevista, já que, pessoalmente, me coloco "ao lado" dos que se opõem ao discurso hegemônico. Com Lígia, que também diz divergir de certas posturas de oposição ao discurso biomédico sobre a obesidade, a entrevista conseguiu se desenvolver mais. Como destaca Da Matta (1978), é preciso realizar no trabalho de campo um duplo ofício: transformar o exótico em familiar e o familiar em exótico. Dessa forma, foi necessário transpor convicções pessoais em relação ao discurso das entrevistadas e me abrir ao que a pesquisa estava desvelando nas interações pesquisador - pesquisado. Um movimento que não foi fácil. 
Um outro importante fato referiu-se à atenção às questões propostas no roteiro. A entrevista com Carla fez com que fossem acrescentadas algumas questões ao roteiro, sobretudo sobre a relação das entrevistadas com profissionais de saúde.

Com essa entrevistada, a entrevista durou cerca de uma hora e meia. Foi feito um contato inicial com as duas integrantes restantes do grupo. porém, após tentar combinar um dia para a entrevista, as duas pararam de se comunicar comigo sem nenhuma explicação aparente. Todavia, essas recusas de participação, embora o aceite inicial do/a participante da pesquisa, não é algo incomum no trabalho de campo, devendo haver bastante atenção do pesquisador para também respeitar essas desistências. O trabalho de campo, segundo Da Matta (1978: 3), deve ser realizado de maneira artesanal e paciente, pois depende "de humores, temperamentos, fobias e todos os outros ingredientes das pessoas e do contato humano".

Dificuldades como esta da desistência de participação eram, de certa forma, previstas por mim. Antes de iniciar o campo, me perguntava se seria visto pelas entrevistadas como estranho (pesquisador na USP, classe média) ou como familiar (negro, baiano). Como destaca Sarti (2003), o confronto entre pesquisador e pesquisado pode resultar numa atitude defensiva por parte do pesquisado, como parece ter acontecido com as duas integrantes do grupo.

Voltando a Salvador, no mês de junho, voltei a entrar em contato com Cecília, fundadora do grupo e que não havia consigo entrevistar. Cecília prontamente aceitou uma nova tentativa de encontro que, dessa vez, foi bem sucedida. A entrevista transcorreu bem e nela pude ter insights maiores sobre a formação do grupo e, também, sobre a intersecção entre a questão da gordofobia e classe social.

Voltando a São Paulo e, sentindo que os temas ainda não haviam se esgotado, procurei por novas militantes para entrevistar. Entrei em contato com algumas pessoas proeminentes na militância das redes sociais, incluindo homens. Porém, após tentar contato através de diversas redes sociais, não obtive resposta. Mais uma vez, então, consegui através de uma amiga o contato de alguém engajado na militância gorda: Lúcia. Encontrei Lúcia incialmente para um almoço informal, onde expliquei a minha pesquisa e comentei um pouco sobre as pessoas que já havia entrevistado. Lúcia se mostrou interessada e solicita e, algumas semanas depois, marcamos uma entrevista. A entrevista ocorreu na sua casa / estúdio de Yoga. Nela foi possível compreender mais sobre o contexto paulistano da militância, e a importância do discurso cultural que ela tem. A partir de Lúcia, consegui os contatos de Tereza, que entrevistei algumas semanas depois. 
2.3.1 Tabela com informação das entrevistadas

\begin{tabular}{|l|l|l|l|l|l|l|}
\hline Nome & Idade & Escolaridade & $\begin{array}{l}\text { Local de } \\
\text { Moradia }\end{array}$ & Cor/Etnia & $\begin{array}{l}\text { Estado } \\
\text { Civil }\end{array}$ & $\begin{array}{l}\text { Tempo de } \\
\text { militância }\end{array}$ \\
\hline Simone & 30 anos & $\begin{array}{l}\text { Ensino } \\
\text { superior }\end{array}$ & $\begin{array}{l}\text { Salvador, } \\
\text { Bahia. }\end{array}$ & Preta & Solteira & 4 anos \\
\hline Carla & 29 anos & $\begin{array}{l}\text { Ensino } \\
\text { superior }\end{array}$ & $\begin{array}{l}\text { Salvador, } \\
\text { Bahia. }\end{array}$ & Preta & Solteira & 4 anos \\
\hline Cecília & 32 anos & $\begin{array}{l}\text { Ensino médio } \\
\text { Lígia }\end{array}$ & $\begin{array}{l}\text { Salvador, } \\
\text { Bahia. }\end{array}$ & Preta & Solteira & 6 anos \\
\hline Lúcia & 38 anos & $\begin{array}{l}\text { Ensino } \\
\text { superior } \\
\text { incompleto }\end{array}$ & $\begin{array}{l}\text { Salvador, } \\
\text { Bahia. }\end{array}$ & Preta & Solteira & 4 anos \\
\hline superior & $\begin{array}{l}\text { São } \\
\text { Paulo, } \\
\text { São } \\
\text { Paulo. }\end{array}$ & $\begin{array}{l}\text { São } \\
\text { Paulo, } \\
\text { São } \\
\text { Paulo. }\end{array}$ & Branca & Casada & Solteira & 2 anos \\
\hline superior & 31 anos & Ensino & anos & & \\
\hline
\end{tabular}

\subsection{Análise}

O método utilizado para analisar os resultados foi o da análise de conteúdo. Análise de conteúdo é um método para análise de dados subjetivos através do processo de codificação e de identificação de temas (Hsieh, 2005). A análise de conteúdo tem quatro etapas principais: pré-análise, codificação, categorização e análise. Durante a préanálise foi realizada a chamada "leitura flutuante" dos textos, onde foram selecionados os textos (entrevistas) a serem analisados. Nesse momento, tendo como ponto de partida os objetivos da pesquisa, os possíveis temas começaram a ser identificados. Inicialmente, foram identificados 9 temas. Posteriormente, estes foram reduzidos à 6. Com as 
entrevistas impressas, os parágrafos que diziam respeito aos temas escolhidos foram sendo destacados com marcadores de texto de cores diversas e, posteriormente, recortados e colocados em um quadro de cortiça. Nesse momento, algumas notas (insights) foram sendo feitas sobre os parágrafos recortados, assim como a associação dos mesmos à referência bibliográfica previamente pesquisada. Em seguida, com cada tema identificado, foi montado um codebook no Word, que constava do título do tema, uma descrição curta e outra detalhada do mesmo e de um exemplo de um parágrafo pertinente ao tema. Todas os parágrafos a serem utilizados foram agregados no mesmo arquivo. 


\section{Capítulo II - CORPO E MILITÂNCIA}

\subsection{A militância gorda}

A militância gorda é parte de um movimento social, composto predominantemente por mulheres, que luta contra a estigmatização dos corpos gordos. Essa militância se expressa através da problematização e do tensionamento com os saberes biomédicos sobre o corpo gordo; contra a perpetuação do ideal magro de beleza veiculados pelos suportes midiáticos, como cinema, televisão, revistas; pelo acesso a tratamentos de saúde; pelo acesso no mercado às roupas adequadas, entre outros fatores. Segundo Cooper (2008) essa militância surge no final da década de 60 nos Estados Unidos, mesma época da luta pelos direitos civis. Cooper divide a história desse ativismo, a exemplo do feminismo, em três ondas.

A primeira, entre os anos de 1967 e 1989, foi marcada pelo surgimento de grupos como The Fat Undergroud e The London Fat Women's Group, que eram compostos quase que exclusivamente por mulheres lésbicas que militavam em grupos feministas. Através de protestos públicos e publicações locais, as ações desses grupos eram direcionadas principalmente à questão da estigmatização ${ }^{3}$ das pessoas gordas.

A segunda onda, que começa por volta da década de 90 , é marcada pela entrada dessa militância no mainstream. Em vez de pequenos grupos isolados, a questão da estigmatização do corpo gordo começa a se tornar uma pauta coletiva, com o surgimento de eventos, debates públicos, grupos e diferentes abordagens. Outras questões passaram a ser discutidas, como as controvérsias científicas sobre os males da obesidade e a demanda por representatividade no mundo da moda. Segundo Cooper (2008), as ideias do ativismo gordo na indústria da moda foi o grande fator para que essas ideias alcançassem o mainstrem. Esse período também é marcado pelo surgimento de pesquisas científicas que questionavam a percepção hegemônica biomédica sobre a obesidade.

A terceira onda, dos anos 2000 até agora, é marcada pelo crescimento exponencial dos grupos envolvidos com esse ativismo, com isso, as discussões alcançam um status mais elevado nas discussões dentro da academia e, ao mesmo tempo, se volta contra a fixação do status de epidemia da obesidade.

No momento atual, onde há uma considerável diversidade de grupos e indivíduos que atuam nessa militância, é um desafio inalcançável ter uma definição única do que é a

\footnotetext{
${ }^{3}$ Segundo Goffman (1988), o estigma é um atributo depreciativo, que não é em sim mesmo ruim, mas que diferencia o indivíduo estigmatizado perante o outro, o normal.
} 
militância gorda. Segundo Cooper, o chamado fat activism é composto de múltiplas práticas que se entendem como ativismo. $\mathrm{Na}$ busca de uma síntese para ordenar as diferentes práticas de militância, Cooper identifica cinco formas de ativismo: Ativismo político; comunidades ativistas, ativismo gordo enquanto ação cultural; micro ativismo gordo e ativismo gordo ambíguo ${ }^{4}$ é a forma de ativismo que busca se engajar junto ao poder público afim de reivindicar direitos para a sua causa. Esse engajamento pode ser a proposição de leis específicas para uma determinada população, criação de políticas públicas. Comunidades ativistas se refere ao ativismo baseado na formação de redes. Essas redes seriam compostas por indivíduos que se identificam como gordos ou que pela temática se interessam. A centralidade desse ativismo está na troca de experiências e saberes, não necessariamente se engajando em outras ações. ativismo gordo enquanto ação cultural é forma de militância onde a produção criativa é objeto central, podendo se manifestar coletivamente ou de maneira individual. Música, artes visuais, música, eventos, festas podem ser formas de expressão dessa militância. Micro ativismo gordo, segundo a autora, seria uma forma de militância individual, onde não há um engajamento coletivo. Esse tipo de militância se expressa, sobretudo, nas relações interpessoais, em momentos da vida cotidiana. E, finalmente, ativismo gordo ambíguo seria a militância que não se encaixa em nenhuma das categorias descritas acima.

\subsection{As militantes entrevistadas}

As entrevistadas Lígia, Simone, Carla e Cecília fazem parte de um mesmo grupo, o Movimento Gordo da Bahia, que pode ser considerado, segundo a classificação de Cooper, como ativismo político. Segundo Lígia, a sua organização

(...) pauta as questões da população gorda, sobretudo das mulheres gordas negras, nos diversos âmbitos, desde a acessibilidade nos âmbitos urbanos, tanto privados como públicos, no âmbito da empregabilidade, a saúde, o acesso ao tratamento de saúde, as lutas diversas contra a falta de humanização no tratar da nossa saúde.

O grupo começou a se articular através de redes sociais, em especial Orkut e Facebook. As atuais componentes do grupo se conheceram através de um grupo do Facebook chamado "Gordinhas Lindas da Bahia - Oficial”, um grupo de paquera utilizado por mulheres gordas e pessoas, principalmente homens, que se interessam por esse perfil

\footnotetext{
${ }^{4}$ Orginal: political process activism, activist communities, fat activism as cultural work, micro fat activism and ambiguous fat activism. Political process activism
} 
de mulheres. A partir das discussões engendradas no citado grupo, foi criado um outro grupo, chamado de "Debates sobre Gordofobia". A partir da criação desse último, que tem um nome revelador de um estágio do movimento mais preocupado em participar da discussão sobre o tema de uma maneira mais qualificada, os contatos entre as participantes se estreita e, posteriormente, as integrantes transformam a organização virtual no atual grupo presencial. Essa militância, além das discussões promovidas através das redes sociais, organiza também "rodas de conversa", encontros com vereadores, deputados, representantes do Governo do Estado da Bahia e Prefeitura Municipal de Salvador. Promovem também eventos públicos onde buscam dar visibilidade à causa em questão.

Apesar de defender os direitos da população gorda em geral, o grupo, segundo defende sua coordenação, por uma opção política e de gênero ${ }^{6}$, é composta apenas por mulheres. Sobre esse posicionamento, Lígia afirma:

É um movimento que trabalha com pessoas gordas, tanto homens quanto mulheres, porém, o enfoque da mulher, que é quem sofre mais com a gordofobia, por até opressões estéticas, sociais, sociocultural (...)

Das cinco integrantes da coordenação do grupo, quatro são negras. A questão étnico-racial aparece enfaticamente na fala de todas as entrevistadas. Segundo Carneiro (1995: 545), “as mulheres negras são socialmente desvalorizadas em todos os níveis Inclusive esteticamente (...)". Apesar de a questão racial não ser cerne da militância em questão, ela foi destacada diversas vezes pelas entrevistadas. Como destaca Carneiro (2003), as mulheres negras sofrem uma "dupla subvalorização", por sofrer a questões relativas ao racismo e ao sexismo. Ainda segundo os relatos, todas as participantes são oriundas de famílias de baixa renda. Possivelmente estimuladas pela expansão vertiginosa do ensino público universitário nos últimos anos na Bahia e também pela adoção das políticas de ações afirmativas ${ }^{7}$, três integrantes da coordenação do grupo possuem nível

\footnotetext{
${ }^{5}$ Forma de encontro onde um determinado grupo de pessoas se reúnem para debater determinados assuntos de seus interesses. O termo é usado, principalmente, por movimentos sociais, como o feminista, LGBT, antirrascista, etc (Sampaio et al, 2014).

${ }^{6}$ Segundo Guedes (1995), definir gênero é uma tarefa complicada, dada a multiplicidade de significações conferidas a esse conceito. Gênero é entendido aqui, como em Scott (1995) que afirma que gênero é o gênero é "um elemento constitutivo de relações sociais baseadas nas diferenças percebidas entre os sexos e (...) o gênero é uma forma primária de dar significado às relações de poder.".

${ }^{7}$ Segundo Gomes (2001), as ações afirmativas "consistem em políticas públicas (e também privadas) voltadas à concretização do princípio constitucional da igualdade material e à neutralização dos efeitos da discriminação racial, de gênero, de idade, de origem nacional, de compleição física e situação socioeconômica ( adição nossa). Impostas ou sugeridas pelo Estado, por seus entes vinculados e até mesmo por entidades puramente privadas, elas visam a combater não somente as manifestações flagrantes de discriminação, mas também a discriminação de fundo cultural, estrutural, enraizada na sociedade."
} 
superior. Das quatro entrevistadas, todas afirmaram estar na chamada "faixa de obesidade", que é quando o IMC de uma pessoa está acima de 30. Todas essas características são fundamentais para se entender as pautas dessas mulheres.

Cada uma delas tem uma história sobre como começou a fazer parte da militância: Mais ou menos essa época que começou minha relação com a militância. Eu peguei amizade com uma menina, que, por acaso, estava em um grupo chamado "Gordinhas lindas da Bahia". Eu achava muito estranho. Me perguntava: "o que que essa menina quer? Ela tá maluca? Grupo de meninas gordas?!’. Aí eu fui olhar. Tinha um monte de postagem de incentivo e muita discussão. Aí eu comecei a entrar nesse mundo. No mundo gordo. Do que era real, do que era mentira, do que era ser gordo (Simone)

E a gente se conheceu através dos grupos do Facebook, de um dos grupos de entretenimento que o movimento administra, que é o Gordinhas Lindas da Bahia-Oficial e tem também o Gordinhas de Elite - Oficial, que são grupos pra entreter, tem dinâmicas, de saúde à sexualidade da mulher gorda, tem protesto contra o machismo, tem ações, encontros, pra trocar experiências, dar risadas, rodas de conversa com teor do nosso bem viver, como teor da questão do racismo, do machismo, quanto isso não influência a nossa vida e a gente se conheceu tem cinco anos mais ou menos. (Lígia)

Assim, foi uma coisa bem inusitada, tava no hospital de acompanhante com minha avó, e aí tinha uma acompanhante do meu lado e ela falou "eu vou lhe colocar num grupo pra você passar o tempo enquanto você tá aqui no hospital", ela me colocou no grupo. Então era só um grupo de amizade, aí conversando com as meninas do grupo, que foi Cecília, Simone, ai falaram "não, a gente faz esse trabalho de militância, de levantar a estima da mulher gorda, delas tá saindo mais, tá aparecendo nos locais”, e aí me chamou e comecei a participar com as meninas, com Simone, com Cecília, Viviane. E logo depois entrou a outra que foi Lígia. Ai a gente começou esse trabalho de roda de conversa. (Carla)

O depoimento de Cecília, fundadora do Movimento Gordo da Bahia, detalha a história desse grupo, suas motivações iniciais, as variações discursivas e as mudanças organizacionais ao longo dos últimos sete anos, além de oferecer uma visão mais ampla do surgimento do grupo em questão:

O grupo... o grupo no facebook, né, nós criamos há seis anos, seis, sete anos... quando o facebook começou, no caso, a ganhar espaço aqui no Brasil, o Orkut não tinha a mesma 
serventia, o grupo resistia no Orkut, as Gordinhas Lindas da Bahia, existia uma comunidade no Orkut. Nós tivemos necessidade de passar pro facebook porque não encontrava... eu fui fazer uma pesquisa, primeira vez que fui acessar ofacebook fui fazer uma pesquisa procurando, pra procurar aquelas pessoas que eu me relacionava no Orkut e eu não encontrei, encontrava muita coisa de mulheres gordas, mais pelo lado do Sul. E aí eu fui no Orkut, pedi autorização à antiga coordenadora do grupo na fase do Orkut e ela permitiu que ela criasse o grupo no facebook, nós criamos o grupo no facebook e pra resgatar essas pessoas do Orkut. Pra voltar à reunir essas pessoas, eu não tinha nenhuma intenção de... que fosse o que é hoje, no caso, de ter a parte coletiva, não pensava nisso. Era realmente naquele momento, era realmente uma coisa de diversão mesmo, uma coisa estética, algo pra namoro mesmo, antigamente existia, baseado nessas coisas. Mas aí sentamos pra falar sobre fazer lago pra que essas mulheres, é... se exercitassem, no caso nós sentamos, nós, administradores, sentaram pra conversar sobre o que a gente poder fazer pra melhorar a vida da população gorda de Salvador. Aí resolvemos fazer uma caminhada como um ato de... um primeiro ato relacionado, aí nós fizemos uma caminhada no dique que foi, que a gente colocou o nome "Gordinhas em movimento". E ai partir daí a gente começou a gente a entender e conhecer outras pessoas de militância, de outras militâncias e elas passaram a me orientar e a me instruir como as coisas poderiam ser e ai que é isso, essa vontade de fazer com que a gente pudesse ter políticas públicas destinadas à população gorda. Com relação aos ônibus que nós tínhamos dificuldades, à relação de saúde, relação até mesmo de termos, de, somos muitos cobrados com relação à perder peso, a manter a saúde e as pessoas acham que manter a saúde é só o emagrecimento e nós estávamos bem com os nossos corpos. Porém eu tenho consciência que nós éramos sedentárias e esse era, naquele momento, o principal, que a gente saísse do sedentarismo. E por isso nós criamos essa primeira caminhada e que, no caso, foi o primeiro ato e que depois viria acontecer aulas semanais no Dique . $^{8}$ E conseguimos pessoas para serem voluntárias, para dar aula pra gente. E foi muito legal esse momento porque criou uma nova consciência de que eles poderiam sim continuar sendo gordo, porém mantendo a vida saudável, não precisava emagrecer. Claro que com atividade física que o emagrecimento seria uma consequência, mas não seria o principal. O principal seria movimentar, movimentar o corpo, fazer as pessoas entenderem que mesmo sendo gordas nós poderíamos ter uma vida saudável

\footnotetext{
${ }^{8}$ Espaço público localizado no centro de Salvador onde é a comum a prática de atividades físicas ao ar livre.
} 
É necessário destacar aqui a importância das chamadas redes sociais de apoio. Segundo Rosa e Benício (2009),

“as relações sociais de apoio estão associadas à organização do vínculo entre pessoas e é composta pela rede de relações formais e informais. As relações formais seriam os contatos com profissionais como médico, dentista, professor, advogado, etc., e outras pessoas conhecidas. Por outro lado, as relações tidas como de maior importância pessoal e afetiva são as relações sociais informais, compostas por vínculos com todos os demais indivíduos (família, amigos, vizinhos, colegas de trabalho, comunidade, etc) e têm como características marcantes a familiaridade e a proximidade, com envolvimento afetivo.

Segundo as autoras, as redes sociais de apoio têm grande impacto na qualidade de vida e na saúde de grupos populacionais. Segundo as autoras, "as relações sociais de apoio estão associadas à organização do vínculo entre pessoas e é composta pela rede de relações formais e informais. As relações formais seriam os contatos com profisssionais como médico, dentista, professor, advogado, etc., e outras pessoas conhecidas. Por outro lado, as relações tidas como de maior importância pessoal e afetiva são as relações sociais informais, compostas por vínculos com todos os demais indivíduos (família, amigos, vizinhos, colegas de trabalho, comunidade, etc) e têm como características marcantes a familiaridade e a proximidade, com envolvimento afetivo." (Rosa e Benício, 2009)

Por meio do relato de Cecília sobre a criação do grupo de Facebook e posteriormente do ato da caminhada é possível apreender a importância da criação desses espaços de apoio para as entrevistadas que também funcionam como redes com as quais se conectam a experiências, vivências e dificuldades comuns.

Segundo as narrativas das entrevistadas, percebe-se uma enorme semelhança no engajamento das ativistas das fundadoras do movimento que denuncia, hoje, a gordofobia, isto é, o preconceito contra indivíduos que presumivelmente não se enquadram nos padrões de estética corporal socialmente hegemônicos. Antes da experiência da militância, onde foi possível conhecer pessoas com vivências parecidas, o posicionamento crítico em relação ao estigma do corpo gordo parecia não ser corrente. Certamente poderia haver incômodo em ter o corpo gordo numa sociedade que deprecia essa condição, tanto do ponto de vista estético como também pelo presumível risco à saúde, entretanto, ser o estigma de gorda não era algo problematizável politicamente. É por isso mesmo que Simone reage assim: Eu peguei amizade com uma menina, que, por acaso, estava em um grupo chamado "Gordinhas lindas da Bahia". Eu achava muito 
estranho. Me perguntava: "o que que essa menina quer? Ela tá maluca? Grupo de meninas gordas?!” É evidente que Simone sabia que era gorda, no entanto, ser gorda não se constituía num problema a ser pensado e abordado politicamente. A consciência de que ser gorda tem implicações estéticas, filosóficas e políticas só viria depois do engajamento em coletivo criado como espaço de reflexão. Para Lígia, o que a atraiu no início do seu engajamento foi o fato do grupo de mulheres gordas promover o "entretenimento": E a gente se conheceu através dos grupos do Facebook, de um dos grupos de entretenimento que o movimento administra, que é o Gordinhas Lindas da Bahia-Oficial..." Evidentemente que entreter não é um fim em si mesmo, mas promover a experiência de socialização mediante a utilização dessa estratégia era, possivelmente, o meio mais fácil para atrair essas mulheres que pareciam não ter uma consciência formada sobre o significado de ser gordo em nossa sociedade. As mulheres que iniciaram o movimento, rigorosamente, foram surpreendidas com a possibilidade que de que se condição de gordas interessava a outras pessoas. Carla foi recrutada de surpresa para ser integrante do futuro movimento: Assim, foi uma coisa bem inusitada, tava no hospital de acompanhante com minha avó, e aí tinha uma acompanhante do meu lado e ela falou "eu vou lhe colocar num grupo pra você passar o tempo enquanto você tá aqui no hospital". O recrutamento, como se pode perceber, além da surpresa, pegou a futura integrante fragilizada, por estar acompanhando sua mãe enferma. Nota-se também que a proponente oculta propositadamente o objetivo da abordagem - recrutar uma nova militante -, presumivelmente, para não assustar a moça que já estava sensibilizada com a doença de sua mãe. O movimento contra a gordofobia, Carla saberia depois, não tinha nada de passatempo, ao contrário, envolvia uma dimensão da vida social até então desconhecido para ela. Até mesmo Cecília, que iniciou o movimento e até hoje lidera com destaque, não tinha uma formação intelectual prévia sobre a importância do tema e tampouco planejara os rumos que tomaria a discussão mais tarde. Ela, como as demais lideranças, partiu de uma ideia muito simples do porquê era necessário reunir mulheres que tinham como algo em comum a gordura: ...eu não tinha nenhuma intenção de... que fosse o que é hoje, no caso, de ter a parte coletiva, não pensava nisso. Era realmente naquele momento, era realmente uma coisa de diversão mesmo, uma coisa estética, algo pra namoro mesmo, antigamente existia, baseado nessas coisas. Cecília identificava o fato de ser gordas era o traço de união dessas mulheres, porém, a intenção primária era a de elevar a autoestima, construir espaço nas relações sociais para serem aceitas 
socialmente. Buscar namorar é lutar ser aceita pelo outro. Nesse sentido, portanto, essas mulheres eram consideradas vítimas da condição de serem gordas.

No decorrer da constituição do movimento contra a gordofobia, outras pautas foram acrescidas ao discurso central de valorização do corpo, motivados pelos recortes de gênero, raça e classe social. São recortes reveladores do local social de fala dessa militância. Pode-se afirmar que o grupo referido é marcado pelos recortes de gênero, raça e classe social. São recortes fundamentais para compreender a atuação do mesmo enquanto militância. Palavras como sobrevivência, acessibilidade, saúde, emprego, estão no centro do discurso do grupo, que, em muitos momentos, ressaltam a diferença entre essa perspectiva e uma classificada como "midiática", onde a preocupação é apenas "estética". As dimensões sociais e raciais enfatizam a importância de entender que a luta contra o preconceito da obesidade está conectada a outras dimensões que caracterizam o grupo no contexto social. Segundo Crenshaw (2002), as discriminações racial e de gênero operam em conjunto, limitando as chances de sucesso da mulher negra. Segundo a autora, os a gentes do Estado devem reconhecer o que ela chama de intersecionalidade das discriminações, afim de que políticas públicas possam contemplar os diversos grupos sociais. Essa é a razão pela qual as integrantes do movimento dirigirem suas reivindicações ao Estado, que é ente responsável por implantar políticas públicas, o que é bem diferente da perspectiva inicial quando essas mulheres se sentiam culpadas por serem gordas.

A participante Lúcia, 38 anos, faz da yoga, que é uma filosofia de vida e uma prática específica de cuidar do corpo e da mente, seu campo de militância. Natural de São Paulo, branca e oriunda de família de baixa renda, Lúcia largou seu trabalho na área de comércio exterior para poder trabalhar com a yoga.

Eu falava: "O que eu to fazendo aqui? O que eu to fazendo num lugar que eu não acredito, com um trampo que eu não acredito, com pessoas que eu não acredito? Eu vi na Yoga essa oportunidade, porque eu lembro que quando eu comecei a praticar lembro, eu falava: 'Cara, eu não vou fazer, eu sou gorda, como é que vou fazer Yoga?' Porque o que é vendido pra gente é esse recorte de classe mesmo, esse recorte estrutural que é branco, magro, hétero e rico faz yoga. Outras pessoas não fazem. Eu não tava ali sendo uma pessoa gorda. Quando eu fui fazer eu fiz a porra toda, sabe? Falei: “Como assim?”. Então, eu queria primeiro a Yoga, porque ela realmente faz diferença na vida das pessoas, eu consigo ver uma mudança porque foi o que mudou a minha e acaba sendo um ato político mostrando o corpo. 
Lúcia afirma que não faz parte de nenhum grupo organizado, porém, além da sua atuação no projeto chamado Yoga para todos, ela participa na organização de uma feira de moda chamada Pop Plus. De acordo com o site do evento, o Pop Plus é "uma feira de moda e cultura plus size que acontece quatro vezes por ano em São Paulo: março, junho, setembro e dezembro. Sua primeira edição foi em dezembro de $2012 \mathrm{com}$ 9 expositores. Sua edição mais recente, em dezembro de 2018, contou com 90 expositores e um público de cerca de 18 mil pessoas. Na essência do Pop Plus estão a moda como identidade e dignidade, diversidade, representatividade, fortalecimento do empreendedorismo feminino, busca da autoestima e o respeito ao próximo" 9

Já Tereza, 31 anos, também de São Paulo, branca se encaixar no que Cooper chama de Micro fat activism e acvtivist communities. Sua militância está ligada, principalmente, à redes sociais, onde divulga e debate temas da militância gorda. Segundo Tereza,

Hoje a minha militância tá mais militância de internet, mas eu já tentei fazer alguns grupos ao vivo, com a Lúcia, inclusive. Não rolou muito certo. Mas eu sou uma pessoa gorda desde sempre, desde que eu me conheço por gente e ao poucos eu fui descobrindo, conforme a internet foi evoluindo e as pessoas começaram a se juntar, fui descobrindo que existiam outras pessoas gordas como eu, em lugares diferentes dos país às quais eu tinha algum acesso, que sofriam mais ou menos as mesmas questões que eu e, especialmente, que sofriam muito psicologicamente e que tinham muitos problemas vindos dessa vivência gorda e fui me juntando a elas. Então, hoje, basicamente, eu uso as redes sociais, já tentei usar vídeo, mas não deu muito certo, uso Instagram, meu perfil no facebook e uso alguns grupos de visibilidade pra conversar com pessoas gordas de outros lados, que não estejam tão perto de mim pra tentar compartilhar vivência e, a partir desse compartilhamento de vivências, melhorar um pouquinho a vida das pessoas e a minha também

\subsection{Gordas, gordinhas e plus size}

Um ponto em comum entre todas as entrevistadas, que também é comum na militância como um todo, é a utilização da palavra gorda para referir a si próprias. No primeiro roteiro de perguntas havia um item que buscava discutir a categoria "gorda",

\footnotetext{
${ }^{9} \mathrm{https}: / /$ popplus.com.br/sobre-o-evento/
} 
buscando chegar em um conceito mais preciso do mesmo. Porém, essa definição de gorda se mostrou complexa, não existindo, aparentemente, consenso sobre ela.

Assim, a definição mais utilizada é a questão do corpo, quem é gordo, que não é gordo é quem veste acima de 38. (...). Quem veste 38 é que está no padrão, acima de 38 já é, como é que eu poderia dizer... claro que esse termo chega a ser ridículo, um pouco mais cheinha, como as pessoas falam. Ai acima do 46 eles dão a definição de plus size, quem veste acima de 46 é plus. E aí esse plus vai até 52, parece. E isso depende muito de quem esteja falando, porque tem algumas lojas que colocam plus size até o número 60. Outras até 50. Mas verdadeiramente a moda plus size ela não é pra pessoa gorda. Que tem, eu não consigo comprar uma roupa plus size, porque é sempre muito apertado, é menor do que eu, e eu nem sou a mais gorda do grupo. Imagina pra quem veste 60, a dificuldade de tá comprando, e aí o que acontece é fazer essa definição. (Carla)

Perguntada sobre a diferença entre "gorda" e "gordinha", Simone afirma: Eu acho que é a estrutura do corpo mesmo... a estrutura do corpo gordinha é uma menina que engordou um pouquinho, né? Que tem um pouquinho de barriga, que tem um pouquinho de peito, e eu não... eu sou gorda, minha barriga é grande, sabe? Eu conheço umas meninas que tem os peitos maiores... e tem... e também... tudo muito fora do... daquele outro padrão, né?

Essa gradação entre diferentes tipos e medidas de ser gorda, como diz a entrevistada, a estrutura do corpo gordinha é uma menina que engordou um pouquinho, ao mesmo tempo em que dificulta o estabelecimento de parâmetros precisos para o uso da militância, termina por reforçar o discurso biomédico que estabelece padrões quantitativos, isto é, fórmulas matemáticas que definem para cada um quem é gordo. Esses requisitos reforçam a influência do discurso científico pela sua reconhecível força e legitimidade social. Canguilhem (2009) interroga se a patologia seria apenas uma "variação quantitativa do estado normal". A inexistência dos mesmos parâmetros pela militância prejudica a capacidade de convencimento dos seus discursos. A tese da militância é que apesar da maioria das pessoas se sentirem inadequadas com o próprio corpo e, de alguma, forma, sofrerem com isso, apenas as pessoas gordas sofrem opressão. Existe, inclusive, uma categoria nativa que separa os dois casos, o da pressão estética. Sobre esse ponto, Tereza comenta 
Outro momento que ela fala, ainda hoje, que disse merda foi quando eu comecei a conversar com ela sobre essa ideia da diferença entre pressão estética e gordofobia. Não é porque toda mulher sofre com a pressão estética que isso se compara ao que uma pessoa gorda sofre e mesmo a pressão estética que uma pessoa gorda sofre é muito maior do que a mulher sofre.

As entrevistadas ressaltaram a diferença política e das possibilidades de inclusão social entre "gorda" e "plus size". Sobre as diferenças, Lígia e Cecília afirmam que Quando existe uma militância plus size, midiática, estética, padronizada e por outro lado uma militância gorda que milita em prol da sobrevivência. Carla questiona o sentido da noção de "plus size": Mas, pra nós, a gente vê o plus size como uma forma de ganhar dinheiro da pessoa gorda. Já Simone esboça uma definição de "plus size" e "gorda": distante até do padrão que é estabelecido plus size, que você sai daquela magreza, mas tá gordinha, que tem um pouquinho de peito, que tem um pouquinho de coxa, que tem um pouquinho de bunda. (Lígia)

E a militância plus size, que é a parte do glamour, a parte onde as pessoas trabalham o ego mesmo, onde as pessoas... buscam reconhecimento por algo estético, mesmo, e... e existe a militância, o movimento mesmo, o movimento de militância, o movimento social, que busca políticas públicas, direitos, o empoderamento... ambas buscam o empoderamento da mulher gorda, mas de formas diferentes. Repara-se que dentro do movimento plus size existe um empoderamento falso. São mulheres que usam o corpo para a parecer, para ganhar fama e glamour. E nem sempre esse corpo gordo faz elas, nem sempre elas gostam de ser mulheres gordas. São gordas porque está na moda. E a gente na militância, na parte social, a gente busca uma coisa mais completa, porque não adianta a gente tá na televisão, tá na passarela, eu tá na revista e chegar em casa e meu corpo ser uma prisão. (Cecília)

Para Tereza, que acentua a tensão entre as identidades plus siza e gorda, plus size seria apenas uma maneira de atenuar sua identidade de mulher gorda:

outro dia um amigo do meu namorado. Aí, ele contou pro amigo dele que ele tava namorando, ai a primeira coisa que ele falou foi que eu era ruiva, disse: "Ela é linda, maravilhosa, deixa eu te mostrar uma foto". Então, o amigo disse: "Nossa, ela é muito bonita mesmo. Ela é plus size”. Aí, eu achei muito engraçado porque o Lucas virou pra ele e falou: "Não, amigo, ela é gorda". Aí, ele ficou meio sem graça. Pra eu mesma 
chegar nesse nivel demorou muito tempo. Eu tinha bem clara essa coisa de que eu era gorda e gorda era uma das piores coisas que eu poderia ser.

Para as militantes do Movimento Gordo da Bahia, o sentido de militância plus size têm múltiplos e negativos significados: são as pessoas que, segundo elas, se aproveitam das conquistas da militância gorda para autopromoção, focando apenas não questão estética do ser gorda; não são, muitas vezes, mulheres gordas "de verdade"; são mulheres de uma classe social mais privilegiada; são mulheres brancas. Como se pode observar, retomando o que foi observado anteriormente, a luta contra a gordofobia fazem uma intersecção com as dimensões social e de raça e aparecem com frequência na fala das militantes de Salvador:

E essa dificuldade de ser mulher gorda e negra. Que é uma dificuldade maior, porque quando você é uma mulher gorda e branca, você é da moda plus size, quando você é mulher negra e gorda você não faz parte de nada. (Simone)

E... existe essa parte desse recorte da militância negras, sim, pra mulheres brancas, sim, porque infelizmente o racismo está aí, em todos os lugares e são coisas diferentes, dificilmente você vai ver uma mulher negra, uma mulher gorda e negra, como miss plus size. Até temos uma mulher negra, porém não é uma negra retinta, é uma negra com pouca melanina. E esses movimentos, esses concursos não chegam às periferias. Porque são caros. Acaba de uma forma ou de outra segregando as pessoas, porque a maioria das mulheres gordas são mulheres desempregadas, independente se elas tenham qualificação. Então existe esse recorte sim, existe uma divisão no movimento sim, sobre ter ou não ter mulheres negras em determinadas porções, dificilmente a gente vai ver nas revistas, na televisão, como miss. A gente procura fazer dentro das comunidades, buscar essas mulheres, que muitas das vezes se escondem, tem vergonha de sair... tem mulheres que nunca ouviram falar o que é gordofobia, e a gente tenta levar para essas pessoas esse conhecimento. (Cecília)

A fala de Cecília toca num dos pontos mais importantes no debate sobre a gordofobia: o recorte de classe e raça. Hoje, o número de pessoas classificadas como obesas só cresce em países desenvolvidos e em desenvolvimento e, em especial, nas camadas mais pobres da população (Ferreira e Magalhães, 2010; Lee et al 2014). Um dos efeitos da estigmatização do corpo gordo é a dificuldade que essas pessoas tem em 
encontrar trabalho. O que, associado ao racismo, torna essa cenária ainda pior. O que se tem, então, é um cenário onde o acesso à alimentação para pessoas pobres é extremamente precarizado, pois baseada principalmente em alimentos ultraprocessados ${ }^{10}$, que deterioram a saúde dessa população e faz com que elas ganhem peso. Esse "excesso" de peso, por sua vez, faz com que as pessoas encontrem dificuldade em conseguir trabalho, são avaliadas do ponto de vista estético negativamente e terminam sendo discriminação por serem gordas, condição que muitas vezes repercutem dramaticamente na inclusão social, sobretudo das mulheres e das mulheres negras mais acentuadamente, e com isso, acarretando impactos psicológicos e psiquiátricos sérios.

\footnotetext{
${ }^{10}$ Segundo Menegassi et al (2018), "Alimentos ultraprocessados são formulações industriais prontas para consumo e feitas inteira ou majoritariamente de substâncias extraídas de alimentos (óleos, gorduras, açúcar, amido, proteínas), derivadas de constituintes de alimentos (gorduras hidrogenadas, amido modificado) ou sintetizadas em laboratório com base em matérias orgânicas como petróleo e carvão (corantes, aromatizantes, realçadores de sabor e vários tipos de aditivos usados para dotar os produtos de propriedades sensoriais atraentes)"
} 


\section{Capítulo IV - CORPO E SAÚDE}

\subsection{Medicalização da obesidade}

Argumentando pela complexidade existente nas diferentes dietas humanas, o filósofo Michel Onfray afirmou que "não existe dietética inocente". Tomando por empréstimo o sentido dessa frase, pode-se afirma que não existe também patologia inocente. $O$ saber biomédico sobre doença não é um dado da "natureza". A doença, no contexto da biomedicina, também é uma construção social. Como tal, ela é portadora de significados culturais múltiplos (Conrad e Barker, 2010). Segundo Breton (2016), é preciso interrogar a instituição médica e a visão de corpo que ela produz, assim como, faz-se necessário interrogar também o processo de construção dos sentidos de saúde e doença pela biomedicina.

A representação moderna de corpo nasce com os primeiros anatomistas, e em especial na obra De humanis corpore fabrica, de André Vesalius. A partir desse momento, surge uma nova episteme ocidental sobre o homem e seu corpo. O homem, nesse contexto, é cindido de si mesmo: nasce o dualismo corpo x homem. A representação de um corpo holista é abandonada em favor de uma visão que busca estudar o corpo separado do homem. É nessa percepção de homem que a biomedicina sustenta sua prática. "Um corpo cindido do homem, tornado leve, percebido como receptáculo da doença.” (Breton, 2011: 222).

Partindo dessa visão de homem, o humano e seu corpo são apresentados aos estudantes da biomedicina de maneira fragmentada. Nas aulas de anatomia não se tem contato com uma figura humana completa, mas sim com "peças" (corpo-objeto). Só mais tarde, na entrada clínica, que pessoas reais (corpo-pessoa) passam a fazer parte do aprendizado (Russo; Souza e Pitanguy, 2006). Segundo Russo (2006), a prática biomédica depende de algum grau da objetificação do ser humano, o que pode ser verificado nos cursos de formação em medicina, cujo enfoque primeiro está no "corpoobjeto", corpo anatômico dos estudos. Todavia, a passagem do corpo-objeto para o corpopessoa é também necessária ao aprendizado dos estudantes de medicina e biomedicina, embora não aconteça nos primeiros anos de curso. Como argumenta a autora, a medicina moderna científica buscou, em seu desenvolvimento, transformar corpos pessoa em corpos objetos. A autora demonstra a impossibilidade desse intento, bem como a necessidade de uma articulação entre essas duas dimensões. 
O corpo gordo, a partir dessa concepção fragmentada de corpo, é, de longa data, objeto de interesse da humanidade. E os significados atribuídos a ele, variados. Embora a percepção negativa de corpo (corpo doente, pecado da gula, descontrole de si) hegemônica em relação à gordura corporal seja relativamente nova, a noção muitas vezes repetida pelo senso comum que no "passado" o corpo gordo possuía apenas significações positivas (corpo saudável, status de riqueza) é equivocada. As significações acerca da gordura corporal têm uma história complexa, passando pela arte, medicina, religiosidade, política, dentre outras dimensões sociais.

Corpos gordos são representados em artefatos desde a Idade da Pedra, como na famosa escultura encontrada na Áustria, a chamada Vênus de Willendorf. No Período Neolítico, que marcou o início da agricultura, outro grande número de estatuas representando figuras gordas também surgiram. No Egito Antigo, esculturas em relevo também apresentavam representações de corpos gordos. (Bray, 2009: 3). Como referido anteriormente, a noção de que gordura corporal era, num passado próximo, sinônimo de saúde é bastante corrente no senso comum. Porém, a correlação entre corpo gordo e doença remonta à Idade Antiga. Segundo Bray (2009: 3), o corpo gordo e suas consequências fazia parte de tradições médicas em diversas culturas. Na Grécia Antiga, associações entre males da saúde e corpo gordo já eram feitas pelo médico grego Hipócrates, que afirmou que morte súbita era mais comum nas pessoas gordas do que nas pessoas magras (Bray, 2009: 3). Quinhentos anos após Hipócrates, surgiu com o médico romano Galeno um dos primeiros casos de controle do peso corporal. Galeno afirmou que conseguiu reduzir a gordura corporal de um indivíduo com uma prescrição de dieta e atividade física. No Egito antigo também já existia a prática de dietas e jejuns com propósito de preservar a saúde (Haslam, 2006: 32). Ainda segundo Bray (2009: 5-6), um tratado médico hindu datado do século XVII reconhecera o corpo gordo como uma condição passível de tratamento através da perda de peso. Esse mesmo tratado afirma que comer demais era fator para a mortalidade.

Porém, até se tornar hegemônico, o discurso biomédico sobre o corpo gordo "compete" com outros discursos, como o religioso, por exemplo. Segundo Vigarello (2012: 9-15), a história do corpo gordo e dos discursos sobre ele é ambivalente. Num mesmo período o corpo gordo podia representar poder e fartura tanto quanto preguiça e gula. Além disso, as definições médicas sobre o que é gordura e sobre quem é gordo até o século XIX ainda eram controversas: "É que a gordura ainda é matéria obscura na medicina clássica - uma substância que, à revelia de toda química, sugere referências 
intuitivas, senão opostas, mesclando divergências e obscuridades." (Vigarello, 2014: 92). A mesma polêmica pode ser identificada quanto a definição de quem é gordo. Embora conceitos como "gordo" e "muito gordo" apareçam, antecipando conceitos como "sobrepeso" e "obesidade", eles são determinados de maneira mais intuitiva do que objetiva (Vigarello, 2014).

As entrevistadas desta pesquisa foram instigadas a falar sobre a relação entre corpo gordo / doença e o que define alguém como "gorda(o)". Sobre a questão do corpo gordo e da sáude, Cecília afirma:

"E aí um médico renomado de são Paulo, ex-gordo, segundo ele(...): 'Não, mas as vezes suas taxas estão todas normais, mas você está doente'. Eu fiz... então como é o que eu vou saber? Como é isso? Porque a gente sabe quando tá com a saúde em dia quando as taxas que são pré-estabelecidas, durante anos, durante toda a vida, a gente, é aquilo ali... e de repente ele vira pra gente e diz "não, suas taxas estão em dias, tão tudo certinhas, tá tudo ali. Mas você está doente.". Sabe? E isso assusta."

A fala de Cecília remete diretamente a uma das principais controvérsias da chamada doença obesidade: existe doença quando o corpo gordo não apresenta nenhuma comorbidade ${ }^{11}$ ? Ora, o discurso do médico é ambíguo. A sua preocupação médica não está centrada na identificação de uma possível doença e o tratamento mais adequado a partir dos exames realizados constatarem indicadores ou taxas adequadas ou não ao quadro de saúde da paciente. Pelos resultados dos exames realizados da entrevista, a gordura corporal da paciente, pelo menos naquele caso, não parecia ser, segundo sua percepção, um fator importante para o desequilíbrio de sua saúde. Mas, para a surpresa dela, a conclusão médica "assusta": os fundamentos do diagnóstico estão compatíveis com um quadro de boa saúde, mas a paciente está doente. Ou seja, a gordura é uma doença em si mesma. Com essa conclusão médica a paciente pode nem estar doente, o que aparentemente foi atestado pelos exames, o que não se pode prever é o impacto psicológico e fisiológico nessa paciente após o laudo, já que a força simbólica do discurso médico nas sociedades contemporâneas é, muitas vezes, determinante para a cura ou o adoecimento.

O processo de medicalização do corpo gordo nos revela uma longa e complexa trajetória que culmina na patologização de um certo tipo de corpo através de medidas

\footnotetext{
${ }^{11}$ Quando ocorre duas doenças simultâneas e relacionadas
} 
corporais. Em diferentes autores e com diferentes terminologias, o tema da medicalização tem sido recorrente nas ciências humanas (Nye, 2003). Nesta dissertação será usada a definição proposta por Peter Conrad (2007; 1992). Segundo Conrad (2007), as ciências humanas têm se interessado pelo tema da medicalização desde o final da década de 60 . Inicialmente os estudos se concentraram na medicalização do desvio ${ }^{12}$, mas logo em seguida (início dos anos 70) os estudos sobre medicalização começaram a se interessar em como as mais diferentes experiências e comportamentos humanos passaram a fazer parte da "jurisdição" da biomedicina.

Medicalização é o processo pelo qual questões não médicas passam a ser definidas e tratados pela medicina. De forma mais específica, a medicalização é um processo sociocultural onde um problema é definido em termos médicos, usando uma linguagem própria da medicina para descrevê-lo e adotando-se uma abordagem médica para tratá-lo. Frequentemente o conceito de medicalização tem sido usado como uma crítica às práticas médicas vigentes, investigando como esse processo, nas mais variadas áreas, afeta a vida dos sujeitos. Porém, o que se busca nesses estudos não é questionar se determinadas experiências e comportamentos humanos são ou não questões médicas. A questão é perceber a medicalização como uma "entidade" em si (Conrad, 1992; 2007).

A medicalização abrange um largo espectro de experiências e comportamentos humanos, incluindo-se nela os chamados desvios, como alcoolismo, transtornos mentais e transtornos alimentares. Também eventos fisiológicos e psicológicos comuns como menstruação, mudanças de humor, parto, envelhecimento e menopausa. Porém, há graus de medicalização. Enquanto eventos como o parto pertencem hegemonicamente à “jurisdição" da medicina, outros como a menopausa são "parcialmente" medicalizados (Conrad, 2007). A medicalização é “bidirecional”, no sentido que alguma questão pode deixar de ser medicalizada. A homossexualidade, por exemplo, só deixou de ser oficialmente desmedicalizada em 1970 (Conrad, 2007). Isso significa dizer que o processo de medicalização está vinculado estreitamente a uma legitimidade social atribuída em cada época.

Segundo Xello (2014), a partir do século XIX se inicia uma ascensão dos números para definição dos corpos. Antes do estabelecimento da relação entre peso x altura, medidas como circunferência e volume aparecem como medida dos corpos. Porém, a introdução, em 1885, de uma balança com precisão próxima de $1 \mathrm{~kg}$ possibilitou as formas

\footnotetext{
${ }^{12}$ Segundo Conrad e Schneider (1992), o desvio é definido como ações ou condições que violam as convenções sociais de determinados grupos que detém algum tipo de poder.
} 
de avaliação que existem hoje. Antes do Índice de Massa Corporal (IMC) se estabelecer como norma na avaliação da obesidade, outras formas de medição existiam. Segundo Komaroff (2016), uma das maneiras de medir a obesidade é comparar o peso de um indivíduo com um valor de referência, que seria a média do peso de uma população. Uma outra maneira é comparar um intervalo de peso e sua relação com mortalidade e morbidade. Porém, foi com o matemático e astrônomo belga Adolph Quételet (1796 1874) que o IMC começou a ser elaborado. Quételet buscava uma noção de norma ou média do corpo humano. Para isso, ele elaborou um índice que é resultado do peso de um indivíduo dividido pelo quadrado de sua altura. $\mathrm{O}$ intervalo de valores médio encontrado num estudo populacional feito por Quételet, é o que veio a ser chamado por ele de "homem médio". Porém, esse índice ainda não tinha como objetivo dizer qual seria o peso ideal ou saudável (Bray; Williams e Frühbeck, 2009).

Para diversos autores (Poulain, 2013; Bray, 2009; Komaroff, 2016; Truswell, 2013), o conceito de peso ideal e a consequente correlação entre o que estava fora do ideal e problemas de saúde se estabeleceu a partir de estudos das companhias de seguro de vida dos Estados Unidos. Dados de pesquisa de diversas companhias de seguro de vida apontavam para relação entre um IMC acima da média e o risco de morte prematura. Posteriormente, outros estudos epidemiológicos corroboraram com essa mesma associação.

Porém, o IMC como método hegemônico de avaliação a obesidade só se estabeleceu no final da década de 1990, a partir de recomendação da Organização Mundial de Saúde (OMS). Segundo Poulain (2013), o IMC se estabelece como método dominante pela sua praticidade, baixo custo de avaliação e suposta capacidade de fazer predições relacionadas a mortalidade. Pesquisas epidemiológicas passaram a estabelecer, ao longo da década de 1990, relações entre mortalidade, principalmente cardiovascular, e intervalo de valores do IMC. Segundo Bray e Bouchard (2004), o IMC tem uma relação curvilínea em relação a problemas de saúde. O que significa dizer que existe um intervalo de valores onde os riscos são menores, o chamado de IMC normal. E esse intervalo é precedido e seguido por intervalos de riscos mais altos a saúde. Posteriormente, categorias que definiam os valores do IMC que se relacionavam com normalidade e doença foram sendo criadas. Em 1995, a OMS publicou os intervalos de valor do IMC onde normalidade e doença poderiam ser definidos. Abaixo de 25, são valores considerados como saudáveis. Entre 25 e 29.9, preobeso e acima de 30, obeso. Entre obesos, ainda é possível verificar a classe I (30-34.9), classe II (35-39.9) e classe III (acima de 40). 
Posteriormente, em 200, a OMS define a obesidade como a doença na qual um excesso de gordura corporal se acumulou de maneira tal que a saúde pode se tornar afetada." (Tradução livre) $^{13}$. (Komaroff, 2016: 7).

Segundo Poulain (2013: 172-173), durante muito tempo a obesidade era apenas considerada um fator de risco. Em 1990, a partir da entrada no CID (Classificação Estatística Internacional de Doenças e Problemas Relacionados com a Saúde) a obesidade é “oficialmente" reconhecida como doença.

Após ser reconhecida como doença, a obesidade ainda passa por mais uma mudança de estatuto, o de epidemia. O termo epidemia começou a ser utilizado após a divulgação de um relatório da OMS chamado Obesidade: prevenção da epidemia global, que afirma:

Hoje, no entanto, enquanto os padrões de vida continuam a subir, ganho de peso e obesidade estão se tornando uma crescente ameaça à saúde em diversos países no mundo. Obesidade é uma doença crônica, que prevalece em países desenvolvidos e em desenvolvimento, afetando crianças e adultos. Em verdade, é tão comum agora que está substituindo preocupações tradicionais da saúde pública, como subnutrição e doenças infectocontagiosas como uma das mais significantes ameaças a saúde. ${ }^{14}$. (WHO, 1999)

Ainda segundo Poulain (2014), o surgimento do termo epidemia tem papel fundamental na globalização da questão da obesidade e, posteriormente, no empreendimento da chamada guerra à obesidade.

Vê-se que a definição de um índice ideal de peso corporal envolve: preocupações estritamente médicas, de políticas públicas para a saúde global, especulações sobre o corpo ideal - o que pode estar incluído inclusive uma representação legítima de corpo adequado a estética de cada contexto histórico - e interesses fundamentalmente capitalistas, como os que preocupam os proprietários das seguradoras.

Dessa forma, é possível afirmar que para a biomedicina hoje, o chamado corpo obeso é doente. Desafiando essa noção, a entrevistada Simone afirma:

\footnotetext{
13 Original: "the disease in wich excess body fat has acumulated to such an extent that health may be adversly affected"

${ }^{14}$ Original: "Today, however, as standards of living continue to rise, weight gain and obesity are posing a growing threat to health in countries all over the world. Obesity is a chronic disease, prevalent in both developed and developing countries, and affecting children as well as adults. Indeed, it is now so common that it is replacing the more traditional public health concerns, including undernutrition and infectious disease, as one of the most significant contributors to ill health."
} 
“É... assim, o grupo da gente fica tentando, a gente não sabe ainda como ou se vai conseguir, a médio e longo prazo, tentando tirar (...) a obesidade, o corpo gordo como doença, né? Na verdade, não tem problema nenhum."

É recorrente na fala de Simone e de outras entrevistadas a noção de que uma pessoa não pode ser considerada doente apenas pelas medidas que seu corpo apresenta. A tentativa de desnaturalização do conceito de corpo gordo como expressão de doença, posição militante defendida por Simone e Cecília, podem levar a crer que existe uma hegemonia, entre as militantes, dessa forma de encarar o corpo gordo. Porém, existe uma disputa quanto ao uso do conceito de obesidade, como é possível identificar na fala de Lígia:

"Não podemos romantizar a questão da saúde, porque quando se romantiza a saúde da pessoa obesa, porque para termos de saúde o correto é usar o termo obeso. Muita gente tem preconceito, assim. Até as pessoas que militam na área gorda de usar esse termo, mas na área de saúde a morbidade é a obesidade, então tem que ser usado esse termo."

Em outro momento da entrevista, Lígia complementa esse raciocínio sutil de abordar o problema:

“ (...) mas falando de uma realidade sem romantizar a doença da obesidade, da pessoa obesa. Eu tenho amigas que são gordas, mas não são obesas porque não tem patologia nenhuma. A sociedade enxerga elas como obesa porque o corpo delas é um corpo gordo."

Para Lígia, só pode ser considerada obesa uma pessoa gorda que carrega alguma comorbidade, caso contrário, ela é apenas gorda. Quando fala em "romantização" da dimensão da saúde envolvida na discussão sobre a gordura. Essa dissidência é reveladora também de que o discurso da medicalização do corpo tem um peso considerável, inclusive entre as militantes que se opõem supostamente às representações hegemônicas sobre o corpo, notadamente o corpo feminino que, possivelmente, é o mais tensionado em virtude do machismo presente na sociedade que cobra com mais ênfase o ideal de "corpo perfeito”. Uma outra entrevistada, Carla, faz análise parecida a de Lígia: “(...) porque na verdade... tem algumas pessoas que fantasiam essa questão. A gente não quer contar vantagem, a gente não quer fantasia de que ser gordo é saudável, em nenhum momento. Mas que a gente tenha, seja gordo, uma qualidade de vida melhor.". 
Apesar da aparente divergência, fica claro um ponto fundamental de concordância entre as duas entrevistadas: é possível ter um corpo gordo e ter saúde. Dentro do campo biomédico, essa concepção é defendida por alguns de seus atores. Essas vozes dissonantes se orientam por diversos pontos de vistas, como o biomédico, o político, o psicossocial e o da moralidade. As controvérsias biomédicas, que se orientam através dessa concepção, questionam o atual status da obesidade, enquanto doença e epidemia, através da mesma linguagem biomédica que a valida. Do ponto de vista político, é explorada a relação entre o fortalecimento do atual status da obesidade e forças econômicas, como planos de saúde, indústria farmacêutica, etc. Já as controvérsias psicossociais enfatizam os efeitos que o atual status da obesidade podem ter sobre a vida emocional e social dos indivíduos; como a crescente estigmatização dos ditos obesos impacta na saúde dos mesmos. Sobre essa questão, Cecília afirma:

"E a maioria das pessoas gordas não são doentes apenas... muitas não são doentes fisicamente, mas são doentes psicologicamente. E o corpo começa a adoecer por conta dessa doença psicológica. É aí que eu tenho medo."

Segundo Basham e Luik (2008), a ideia de que existe uma epidemia de obesidade é exagerada. Os autores argumentam que ideia de determinar uma expectativa de vida normal é complexa em si mesma e, também, que a determinação de categorias normal, sobrepeso e obesidade são arbitrárias. Basham e Luik afirmam que dados atuais vão de encontro ao status de epidemia da obesidade:

Ademais, os dados atuais são altamente questionáveis na sua alegação de uma epidemia. Por exemplo, o ganho médio de peso nos EUA nos últimos 42 anos é de $10.0 \mathrm{~kg}$ ou $0.26 \mathrm{~kg}$ por ano. Ainda assim, entre 1999-2000 e 2001 e 2002, de acordo com o National Health and Nutrition Examination Survey, não existiu mudança signativa na prevalência de obesidade ou sobrepeso entre adultos ou a prevalência de sobrepeso entre crianças. ${ }^{15}$. (Basham e Luik, 2008: 1)

Glenn A. Gaesser, professor de medicina da Universidade de Virginia e autor do best seller Big Fat Lies, também questiona os males associados à obesidade. No artigo

\footnotetext{
15 Original: Moreover, current data are highly equivocal in their support for claims of an epidemic. For example, the average population weight gain in the US in the past 42 years is $10.9 \mathrm{~kg}$ or $0.26 \mathrm{~kg}$ a year. 4 Yet, between 1999-2000 and 2001-2002, according to the National Health and Nutrition Examination Survey, there were no significant changes in the prevalence of overweight or obesity among US adults or in the prevalence of overweight among children
} 
intitulado Is Weight Loss the Answer, Gaesser afirma que a perda de peso entre pessoas na faixa do chamado sobrepeso não aumenta a longevidade. Segundo o autor, as comorbidades associadas a obesidade podem ser melhoradas sem que exista redução do peso corporal. Para Gard e Wright (2005), o problema da obesidade é "uma salada de ciência, moral e de pressupostos ideológicos". Para esses autores, a difusão de expressões como epidemia da obesidade tem impacto nos campos emocionais e sociais dos indivíduos. Gard e Wright (2005) não contestam os males associados à obesidade, porém questionam os aspectos morais e ideológicos no tratamento biomédico da questão e como isso influencia diretamente em aspecto psicossociais da população.

Em The Politics of Pathology: How Obesity Became an Epidemic Disease, o cientista político Eric Oliver afirma que existe um problema fundamental na classificação da obesidade como uma patologia: a falta de evidências de que gordura corporal, em si, causa malefícios à saúde. Segundo o autor, embora em alguns casos extremos de obesidade, onde a capacidade de se locomover dos indivíduos fica comprometida, para a maior parte da população considerada obesa, não existe evidência de que a gordura corporal, por si só, cause algum dano à saúde. Ainda segundo o autor, a "criação" de uma epidemia da obesidade é motivada por interesses econômicos:

A ideia de que um certo tipo de peso corporal deve ser classificado como "doença" não é guiada por nenhum fato médico claro; em verdade, a pressão por classificar a obesidade como doença vem de um espectro de interesses, de alta e pequena relevância, através do espectro de cuidado à saúde. Médicos que advocam a perda de peso usam o modelo de doença para promover seus negócios: uma vez que você classifica pessoas gordas como "doentes", é fácil convencer elas e suas seguradoras que elas precisam de tratamento e medicação. Agências de saúde do governo, como o $\mathrm{CDC}$, estão constatemente pressionados por seu orçamento e sustentam para seus "clientes" primários (Congresso) que um realocação orçamentária é necessária para encarar um problema de saúde real ${ }^{16}$. (Oliver, 2006: 618)

Oliver ainda argumenta, com a m esma radicalidade anterior, que a "cura" da obesidade se tornou o "Santo Graal" da indústria farmacêutica.

\footnotetext{
${ }^{16}$ The idea that a certain body weight should be classified as a "disease" is not driven by any clear medical facts; rather, the pressure to label obesity a disease comes from a range of interests, from high to lowminded, across the health care spectrum. Weightloss doctors use the disease model to promote their business: once you can label fat people as "sick," then it is easy to convince them and their insurers they need treatment and medication. Government health agencies, such as the CDC, are under continual budget pressure, and they sustain their budget allocations by convincing their primary "customer" (Congress) that the nation has a real health problem
} 


\subsection{Violência institucional e o estigma da obesidade}

Segundo Aguiar et al (2013), a violência institucional pode ser entendida pela articulação dos conceitos de violência, autoridade médica e poder. Utilizando o conceito em Marilena Chauí, Aguiar et al (2013: 2288), afirma que violência é:

“(...) a transformação de uma diferença em desigualdade numa relação hierárquica com o objetivo de explorar, dominar e oprimir o outro que é tomado como objeto de ação, tendo sua autonomia, subjetividade, comunicação e ação livres impedidas ou anuladas."

Essa violência, no campo da saúde, é exercida de maneira verticalizada na relação entre profissional / paciente, onde o profissional se encontra no topo dessa hierarquia. Dentre os profissionais, o médico é quem detém a maior autoridade tecnocientífica sobre o corpo. Essa autoridade, legitimada pelo prestígio social e simbólico que o saber tecnocientífico possui, é a fonte de poder dos médicos (Aguiar et al, 2013). Citando Starr e Arendt, Aguiar et al (2013: 2289) afirma que "a autoridade é uma faculdade que suscita a confiança no outro e a obediência voluntária porque pressupõe a liberdade dos sujeitos envolvidos.".

A violência institucional é aqui entendida como uma relação de dominação, opressão e exploração de atores da instituição biomédica para com aqueles que ela atende. Há uma relação hierárquica que se assevera, sobretudo, em grupos estigmatizados. Segundo Goffman (1988), o estigma é um atributo depreciativo, que não é em si mesmo ruim, mas que diferencia o indivíduo estigmatizado perante o outro, o normal. $\mathrm{O}$ estigma pode ser uma "abominação do corpo" (peso corporal, deficiência física, altura etc.), pode ser um comportamento considerados como desviante (alcoolismo, homossexualidade, criminalidade etc.) e, finalmente, o que Goffman chama de estigmas tribais (raça, nacionalidade, religião etc). $\mathrm{O}$ estigma faz com o que o indivíduo seja privado de ser percebido em sua plenitude (Goffman, 1988). Dessa forma, o indivíduo estigmatizado está “inabilitado para aceitação social plena” (Goffman, 1988: 7).

É corriqueira a noção no senso comum de que o atual desprestígio do corpo gordo é um fenômeno recente. Persiste no senso comum a ideia de que, num passado idealizado, ser gordo era apenas sinal de saúde e que a corpulência era um atributo positivo para as mulheres. No entanto, autores como Vigarello (2012), ao analisar a trajetória do corpo gordo na história do ocidente, tem uma leitura diferente. De maneira bastante complexa 
e diversificada, as representações do corpo gordo oscilavam entre o excesso da gula e a abundância do abastado (Vigarello, 2012). Em outras palavras, durante o curso da história, o corpo gordo foi tanto sinal de saúde e riqueza, quanto símbolo de descontrole e fraqueza moral, pois "o prestígio do gordo está ligado, antes de mais nada, ao meio" (Vigarello, 2012).

Segundo Eknoyan (2006), os períodos de escassez de alimentos na história da humanidade contribuíram para uma conotação positiva em relação ao corpo gordo, sendo este percebido como signo de saúde e abundância de recursos. Porém, essa mesma percepção social competia com as visões médicas e religiosas do corpo gordo. Por um lado, o pecado da gula em contraste com um ideal asceta. De outro, a crescente associação da gordura corporal a males da saúde.

No Brasil, apesar de diferenças de representações em relação a outros países, o estigma da obesidade segue um caminho parecido. Até a década de 40 do século XX, ainda era comum a associação entre saúde e corpulência (Sant'Anna, 2016). A insegurança alimentar que atingia uma quantidade muito grande de brasileiros, em contrapartida, fazia com que a magreza fosse temida e vista como sinal de doença (Sant'Anna, 2016). São dessa época medicamentos e produtos farmacêuticos que prometiam aumentar a fome e fazer com o que os indivíduos escapassem da magreza. Porém, ao longo dos anos, a concepção médica do corpo gordo começou a se incorporar às representações dos indivíduos.

Para explicar essa passagem, Sant'Anna (2016) usa da metáfora do corpo-armazém e do corpo-máquina. O corpo-armazém é aquele que precisa estocar comida para épocas de penúria. Nesse sentido, a gordura corporal, um depósito acumulado de comida, era algo desejado. Porém, no contexto das sociedades industriais, surgiu uma ideia de corpo máquina, que pudesse trabalhar sempre de maneira otimizada. Dessa forma, a gordura corporal não era entendida como uma reserva boa, mas sim como uma falha do corpo em transformar um combustível (comida) em energia produtiva (Sant'Anna, 2016). Os discursos contra à gordura corporal ganham espaço e o medo de engordar se torna cada vez mais comum entre os indivíduos. Há ainda, segundo Sant'Anna (2016), uma outra mudança de paradigma: a obesidade passa a ser considerada, nos anos 80, uma "doença de pobre". Em muitos países desenvolvidos a obesidade superou a fome como problema de saúde público (Rosengren et al, 2008). Muitas pesquisas indicam que nesses países a obesidade prevalece entre famílias de baixa renda (Rosengren et al, 2008). A gula deixa 
de ser pecado para ser uma má conduta do indivíduo de baixa renda diante da sua própria alimentação.

Como aludido no subcapítulo anterior, a obesidade carrega hoje não só o status de doença, mas também é classificado como epidemia. Alguns estudos apontam, por exemplo, que pessoas obesas ganham menos que pessoas magras. Uma pesquisa feita com cerca de 14 mil empregadores brasileiros, mostrou que $68 \%$ dos empregadores preferem contratar pessoas que não estejam acima do peso. $15 \%$ desses afirmaram que não contratariam obesos para os cargos de diretoria. Um estudo feito na década de 1960 na Suécia mostrou que a ascensão social entre mulheres era mais comum entre aquelas com peso considerado normal (Rosengren et al, 2008).

O estigma da obesidade parece ter um impacto social ainda maior entre as mulheres. Autoras da escola feminista discutem essa questão desde a década de 70. A tese era que a gordura patologizada era especificamente a das mulheres (Bell e McNaughton, 2007: 108-109). Segundo Sobal (2002: 308), as mulheres são mais julgadas e mais preocupadas com sua aparência corporal, sendo o peso corporal o maior fator para julgar a atração desses corpos.

Nas entrevistas realizadas, o tema da violência na relação entre instituição biomédica e pessoa gorda foi recorrente:

“(...) os funcionários não são preparados pra receber a população gorda, porque muitas vezes entra numa cadeira ou numa maca, os maqueiros olham e dizem 'Ave maria, lá vem problema. Eu não vou aguentar levar essa pessoa'. Ou quando você entra num consultório médico e o médico já faz... 'quando eu te vi eu já sabia que já vinha problema.'. Eu já ouvi isso de médico.” (Cecília)

A violência institucional contribui consideravelmente para a conformação do estigma que acompanha as pessoas consideradas gordas. A percepção da pessoa gorda como vítima e responsável pela própria doença é bastante corrente. Segundo Laplantine (2004), existem duas possibilidades de interpretação do adoecimento: a doença-maldição e a doença-punição. A primeira, que é explicação mais comum entre as sociedades mais tradicionais, entende a doença pela ótica do acaso, da fatalidade. Nesse modelo "a doença é atribuída à onipotência da 'natureza' considerada 'má'”' (Laplantine, 2004: 228). Em 
contrapartida a essa representação, temos a doença-punição, que é quando a doença é necessariamente uma punição pelo nosso comportamento, ou seja, necessariamente um castigo pelo "pecado" cometido. Laplantine trabalha com a ideia de modelos explicativos da doença e, segundo o autor, do mesmo modo que a medicina, os doentes também elaboram seus modelos explicativos de doença. Adam e Herzlich (2001) também discutem a questão sob essa ótica. Para os autores, as pessoas "elaboram uma teoria causal constituindo uma forma de modelo explicativo da doença" (p.77). Ao mesmo tempo, destacam, "frente à sociedade, o indivíduo é basicamente saudável e a saúde é basicamente uma responsabilidade pessoal" (p.77)

O estigma da obesidade no campo biomédico pode se traduzir de três formas principais: a patologização do corpo gordo, a culpabilização por essa condição física e penalização por estar nessa condição. Antes de qualquer aferição técnica, a pessoa gorda é considerada a priori como doente. A responsabilidade por essa doença é inteiramente dela e ela deve ser, de alguma forma, penalizada por carregar essa doença. Os impactos de dessa estigmatização são inúmeros. Na fala anterior de Simone se percebe-se como a ação abusiva por parte de um ator da instituição biomédica pode afetar diretamente a saúde física e psicológica de uma paciente.

Uma das consequências da violência institucional são os danos à saúde mental dos indivíduos, como é possível verificar na fala de Simone:

“(...)ela é a mais gorda, bem mais gorda do que eu. (...) quando descobriu que tava grávida, no primeiro dia que foi pro médico, o médico disse que ela tava tentando suicídio. Ele falou isso, que ela tava tentando suicídio. O único problema dela era ser gorda. Teve o menino dela normal, não teve problema nenhum. Mas por causa de um comentário de uma médica, Nina passou os noves meses da gravidez dela péssima, passando mal, passando muito mal, angustiada, nada parava no estômago por causa de um comentário."

A autoridade médica não é só capaz de impor obediência do paciente, mas com o também tem o poder de, só com palavras, afetar o bem-estar do mesmo. Relatos como o de Simone foram recorrentes não só nas entrevistas, mas como no material pesquisado pela internet (vídeos em plataformas de streaming $^{17}$, textos em redes sociais, etc). $\mathrm{O}$ tom ameaçador que a autoridade médica impõe a esse paciente que ele considera doente é

\footnotetext{
${ }^{17}$ Tecnologia de exibição multimídia através da transferência de dados pela internet.
} 
capaz, segundo os relatos, de desencadear diversos processos dolorosos à essas pessoas. Além de afetar a saúde mental dos indivíduos, a repetição sistemática dessa experiência de abuso tem outro efeito: o afastamento de pessoas gordas das instituições que cuidam da saúde das mesmas, como é possível notar nas seguintes falas:

“Como tem o relato de uma menina, que ela foi fazer cirurgia da vesícula. Tudo pronto, o cirurgião disse: eu não vou te tratar, eu não vou te operar. Você é gorda, você vai morrer na minha mesa de cirurgia, eu vou me prejudicar. E ela foi embora com a vesícula dela doendo, com o problema dela de vesícula e não quis mais voltar mais em médico nenhum" (Cecília)

“é justamente as pessoas não param pra te analisar, não param... não tentam ver aquilo que realmente você tem, sua necessidade médica e eles te julgam simplesmente pelo fato de você ser gordo, né. E isso fez com que eu me afastasse muito de ter que ir a um consultório médico. E eu seu que isso acontece com muitas outras mulheres, com muitas outras pessoas gordas no geral." (Cecília)

A médica entrou, olhou pra minha cara, nem me perguntou nada, não me pediu um exame e virou pra mim e mandou: "Por que você não faz uma bariátrica?" Falou assim, de graça. Só que eu tinha ido até lá pra ver meu estômago. Aquilo me impactou muito. Ela não me pediu um exame, não olhou nem na minha cara! (Lúcia)

Segundo Puhl e Heuer (2010), é a visão estigmatizada que coloca a pessoa gorda como preguiçosa, desonestas, chatas, indisciplinadas que faz com que esse grupo passe a evitar o atendimento médico:

Um grande número de pesquisas descobriu que o modo como o atendimento à saúde é estruturado é uma fonte significativa de estigmatização do peso corporal, o que afasta pacientes obesos de procurar cuidado médico apropriado. Tanto relato de pacientes como pesquisas experimentais demonstram estereótipos e atitudes negativas contra pacientes obesos num largo espectro instituições ligadas ao cuidado da saúde e professionais de educação física, incluindo percepções que pacientes obesos são preguiçosos, indisciplinados, desonestos, ignorantes, chatos e que não aderem aos tratamentos. 
Existem pesquisas que indicam que provedores de saúde passam menos tempo no atendimento com pacientes obesos comparados aos seus pares mais magros. ${ }^{18}$

A violência institucional contra as pessoas gordas se manifesta não apenas através do abuso verbal, mas também pela própria estrutura e disponibilidade de equipamentos adequados das instituições, que, segundo as entrevistadas, não estão aptas para acolher, tratar ou diagnosticar pessoas gordas.

"Eu conheci uma mulher que ela teve câncer no colo de útero, mas ela nunca soube porque ela não cabia na cadeirinha de fazer o preventivo. Porque a cadeira preventiva é $100 \mathrm{~kg}$, e já tinha 150. Aí só veio descobrir quando ela tinha um câncer quando foi fazer a cirurgia bariátrica. Então, quantas pessoas estão morrendo exatamente por isso?" (Carla)

"Um amigo foi fazer uma cirurgia de apêndice no hospital, colocaram ele na maca e ele caiu da maca. A maca quebrou com ele. E ele teve quer levado à sala de cirurgia as pressas, porque na queda, como ele bateu a barriga, poderia ter... o apêndice poderia ter estourado e se estourasse dentro dele, seria horrivel pra ele porque poderia ter gerado uma infecção. E isso é uma coisa que, é algo que é básico, uma maca, não é?" (Cecília)

A dificuldade de ter uma cadeira pra você sentar, a dificuldade de ter um tensiômetro pra tirar sua pressão, equipamentos básicos, uma maca que você caiba, que você não tenha medo de sentar e de cair. Então esse tipo de coisa faz com que a gente não vá, né. (Cecília)

Dessa forma o que se tem é uma cadeia de violências institucionais múltiplas contra a pessoa gorda: a biomedicina acusa o corpo gordo de ser doente, afirma que essa doença é auto infligida, e, na sua prática ela, se não nega, precariza o cuidado a esse corpo. Segundo Russo (2006), a doença, no entendimento da biomedicina, é indissociavelmente física e moral. Cada vez mais o processo de adoecimento é associado a uma falta de moral,

\footnotetext{
${ }^{18}$ Original: An accumulation of research has found that health care settings are a significant source of weight stigma, which undermines obese patients' opportunity to receive effective medical care. Both selfreport and experimental research demonstrate negative stereotypes and attitudes toward obese patients by a range of health care providers and fitness professionals, including views that obese patients are lazy, lacking in self-discipline, dishonest, unintelligent, annoying, and noncompliant with treatment.There is also research indicating that providers spend less time in appointments and provide less health education with obese patients compared with thinner patients.
} 
ou, em outras palavras, a uma vida desregrada, ressalta a autora. A exemplo disso, a obesidade é comumente atribuída a uma falha no comportamento dos sujeitos. Nesse sentido, o profissional de saúde tem tanto a autoridade de prescrever a cura da doença quanto de prescrever para o indivíduo um modo de viver correto (Russo; Souza e Pitanguy, 2006), como pode ser verificado na fala de Cecília:

“Eu tenho o problema muito grande com o atendimento médico. É algo que eu preciso tratar em mim. Por conta de... você vai à um médico pra poder tratar umas coisas simples eles viram pra você com uma guia de emagrecimento, uma guia de uma cirurgia. E isso me incomoda. Até eu aprender a lidar com os médicos, é... eu sofri muito, né. Porque realmente eles te passam, te dizem 'você vai morrer, você tá gorda, você vai morrer. Você precisa emagrecer senão você vai morrer.",

No campo da biomedicina muitos autores defendem a estigmatização da obesidade como uma abordagem positiva. A tese é que essa estigmatização serviria como um incentivo para os indivíduos adotarem hábitos mais saudáveis. Outros autores, porém, argumentam o contrário. Para Puhl e Heuer (2010), não existe indícios de que isso tenha comprovação. Segundo os autores, o estigma da obesidade, ao contrário, pode servir de gatilho para que indivíduos adotem hábitos considerados não saudáveis. Ainda segundo os autores, o estresse causado pela vivência do estigma estimula a produção de hormônios que são associados ao ganho de peso. 


\section{Capítulo IV - CORPO E COMIDA}

\subsection{Dieta, dietética e nutricionismo}

Correntemente, é comum a associação entre dieta de restrição alimentar e perda de peso. Porém, na sua raiz, o termo dieta é bem mais complexo. Diaita, palavra da qual derivou a dieta, era usada pra descrever todo um modo de vida guiado pela saúde (Foxcroft, 2013). Sendo um ramo fundamental da medicina antiga, a dietética é formada por uma série de convicções e conhecimentos sobre alimentação aplicados à saúde (Flandrin; Montanari; Mazzini. 2015). Existia, já na antiguidade, um grande interesse na relação de causalidade entre alimentação e saúde/doença. Para Hipócrates, a base da saúde humana consistia na alimentação, no trabalho (exercício físico) e uma grande ingestão de alimentos que deveria ser acompanhada de quantidade equivalente de trabalho, para que, dessa fora, o alimento fosse corretamente assimilado. Na perspectiva dessa medicina, saúde e doença se manifestavam pelo equilíbrio e desequilíbrio dos elementos que compõem o corpo humano.

Dessa forma, os alimentos tinham a função de conservar ou dar saúde (equilíbrio) para os indivíduos (Flandrin et al, 2015). Essa medicina baseava-se no princípio de que todos os seres vivos possuem "uma 'natureza' particular em razão da combinação de quatro fatores, agrupados dois a dois: quente/frio, seco/úmido" (Montanari, 2004. p.84). Portanto, ter perfeita saúde significava um equilíbrio entre esses quatro elementos. Hipócrates ainda reconhecia que era difícil prescrever um regime de alimentação e trabalho que servisse para todas as pessoas. Para as pessoas gordas, Hipócrates tinha recomendações que hoje podem parecer bastante controversas, como a indução do vômito; refeições durante o período de trabalho; uso de óleos corporais; banhos mornos, etc. (Foxcroft, 2013).

Ainda nesse período, predominava a noção de que a comida tinha como função apenas o sustento e que comer demais era moralmente recriminado. A glutonaria era mal vista e comumente associada com promiscuidade, podendo até destruir reputações (Foxcroft, 2013). Segundo Plutarco, historiador grego "não devemos, portanto, satisfazer nossos apetites com iguarias ou com dia luxuosa, para não nos tornarmos corpulentos" (Foxcroft, 2013: 32). Dessa forma, não seria equivocado afirmar que desde o período clássico que corpo gordo e gula são associados. 
Muitos princípios da ciência nutricional contemporânea podem ser encontrados nesse período: a variedade, a moderação, a personalização da dieta e a higiene. Hoje, as teorias e as práticas nutricionais, que buscam a prevenção e o combate à doença, passam a prescrever as teorias e práticas dos sujeitos: o que comer, quando comer, quanto comer, como comer (Carvalho; Luz; Prado, 2011). Os aspectos simbólicos e hedonistas da alimentação são preteridos em função dos aspectos objetivos ditados pela ciência nutricional. Cria-se assim "um ideal de alimentação único que independe do conjunto de representações, conhecimentos e práticas aprendidas e compartilhadas pelos indivíduos de um grupo social." (Kraemer; Prado; Ferreira; Carvalho, 2014. p. 1337).

A alimentação nesse contexto é concebida como simples ingestão de nutrientes e calorias, que estão a serviço de um funcionamento normal e útil do corpo. Pra Kraemer et al (2014) o discurso da alimentação saudável é uma estratégia de biopoder, desenvolvida por Michel Foucault. Nessa perspectiva, no olhar científico da medicina, "há um afastamento da escuta sensível, da percepção do sujeito (...) e do seu processo de adoecimento e uma valorização do modelo nosológico de identificação, localização e classificação da doença.” (Kraemer et al, 2014. p.1343).

Dessa forma, as políticas públicas em alimentação se configuram de maneira a reorientar o comportamento alimentar dos indivíduos, recomendando a eles a exclusão ou a moderação de alguns alimentos e o estímulo a outros, considerados mais saudáveis e que nos levam a um lugar de normalidade do corpo (Kraemer et al, 2014). Concordando com esse ponto de vista, Sousa (2012) afirma que "a vida da população é regrada por enunciados que invadem todos os espaços da convivência social" (p.49), enunciados que ditam o que é e o que não é permitido na vida dos indivíduos, sempre com a promessa da melhora na qualidade de vida e no aumento da longevidade.

Segundo Scrinis (2008), a indústria da nutrição (nutricionistas, nutrólogos, autoridades da saúde pública) tem, ao longo dos anos, encorajado as pessoas a ver comida enquanto um depósito de nutrientes e compostos bioquímicos. Scrinis batizou essa abordagem em relação a comida de paradigma ou ideologia do nutricionismo. Porém, essa prática da nutrição, apesar de hegemônica, encontra discordâncias. Publicado em 2006, O guia alimentar para a população brasileira, é o primeiro documento produzido pelo governo federal com diretrizes sobre alimentação para a população brasileira. Produzido pelo Ministério da Saúde, a fundamentação teórica desse guia está de acordo com os propósitos do Plano Nacional de Alimentação e Nutrição (PNAN) e com os 
objetivos preconizados pela Organização Mundial de Saúde. Esse guia traz alguns pontos importantes para compreender a política oficial do Brasil em relação à alimentação:

Comer comida ou comer nutrientes: O guia afirma, logo em seu início, que a alimentação se dá através do consumo de alimentos e não de nutrientes, de forma que uma alimentação saudável deve ser pautada em práticas alimentares que tenham significado social e cultural. Embora sejam importantes os nutrientes, ainda afirma o guia, o alimento como "fonte de prazer e identidade cultural e familiar também é uma abordagem necessária para promoção da saúde” (p.15), concordando com Garcia (1997) que afirma: "Se do ponto de vista biológico temos certas necessidades a serem preservadas, do ponto de vista sociocultural também temos necessidades a serem preservadas através da alimentação" (p.53).

Comer enquanto decisão individual: Fischler (1979) abordou como a gramática da alimentação foi desestruturada em função de uma individualização do ato de comer. Ao falar de alimentação saudável, o guia faz uma ressalva: "Aquilo que se come e bebe não é somente uma questão de escolha individual." (p.22), corroborando com a compreensão de que fatores sociais, como renda, educação formal, família, acesso aos alimentos são formadores de práticas alimentares.

Referencial restritivo e referencial positivo: Um dos princípios que norteiam o guia é o de referencial positivo. Os alimentos considerados saudáveis devem ser estimulados, ter suas virtudes ressaltadas. Porém, os outros, que não são considerados saudáveis e cujo uso deve ser moderado, não devem ser proibidos. De acordo com o guia, deve-se fomentar os hábitos alimentares tradicionais saudáveis dos brasileiros e ao mesmo tempo informar sobre os malefícios de determinados grupos de alimentos. Dessa forma, a autonomia das pessoas e a cultura alimentar - em oposição à ideia de globalização da dieta - são preservadas.

\section{Questões sobre alimentação contemporânea}

Tomando como base o conceito de anomia em Durkheim, no seu texto clássico sobre o suicídio, Fischler faz um jogo de palavras entre gastronomia e a anomia. O conceito de gastro-anomia serve pra chamar atenção para a dificuldade que os indivíduos têm tido em lidar com a grande complexidade do ato de comer e suas representações nas sociedades contemporâneas. A hipótese é a de que as sociedades têm códigos muito complexos em 
relação ao ato de comer: o que comer e o que não comer, quando comer, intervalo entre refeições, rituais, com quem comer etc. Todos esses códigos (pré)estabelecidos vão entrar em atrito com o surgimento de novas questões; como a maior oferta de alimentos; discursos científicos sobre a nutrição humana; associação entre alimentação e saúde, a lipofobia ${ }^{19}$ etc. Nesse contexto, no momento em que esses códigos tradicionais começam a ruir, surge a sensação de incompetência para comer. Sobre essa ideia, Fischler afirma:

Eu quis dizer mais ou menos a mesma coisa que já estava sendo dita de outras maneiras: que quando falamos de comida não estamos falando só de nutrição, comida não é só nutrientes, calorias, proteínas, vitaminas, etc. Existem regras que estão implícitas no ato de comer, que os comedores seguem sem ter consciência que estão seguindo, como as coisas que se pode comer ou não, as horas em que se deve comer, o número de refeições diárias, com quem se deve comer, qual a etiqueta que se deve seguir, etc. Regras que todos seguem sem saber que estão seguindo. Existe, portanto, uma gramática e uma sintaxe quando se come. (...) O que abordo nesse texto de 1979 é a desestruturação dessa sintaxe em função da individualização do ato de comer. Hoje, não se tem mais ao certo quais as regras que devem ser seguidas. Existem muitas informações e conselhos que são conflituosos. Não se sabe qual deles se deve seguir. Como resultado, existe uma insegurança e desconfiança cada vez maior do comedor. (Goldenberg; Fischler 2011)

Em Le (H)omnivere, Fischler traz dois outros conceitos importantes: cacofonia alimentar e polifonia dietética. Para o autor, com a industrialização do setor alimentício, normas e preferências alimentícias localizadas se convertem em "apostas econômicas planetárias". Nesse terreno, cientistas e especialistas vinculados à indústria da alimentação disputam o espaço do saber relacionado à comida, cada um em defesa de sua tese. Nesse contexto, instala-se uma polifonia dietética: o Estado, médicos de diversas especialidades, a indústria alimentícia, a publicidade e a mídia servem de guia para os comedores. Essa polifonia se funde a uma cacofonia alimentar: discursos dietéticos se confundem com discursos culinários, livros de regime com livros receitas, manuais de nutrição com guias gastronômicas (Fischler, 1995). Nesse cruzamento de informações, o comedor, confuso, vai perdendo gradualmente a sensação de que é competente para gerir sua alimentação.

19 Termo cunhado por Fischler para explicar à aversão das sociedades contemporâneas à gordura - tanto na comida quanto no corpo. 
Mesmo antes do processo de industrialização da comida, era necessária alguma competência para comer (Fischler, 1995). Porém, essa competência estava ligada às diferentes condições sociais para a aquisição do alimento, da sua técnica de preparo, como compartilha-lo com o outro etc (Fischler, 1995). Os outros aspectos do comer eram de responsabilidade coletiva, havendo um processo de mudança nas sociedades individualistas contemporâneas.

$\mathrm{Na}$ atualidade, surge a ideia de comedores competentes. É preciso que cada indivíduo sintetize todas as informações disponíveis para que se tome uma decisão racional, correta e competente sobre o que e quando comer (Fischler, 1995). Nesse cenário, diferentes doenças são associadas, pela biomedicina, a uma falta moral, dada pelo não cumprimento pelos indivíduos das diretrizes prescritivas sobre sua saúde. Doenças estão associadas a um modo de vida desregrado. Nesse contexto, alimentar-se de acordo as prescrições da biomedicina se torna uma responsabilidade moral do indivíduo (Russo, 2006). A alimentação vai além da simples ingestão de ingredientes, ela se torna também uma visão de mundo e expressão de valores (Russo; Souza e Pitanguy, 2006).

$\mathrm{Na}$ presente pesquisa, as entrevistadas foram perguntadas sobre a relação delas com a comida. Observou-se uma complexa relação entre o discurso hegemônico, a apreensão que é feita desse discurso pelo senso comum e uma busca por uma certa autonomia no comer, revelando-nos uma dificuldade em escolher um entre as várias "filosofias" alimentares possíveis. Para Carla, uma das entrevistadas, existe uma dificuldade em se adequar à alimentação dita saudável. Representações do saudável como comer bastante folha, se alimentar de três em três horas aparecem na fala dela se opondo aos hábitos alimentares que ela tem:

"Eu não me alimento a cada três horas, não me alimento coisas saudáveis, como a população fala. (...) Eu não como folha o tempo todo. Eu gosto de comer fritura, eu gosto de comer carne, eu gosto de comer pizza, eu gosto de comer tudo que é bom, que é imoral, ilegal."

Segundo Fischler (1995), como anteriormente mencionado, vivemos em uma "cacofonia dietética", onde diversos discursos sobre alimentação se mesclam: "os discursos dietéticos se mesclam, se enfrentam ou se confundem com os discursos culinários e gastronômicos, os livros de regime com os livros de receitas, os manuais de 
nutrição com os guias gastronômicos. ${ }^{20 "}$ (Fischler, 1995: 195). Nesse contexto, múltiplos discursos podem orientar a alimentação dos indivíduos: recomendação de médicos e nutricionistas, o hedonismo dos chefs da televisão, apropriação da ciência pelas revistas femininas, etc. Dessa forma, não há um único caminho a seguir, sendo cada indivíduo responsável por formular suas próprias teorias e práticas em relação ao comer. Esse horizonte de alimentação saudável, na fala de Carla, entra em conflito com aquilo que ela gosta: tudo que é bom, imoral e ilegal. É a "cacofonia dietética", descrita por Fischler. Se por um lado o discurso biomédico tenta moralizar alimentação, prescrevendo o que é certo e errado, por outro, o discurso hedonista da gastronomia seduz com a promessa do prazer. Já a entrevistada Simone, mesmo sem necessariamente discordar do discurso da alimentação saudável, diz preferir optar pela sua autonomia:

“Eu como fruta porque eu gosto, não é porque é mais saudável, não. Eu... eu... eu pra mim não admito ficar comendo coisas porque é saudável, sabe? (...) Isso pra mim é inadmissível, eu sentar com alguém e fazer uma dieta pra mim, eu acho um absurdo. Eu... aceito, né? Porque cada um tem que viver a sua vida do jeito que quiser, mas pra mim, Simone, eu sei o que eu posso e o que eu não posso comer (...)"

É notório na fala de Simone seu conflito com a prática de dieta e do profissional de nutrição. O comer para ela não é pautado pela busca da saúde perfeito ou pelo corpo magro. Suas escolhas estão pautados por outro referencial: o do prazer. Em outro momento, Simone explica sua escolha:

"Eu sou uma mulher inteligente, eu sei o que eu devo ou não comer, eu sei que uma coxinha é fritura e que pode causar, vai me engordar mais ou não do que eu sentar pra comer uma maçã. (...) eu sou livre, eu quero ser livre, eu quero comer o que eu quiser, mesmo que seja 100 coxinhas pra entupir minhas artérias e eu morrer ali, mas eu quero ser livre pra eu poder fazer as minhas escolhas."

Carla mostra-se em conflito com os diversos discursos sobre alimentação, desvelando uma questão importante: é possível seguir todas as recomendações da ciência nutricional? Como apontado por Fischler (1995), a responsabilidade do "comer bem"

\footnotetext{
${ }^{20}$ Original: "los discursos dietéticos se mezclan, se enfrentan o se confunden con los discursos culinarios y gastronómicos, los libros de regímenes con los libros de recetas, los manuales de nutrición con las guías gastronómicas"
} 
recai sobre os indivíduos, que, frequentemente, se sentem frustrados por não conseguir se adequar aos preceitos da nutrição.

"E tem pessoas que levam uma vida muito mais saudável que a minha que tem horário pra tudo, que dorme, que se alimenta corretamente, corretamente na visão nutricional e que não tem metade da saúde que eu tenho ou metade da saúde que as meninas têm, né? Porque a mídia nos força a ter uma visão de alimentação que talvez não seja certa, porque pra cada um vai ter uma forma de se alimentar mais adequada, né? Mas eu, assim, eu sei que grande parte é responsabilidade minha, eu gosto minha de beber refrigerante, bebo cerveja, então... pra mim todo dia é dia de festa, então minha alimentação é errada," (Carla)

\subsection{Transtornos alimentares}

Nesse emaranhado de dúvidas, incertezas, múltiplas pressões sobre saúde, corpo e todas as contradições advindas dos modos mais adequados de comer, os comedores vêm gradualmente se fragilizando. Os transtornos alimentares, o uso de inibidores de apetite, transtornos ansiosos e compulsivos são fruto dessa realidade. A esse respeito, Fischler afirma:

\footnotetext{
Nas minhas pesquisas aparece muito fortemente um fato: as pessoas sentem-se desconfiadas, confusas e incompetentes porque não sabem o que estão comendo. As pessoas estão cada vez mais inseguras com relação ao que comem. São consumidores mais fragilizados, ameaçados cotidianamente com informações sobre pesticidas, aditivos, corantes, conservantes, aromatizantes, produtos que podem provocar doenças graves ou até mesmo matar. (...) Com a desestruturação dos sistemas normativos e de controle social que regulavam tradicionalmente as práticas alimentares, pode-se dizer que está havendo uma "psicopatologia da alimentação cotidiana". (Goldenberg; Fischler 2011).
}

Alguns estudos apontam também uma associação entre problemas com autoestima e depressão com a obesidade (Rosengren et al, 2008), bem como o sofrimento familiar, como aponta Oliveira (2011). Transtornos alimentares como anorexia nervosa, bulimia nervosa e transtorno da compulsão alimentar periódica também vem sido associados com o estigma da obesidade (Day et al, 2011). Nesse contexto, alguns autores afirmam que existe uma epidemia complementar à da obesidade: a de dieta e de transtornos alimentares (Rosengren et al, 2008). 
Para a entrevistada Lígia, a prática de dietas se iniciou por desejo da família:

Então, como eu fui criada a vida toda por dietas restritivas, o tempo inteiro com o "não pode, não pode, não pode”, quanto mais não podia, mais eu queria e mais compulsão crescia. Eu falo que compulsão alimentar é que nem qualquer outro vício: você não se considera mais alcoólatra. (Lígia)

É frequente nas falas o relato da preocupação familiar em relação ao corpo das entrevistadas. Dietas restritivas, visitas à nutricionistas e médicos, práticas atividades físicas eram iniciativas comuns de pais e familiares diante do corpo de uma criança que está engordando. Para Cecília, o desejo de não ter um corpo gordo a levou à prática de jejuns logo aos doze anos:

“eu lembro, acho que mais ou menos onze, doze anos de idade que ela passou a fazer isso, quando eu cheguei aos quinze anos de idade, tinha semana que eu ficava a semana toda sem comer, só bebendo água, eu não emagrecia, muito pelo contrário, eu ficava engordava mais ainda, porque eu ficava ansiosa pra ver o resultado e eu não conseguia. Então eu ficava a semana toda sem comer nada, só bebendo água ou comendo uma fruta ou uma coisa assim, muito dificil. E... depois que... acho que até os vinte e cinco anos eu fui assim, mesmo." (Cecília)

Tereza também relata sua relação com dietas restritivas:

"mas eu tive uma relação muito bizarra com comida durante muitos anos nessa base da sempre restrição, sempre restrição. Hoje em dias às vezes ainda voltam algumas coisas, mesmo não sendo com relação a eu emagrecer, tipo: eu tava passando meio mal do estômago porque eu tenho esofagite, ai eu pensei: "Ai, acho que to bebendo muito e to comendo muita fritura. Então, tá bom, a partir de amanhâ eu não vou mais comer nenhumaritura". Ou seja, a gente sempre vai pro lado da restrição. Eu pensei isso hoje e, logo em seguida, falei: “Não, não". Porque eu sei que qualquer tipo de restrição, ainda mais pra mim, tende a ir pro lugar da compulsão." (Tereza)

Segundo Gormally e tal (1982), a prática de dietas restritivas está intimamente ligada aos episódios de compulsão alimentar. Nesse sentido, outras abordagens são 
buscadas pela nutrição, como a chamada HAES (Health at Every Size ${ }^{21}$ ). Essa abordagem preconiza que o foco do profissional de nutrição deve ser nos hábitos do indivíduo e não no seu corpo.

${ }^{21}$ Tradução livre: saúde em qualquer tamanho. 


\section{A MILITÂNCIA ENQUANTO HORIZONTE DE MUDANÇA}

Em uma postagem no seu blog pessoal ${ }^{22}$, a militante gorda Cat Pausé indaga: quem é dono da epistemologia sobre o corpo gordo? Quem produz, ou melhor, quem pode produzir o conhecimento sobre esses corpos? A tese de Cat é a de que as pessoas gordas sabem sobre si, sobre sua vida, sobre seus comportamentos e sobre como elas experimentam a vida. E mais: elas são produtoras de conhecimento sobre o corpo gordo. Segundo a ativista e pesquisadora da militância gorda Cooper (2016), é importante discutir quem pesquisa e quem produz conhecimento sobre o corpo gordo. Ainda segundo a autora, é necessário evidenciar as experiências dessas pessoas, como no emblemático slogan "Nada sobre nós sem nós"23.

A militância gorda é frequentemente acusada por atores da instituição biomédica de incentivar as pessoas a adotarem hábitos danosos à saúde. Ancorados na ideia de que não existe possibilidade de ser gordo e saudável, a militância gorda é vista como uma forma de ameaça à saúde pública. Porém, os relatos mostram outro caminho.

Não são raros os relatos de pessoas gordas que vivem reclusas da convivência social, privadas de trabalho, atividades de lazer, educação, etc. As dificuldades de locomoção, de encontrar roupas adequadas, além do assédio contra elas, fazem com que muitas pessoas não consigam sair da própria casa, como é possível verificar na fala de Cecília, uma das entrevistadas:

“Eu, durante muito tempo fui muito... eu sou uma pessoa tímida. Na verdade, eu acho que não é uma timidez minha, essência. Mas é uma timidez que acabou acontecendo por conta de ouvir durante muito que as pessoas não iam querer me ouvir, que as pessoas não iam querer conversar comigo por eu ser uma pessoa gorda. Eu acho que as piores fases pra uma pessoa gorda são a adolescência e a infância, quando a sua própria família ${ }^{24}$ te impõe essas coisas. E eu passei por isso durante muito tempo e eu era uma adolescente que eu não tive amizades. Eu fui uma criança que não tive amigos. Então por conta disse eu não aprendi a lidar com outras pessoas. Eu vivia dentro do meu quarto, é meu lugar, é o lugar que eu gosto de estar é o meu quarto. Porque desde criança eu tive isso. Então eu acabei me fechando mesmo pro mundo de uma forma geral. Malmente era o colégio e casa. E biblioteca. Eu ficava muito na biblioteca do Rio Vermelho. E... e era um mundo

\footnotetext{
${ }^{22} \mathrm{https}$ ://friendofmarilyn.com/2012/04/05/the-epistemology-of-fatness/

${ }^{23}$ Original: Nothing about us without us.;

${ }^{24}$ Ver Oliveira (2011), op.cit.
} 
isolado mesmo, eu era uma pessoa que me isolava das pessoas pra não ter esse contato de não precisar do olhar do outro, do olhar que as pessoas me recriminassem pelo fato de eu ser gorda. É... eu... pelo menos eu acabei desenvolvendo uma insegurança muito grande de falar com as outras pessoas, de me relacionar com outras pessoas, de... até mesmo pra trabalhar, pra tudo, mesmo. Preciso sempre de alguém comigo, pra que eu tenha um pouco de segurança pra poder falar com outras pessoas, e... isso dificulta muito, e... até os 27, 25 anos de idade eu fui assim."

Porém, o contato com outras mulheres que tinham experiências de vida parecidas com a sua, fez com que Cecília se abrisse pra novas possibilidades. Ver que outras mulheres, que tinham um corpo semelhante ao seu, tinham trabalho, relacionamentos afetivos, amigos, se exercitavam etc., fez com que Cecília vislumbrasse essa possibilidade para si mesma:

À partir dos vinte cinco anos que eu conheci outras pessoas. Eu conheci na verdade essa parte da militância, não era militância, no Orkut não era essa parte, não existia militância realmente. Era grupos de relacionamentos mesmo, de pessoas gordas, né. A gente começa... hoje a gente fala muito do fetiche, mas... essa parte de fetiche naquela época foi algo que salvou muita gente. Porque não era normal mulheres gordas serem desejadas. E o Orkut trouxe isso muito forte, né... E... e aí foi quando eu vim a conhecer a internet, foi com 25 anos, que eu fiz o orkut, que eu fiz o perfil no Orkut e comecei as comunidades de mulheres gordas, e... eu conheci uma página chamada cotidiano gordo e peso do preconceito, o peso do preconceito, que elas falavam de uma forma política $E$ aí, é... tinha o site também, elas tinham um site. E eu comecei a ler sobre coisas, era relatos de mulheres, mulheres gordas, negras, que tinham a visão completamente diferente daquilo que eu via, daquilo tava vivenciando, né. Vim conhecer já tava com um ano mais ou menos de Orkut, tinha vinte e seis anos. E aí as coisas a mudar um pouco na minha forma de pensar. Que elas falavam do cotidiano delas e eu vi que não estava sozinha, né. Porque geralmente as imagens que nós víamos na internet eram de mulheres gordas, porém mulheres brancas, então às vezes eu não me enxergava porque era uma outra realidade, né. No caso, você vê as histórias de uma mulher gorda, negra, da periferia é diferente de uma mulher gorda, branca, mesmo que seja periférica, mas, e se for de outra classe social ainda é mais diferente ainda. Então quando eu comecei a ler o relato dessas outras mulheres eu comecei a ver que eu não estava sozinha. E isso fez com que minha vida fosse mudando. Vi que minha vida poderia, sim, ser feliz dentre todos 
meus defeitos, né, que na época que eu achava que o meu corpo gordo era um defeito, mas que eu poderia conviver com esse defeito.

Essa experiência de se ver no outro mostra-se profundamente transformadora para Cecília. A possibilidade de se ver para além do que dita o estigma, de ver que outras formas de vida são possíveis, transforma a vida de Cecília e a impulsiona a transformar a vida de outras mulheres gordas:

E aos poucos eu fui conhecendo, fui aprendendo, e pra mim... eu não sabia que a escritora dessa página, a pessoa que fazia esses relatos, era uma mulher de Salvador. Ela é uma pessoa de Salvador. E nesse momento há uns quatro, cinco anos atrás, foi quando eu conheci. Eu tava num shopping e tava tendo reunião da gente e ela chegou com uma outra pessoa que tava ajudando a gente na organização da caminhada e ela chegou e quando eu vi aquela mulher eu comecei a chorar porque ela foi a mulher que mudou a minha vida em muita coisa, os relatos dela, as vivências dela, me fizeram entender que eu não estava sozinha. E foi aí que eu comecei a também a desenvolver a vontade de fazer militância. Que eu entendi que minha vida havia mudado, tanto que mudou por conta dos relatos daquela mulher. E que os meus relatos também que eu poderia ajudar outras mulheres, que se eu fizesse, outras mulheres entenderiam elas poderiam ser felizes, que elas poderiam se aceitar como mulheres gordas."

Esse sentimento de transformação, de mudança, também é relatado por Simone, que acredita que sua vida se define em antes e depois de fazer parte da militância gorda.:

“Minha relação com a militância gorda é maravilhosa. Dura, árdua. Não a relação que eu tenho com as meninas, mas o próprio movimento mesmo. É um movimento de resistência. Eu busco na minha memória a Simone de antes e a Simone de hoje. E eu não trocaria por nada. Hoje eu tenho o mesmo peso de antigamente, de um 5 anos atrás. Mas a diferença, minha postura, diante de mim, diante do meu corpo, diante dos meus amigos, diante dos meus relacionamentos, realmente amorosos, diante da minha família, diante de todo mundo que vem questionar por eu seu gorda, porque eu que eu não emagreço, que vem com receita... a minha postura é outra. Antigamente eu me escondia, antigamente eu não me via desejável, é totalmente diferente. Eé muito bom a Simone que eu me tornei." 
Simone relata que durante muito tempo aceitou todas as representações negativas sobre o corpo gordo como verdadeira, vivendo um período muito grande de ojeriza a si mesma:

"Já houve um tempo em que eu me odiava, essa é a palavra. Conversando uma vez com minha melhor amiga, ela disse: Simone eu não percebia isso! Mas era porque eu vivia na clandestinidade. Eu odiava meu corpo mas não podia dizer porque eu me sentia inferior, eu me sentia feia, eu achava que nada ficava bom em mim, eu queria vestir preto, eu só queria vestir cores que eu me escondesse, e eu realmente escondia meu corpo porque o tempo todo as pessoas estavam me criticando."

Para Simone, a principal transformação foi a de perceber que, na verdade, o inferno eram os outros. Enquanto vivia "na clandestinidade", se escondendo, ela sofria com o estigma que recaia sobre ela. Porém, a partir da militância, ela passou se posicionar de forma crítica a esse estigma, possibilitando que ela pudesse viver sua vida de forma mais plena.:

"E o que mudou em relação ao meu corpo é que eu percebi que eu nunca me incomodei. Eu não tenho uma memória de dizer, "ah, eu me incomodei com meu corpo", na verdade o que me incomodava e o que incomoda são as outras pessoas falando do meu corpo. E hoje minha relação é ótima. Tem partes do meu corpo que eu não gosto, lógico. Mas a diferença é que eu não deixo de sair, não deixo de curtir, eu não vou me relacionar com uma outra pessoa no escuro, porque eu tenho vergonha do meu corpo. Hoje eu não vivo obsessiva, deixando de comer as coisas que eu gosto, deixando de ir para os lugares que eu gosto. Essa é a mudança: eu mudei a relação com meu corpo. Hoje eu consigo me olhar no espelho. Hoje eu entendo que o problema não estava no meu corpo.

Lúcia explica essa passagem do ódio a si para a aceitação, como uma venda que se tira dos olhos, venda essa que é a da gordofobia.:

"A minha vida hoje é muito melhor. Como é que eu vou te explicar? Parece que tiraram uma venda dos meus olhos. Eu tava vivendo no mundo de mentirinha e agora eu to 
vivendo no mundo real de muito mais amor, de muito mais liberdade, de muito mais.. não aceitação, porque eu já me aceitei. Acho que é de felicidade, sabe?"

A transformação, para Lúcia, está no fỉm da luta contra seu próprio corpo. Rejeitando as recomendações da biomedicina, onde só pode se encontrar saúde na magreza, Lúcia entende que a auto aceitação foi o principal passo para a transformação de sua vida.:

"Essa três palavras são muito pertinentes porque eu parei de brigar comigo, eu parei de brigar com o meu corpo. Eu parei de brigar. Eu comecei a ter essa liberdade, a ter esse amor, a olhar o mundo; o mundo ficou diferente depois que tudo isso aconteceu. Antes a sensação que tenho era que eu vivia sendo um robozinho. Tipo: "Faz isso, faz aquilo", eu vivia andando com aquele negócio bem da sociedade mesmo: "Cresça, faça faculdade, tenha um trabalho, trabalhe que nem uma filha da puta, não olhe pra você, tome qualquer medida pra você ser uma pessoa magra e isso requer você quase morrer por causa de anfetamina". Eu olho isso tudo e a única coisa que eu me arrependo é de ter demorado tanto tempo pra poder ter essa consciência. Eu não acho que foi tarde, porque eu acho que sempre tudo tem um tempo certo de acontecer, mas eu acho que poderia ter sido antes. Mas hoje é muito melhor do que era antigamente.

Já para Tereza, a militância fez com o que ela lidasse com as questões relativas à saúde de uma maneira mais tranquila, sem a busca incessante por emagrecimento através de dietas e exercícios físicos:

Eu acho que lido de uma maneira mais tranquila, bem mais tranquila. Eu me preocupo com a minha saúde, porque acho que todo mundo deveria se preocupar. Eu me movo, faço exercício como razoavelmente bem, mas eu também não deixo de comer coisas que eu gosto, porque são coisas ruim para minha saúde ou coisas do tipo. Não faço dieta restritiva de jeito nenhum, acho que isso não leva ninguém a lugar nenhum e tem esse perigo pra mim d'eu tirar e a compulsão e tento me mexer pela questão da saúde. Mas eu fico me observando, porque eu acho que isso tá bem canalizado dentro de mim, então a qualquer momento pode acontecer uma coisa de saúde, um problema de circulação, porque, por conta da trombose, eu faço exame de circulação todo ano, tem uma médica vascular que eu vou. É um acompanhamento mesmo que eu vou ter que fazer pro resto da vida, eu não posso tomar pílula anticoncepcional por causa disso, por exemplo, 
porque pode ativar outra crise circulatória. Então, eu tenho que ficar meio que me policiando também pra, quando eu tenho alguma coisa, a resposta internamente do corpo não ser: "Ah, to gorda, preciso emagrecer." Mas eu acho que hoje é isso. Um tempo atrás eu não queria essa coisa de logo em seguida pensar: "Ah, não, não é isso”, mas hoje quando têm essas respostas eu já lembro, porque tratar da saúde é outra coisa, o foco não é perder peso. O foco é ter hábitos saudáveis, tá tudo bem, tanto que na verdade uma das coisas, dos hábitos que eu acho que eu deixei de ter e que foi a primeira coisa que eu fiz quando eu parei de tentar emagrecer e que pra mim é muito positivo e que eu acho que todo mundo devia fazer é parar de se pesar. Eu nunca mais me pesei, eu não sei quanto eu peso. Eu acho isso muito bom, porque isso vai tirando nossa neurose com relação a isso. Essa coisa da balança era mais uma coisa que ativava muito pra mim a coisa da compulsão, porque te deixa nervoso, te deixa neurótico com aquele número que não quer dizer nada. Eu me lembro muito... eu tenho essa foto em algum lugar, depois eu te mostro... é uma foto minha quando eu tava na faculdade... eu não sei meu peso hoje, mas acho que não mudou muito, e eu tava pesando exatamente a mesma coisa que eu tava pesando agora da última vez que eu me pesei.

Como exposto acima, é forçoso reconhecer que a importância da militância na vida das entrevistadas. Muitos estudos que buscam investigar o impacto de movimentos que advogam pela aceitação do corpo gordo, em contraponto à busca da magreza, comumente deixam de lado os relatos de quem experimento a realidade dessa condição: as pessoas gordas. Se a finalidade é a melhoria da qualidade de vida dessa população, fazse necessário incluir a voz dessas pessoas nos estudos sobre obesidade. 


\section{CONSIDERAÇÕES FINAIS}

Desde muito cedo na minha vida que me interessa a questão da normatização do corpo e, como consequência, da alimentação, dos hábitos, da vida, enfim. O que as pessoas entendiam por saúde parecia entrar em conflito direto com a busca por uma vida guiada pelo prazer, como diz na canção famosa "será que tudo que eu gosto é ilegal, imoral ou engorda? ${ }^{25 "}$. Esse interesse-inquietação se aprofundou no meu mergulho na cozinha, e com isso, me perguntava: a promessa da saúde perfeita acabou com o prazer de comer? Se o mundo repetia sem cansar que engordar era umas das piores maldições a cometer por alguém, não restava dúvidas de que a resposta era sim.

Ainda assim, existiam certas contas que não fechavam. Se a maioria parece se engajar na busca da saúde perfeita (ou pela magreza), porque ainda assim, continuamos a engordar? Se essa busca é pela saúde, porque as consequências (anorexia, bulimia e compulsão) dela são tão danosas? Não existe justificativa possível para a estigmatização planejada sobre o corpo gordo. Já são muitas décadas de "guerra à obesidade" e os problemas só se agravam. Conceitos como "epidemia da obesidade" só tem como função mascarar o fato de que as populações mais pobres têm a sua vida cada vez mais degrada, inclusive no que diz respeito à alimentação.

Não muito tempo depois, entrei em contato a militância gorda. Encantado, tive a impressão de ter encontrado tudo que parecia faltar: a rejeição da normatização da vida e a busca pela produção autônoma e livre dela. Estava, em parte, certo. A militância gorda, enquanto produção coletiva, rejeita o ideal magro de normalidade e saúde. Os indivíduos ali inseridos não pensam a si, como pessoas gordas, desviantes e doentes e buscam, de diversas formas, produzir outras formas de vida, para além das normatizações existentes. Porém, trata-se de um movimento um tanto mais complexo.

Antes de iniciar a pesquisa de campo, eu assumia que a militância se opunha integralmente ao discurso hegemônico sobre o corpo gordo. No entanto, ainda que para alguns indivíduos isso seja verdade, a coletividade assume alguns pontos de vista do saber biomédico, como a impossibilidade de ter saúde com um corpo gordo.

Fica claro o entendimento de que, apesar da necessidade de lutar contra a estigmatização desses corpos, é urgente evidenciar que muitas pessoas estão morrendo. No plano simbólico, morrem quando assumem para si que são pessoas preguiçosas,

\footnotetext{
${ }^{25}$ Roberto Carlos, Imoral, ilegal ou engorda.
} 
irresponsáveis ou coisa que o valha, sendo moralmente culpadas por sua gordura. Concretamente, como mostram os depoimentos das entrevistadas, as pessoas gordas, consideradas obesas, estão morrendo por falta de acesso ao trabalho, à saúde, ao transporte, ao lazer, ao amor. Estão morrendo porque muitos vivem reclusas em casa, morrendo porque as que ousam estar no mundo, são hostilizadas quando fogem do padrão considerado normal, em nossa época. Estão morrendo porque quando procuram pela instituição médica, são por ela violentados. E é nessa luta pela vida e pela não sujeição que a militância antigordofobia se mostra fundamental. 


\section{REFERÊNCIAS}

Adam, Philippe. Herzelich, Claudine. Sociologia da doença e da medicina. Bauru, SP: Edusc, 2001.

Basham, P. Luik, J. Is the obesity epidemic exaggerated? Yes. BMJ, 2008.

Bell, Kirsten. McNaughton, Darlene. Feminism and the Invisible Fat Man. Body \& Society. SAGE Publications (Los Angeles, London, New Delhi and Singapore), Vol. 13(1): 107-131>, 2007.

Bray, George A. Bouchard, Claude. Handbook of Obesity. CRC Press, 2004.

Bray, George A. History of Obesity. IN: Obesity: Science to Pratice. (eds G. Williams and G. Frühbeck), John Wiley \& Sons, Ltd, Chichester, UK, 2009.

Breton, David Le. Antropologia do Corpo. Petrópolis, RJ. Vozes, 2011.

Breton, David Le. Sociologia do Corpo. Petrópolis, RJ. Vozes. 2006

Carneiro, Sueli. Gênero, raça e ascenção social. Disponível em $<$ https://www.geledes.org.br/wp-content/uploads/2015/05/Gênero-raça-e-ascençãosocial.pdf $>$. Acesso em 10 de julho de 2019.

Canesqui, Ana Maria. Antropologia e alimentação. Rev. Saúde Pública, São Paulo, v. 22, n. 3, p. 207-216, jun. 1988 . Disponível em $<$ http://www.scielo.br/scielo.php?script $=$ sci_arttext\&pid $=$ S0034$89101988000300007 \& \operatorname{lng}=$ pt\&nrm=iso $>$. acessos em $08 \quad$ set. 2016. http://dx.doi.org/10.1590/S0034-89101988000300007.

Canesqui, Ana Maria. Garcia, Rosa Wanda Diez. Antropologia e nutrição: um diálogo possível. Rio de Janeiro: Editora Fiocruz, 2005.

Canesqui, Ana Maria. A Medicalização da Vida como estratégia de biopolítica. Ciênc. saúde coletiva, Rio de Janeiro, v. 20, n. 6, p. 1961-1962, June 2015 . Available from 
$<$ http://www.scielo.br/scielo.php?script=sci_arttext\&pid=S1413-

$81232015000601961 \& \operatorname{lng}=\mathrm{en} \& \mathrm{nrm}=\mathrm{iso}>$.

access

on 04 Sept. 2017. http://dx.doi.org/10.1590/1413-81232015206.13022014.

Canguilhem, Georges. O normal e o patológico. Rio de Janeiro: Editora Forense Universitária, 2009.

Crenshaw, Kimberle. A Intersecionalidade na Discriminação de Raça e Gênero. Disponível em <www.acaoeducativa.org.br/fdh/wp-content/uploads/2012/09/KimberleCrenshaw.pdf $>$. Acesso em 10 de Julho de 2019.

Conrad, Peter. Schneider, Joseph W. Deviance and Medicalization: From Badness to Sickness. Temple University Press, Philadelphia: 1992.

Conrad, Peter. Medicalization and social control. Annual Review of Sociology, v. 18. 1992

Conrad, Peter. The Medicalization of Society: On the Transformation of Human Conditions into Treatable Disorders. The Johns Hopkins University Press: 2007.

Da Matta, Roberto. O ofício do etnólogo. Ou como ter anthropological blues. 1978. Rio de Janeiro.

Day, Jemma. Ternouth, Andrew. Collier, A. David. Eating disorders and obesity: two sides of the same coin?. 2011

Eknoyan, Garabed. A History of Obesity, or How What Was Good Became Ugly and Then Bad. 2006

Eknoyan, Garabed. Adolphe Quetelet (1796-1874) - the average man and indices of obesity. 2008

Fischler, Claude. El (H)omnivoro. Barcelona: Anagrama, 1995. 
Fischler, Claude. Gastro-nomía y gastro-anomía. Sabiduría del cuerpo y crisis biocultural de la alimentación moderna. 2010.

Fischler, Claude. Comer: alimentação dos frances, outros europeus e americanos. São Paulo: Senac. 2010.

Fischler, Claude. Commensality, society and culture. Social Science Information: 2011

Flandrin, Jean-Louis. Montanari, Massimo. História da alimentação. São Paulo: Estação liberdade. 2015

Foucault, Michel. A ordem do discurso: aula inaugural no Collège de France, pronunciada em 2 de dezembro de 1970. São Paulo: Edições Loyola, 2014.

Garcia, Rosa Wanda Diez. A comida, a dieta, o gosto: mudanças na cultura alimentar urbana.

Goldenberg, Mirian. Cultura e gastro-anomia: psicopatologia da alimentação cotidiana. Entrevista com Claude Fischler. Horiz. antropol., Porto Alegre , v. 17, n. 36, p. 235-256, Dec. 2011 Available from $<$ http://www.scielo.br/scielo.php?script $=$ sci_arttext\&pid $=$ S010471832011000200010\&lng=en\&nrm=iso $>$ access $\quad$ on 15 Sept. 2016. http://dx.doi.org/10.1590/S0104-71832011000200010.

Goldenberg, Mirian. "A comida como objeto de pesquisa": uma entrevista com Claude Fischler. Psicol. clin., Rio de Janeiro , v. 23, n. 1, p. 223-242, 2011 . Available from $<$ http://www.scielo.br/scielo.php?script=sci_arttext\&pid=S010356652011000100014\&lng=en\&nrm=iso $>$ access on 15 Sept. 2016. http://dx.doi.org/10.1590/S0103-56652011000100014.

Goffman, Erving. Estigma: notas sobre a manipulação da identidade deteriorada. Editora LTC, 1988.

Haslam, D. Obesity: A medical History. 2006 
Komaroff, Marina. For Researchers on Obesity: Historical Review of Extra Body Weight Definitions. Journal of Obesity. 2016

Kraemer, Fabiana Bom. O discurso da alimentação saudável como estratégia de biopoder. Physis Revista de Saúde Coletiva, Rio de Janeiro, 2014.

Laplantine, François. Antropologia da doença. São Paulo: Martins Fontes. 2014

Maciel, Maria Eunice. Cultura e alimentação ou o que tem a ver os macaquinhos de Koshima e Brillat-Savarin. Porto Alegre, ano 7, n. 16: 2001

Ministério da saúde. Guia alimentar para a população brasileira. Brasília: 2006.

Mintz, Sidney. Du Bois, Christine. The anthropology of food and eating. Annu. Rev. Anthropol. 2002

Montanari, Massimo. Comida como cultura. São Paulo: SENAC SP. 2013

Nye, Robert A. The evolution of the concept of medicalization in the late twentieth century. IN: Journal of History of the Behavioral Sciences, Vol. 39(2), 115-129 Spring 2003

Oliver, Eric J. The Politics of Pathology: How Obesity Became an Epidemic Disease. Perspectives in Biology and Medicine, Volume 49, Number 4, Autumn: 2006

Oliveira, Régia Cristina. Corpo, gênero, adolescência: discursos e (re)significações a partir da anorexia e da obesidade. Revista Latinoamericana de Estudios sobre Cuerpos, Emociones y Sociedad - RELACES, Nº, Año 4. Agosto-noviembre de 2012. Córdoba. ISSN: $1852.8759 . \quad$ pp. 17-27. Disponível em: http://www.relaces.com.ar/index.php/relaces/article/view/170

Poulain, Jean-Pierre and Proença, Rossana Pacheco da Costa. O espaço social alimentar: um instrumento para o estudo dos modelos alimentares. Rev. Nutr. [online]. 2003, vol.16, n.3 [cited 2016-09-14], pp.245-256. Available from: 
$<$ http://www.scielo.br/scielo.php?script=sci_arttext\&pid=S1415-

$52732003000300002 \& \operatorname{lng}=$ en\&nrm $=$ iso $>$. ISSN

$1678-9865$.

http://dx.doi.org/10.1590/S1415-52732003000300002.

Poulain, Jean-Pierre and Proença, Rossana Pacheco da Costa. Reflexões metodológicas para o estudo das práticas alimentares. Rev. Nutr. [online]. 2003, vol.16, n.4, pp.365-386. ISSN 1678-9865. http://dx.doi.org/10.1590/S141552732003000400001 .

Poulain, Jean-Pierre. Sociologia da Obesidade. São Paulo, SP. SENAC-SP, 2013.

Rosengrena, Annika. Lissner, Lauren. The Sociology of Obesity. 2008

Rosa, Tereza Etsuko da Costa; Benicio, Maria Helena D'Aquino. As redes sociais e de apoio: o conviver e a sua influência sobre a saúde. BIS, Bol. Inst. Saúde (Impr.), São Paulo, n. 47, abr. 2009 . Disponível em $<$ http://periodicos.ses.sp.bvs.br/scielo.php?script=sci_arttext\&pid=S1518$18122009000200021 \& \operatorname{lng}=$ pt\&nrm=iso $>$. acessos em 14 jul. 2019.

Russo, Jane. Do corpo-objeto ao corpo-pessoa: desnaturalização de um pressuposto médico. IN: Souza, Alicia Navarro de. Pitanguy, Jacqueline. Saúde, corpo e sociedade. Rio de Janeiro: EDITORA UFRJ, 2006.

Santos, Ligia Amparo dos. O corpo, o comer e a comida. Salvador: EDUFBA. 2010

Scott, Joan. Gênero: Uma categoria útil de análise histórica. 1995

Truswell, Arthur S. Medical History of Obesity. Nutrition and Medicine: 2013.

Vigarello, Georges. As metamorfoses do gordo: história da obesidade no ocidente. Petrópolis, RJ. Vozes, 2012.

Williams, Gareth. Frühbeck, Gema. Obesity: Science to Practice. 2009. 
Wanderley, Emanuela Nogueira; Ferreira, Vanessa Alves. Obesidade: uma perspectiva plural. Ciênc. saúde coletiva, Rio de Janeiro, v. 15, n. 1, p. 185-194, Jan. 2010 Available from <http://www.scielo.br/scielo.php?script=sci_arttext\&pid=S1413$81232010000100024 \& \operatorname{lng}=$ en\&nrm=iso $>$. access on 26 Sept. 2017. http://dx.doi.org/10.1590/S1413-81232010000100024. 


\section{ANEXO A - ROTEIRO DE PERGUNTAS}

Grupo de perguntas em relação a questão corpo

E: O que você pode me falar sobre a relação com seu corpo ao longo da sua vida?

$\rightarrow$ E quando você conheceu a militância, como foi?

$\rightarrow$ E em relação à médicos, o que você pode me dizer sobre essa questão?

$\rightarrow$ Como foi esse momento de se auto afirmar como mulher gorda?

$\rightarrow$ Pensando em toda essa história, como você percebe esse corpo?

$\rightarrow$ Você pode comentar sobre a diferença entre gorda e gordo e obesidade?

Grupo de perguntas em relação a questão comida

E: Você pode me contar sobre sua relação com a comida ao longo da sua vida?

$\rightarrow$ O que você pensa sobre dietas?

$\rightarrow$ Sobre essa questão da alimentação saudável, o que você pensa?

$\rightarrow$ Você já foi a um nutricionista? Se sim, pode me falar sobre isso?

$\rightarrow$ O que a comida e comer significam para você hoje?

Grupo de perguntas em relação ao discurso biomédico

E: Você pode em falar um pouco mais sobre sua relação com o que é dito pela medicina? Pensando especificamente sobre a questão do corpo gordo.

$\rightarrow$ Como você percebe a relação de pessoas gordas com profissionais de saúde?

$\rightarrow$ Você pode comentar a relação com esses profissionais após você fazer parte da militância?

$\rightarrow$ Pensando sobre nutricionistas especificamente, como você percebe a atuação desses profissionais em relação a pessoas gordas?

$\rightarrow$ É muito comum se falar em epidemia da obesidade ou que obesidade é uma doença. O que você acha sobre isso? 


\section{ANEXO B - ENTREVISTA COMPLETA}

\section{ENTREVISTA SIMONE}

Eu acho maravilhosa. Dura, é árdua, não a relação que eu tenho com as meninas, mas o

próprio movimento mesmo. É um movimento de resistência, assim. É... Mas, hoje, é... Eu me sinto maravilhosa. Eu me vejo... Eu busco na minha memória a Simone de antes e a Simone de hoje. E eu não trocaria por nada. Hoje eu tenho o mesmo peso de antigamente, de um 5 anos atrás... Mas a diferença, minha postura, diante de mim, diante do meu corpo, diante dos meus amigos, diante dos meus relacionamentos, realmente amorosos, diante da minha família, diante de todo mundo que vem questionar por eu seu gorda, porque eu que eu não emagreço, que vem com receita... a minha postura é outra, antigamente eu me escondia, antigamente eu não me via desejável, é totalmente diferente. E é muito bom a Simone que eu me tornei.

Eu me odiava, essa é a palavra. Conversando uma vez com minha melhor amiga, que é desde sempre que a gente tá junta, ela falava: Simone eu não percebia isso! Mas era porque eu vivia na clandestinidade... Eu odiava meu corpo mas não podia dizer porque eu me sentia inferior, eu me sentia feia, eu achava que nada ficava bom em mim, eu queria vestir preto, eu só queria vestir cores que eu me escondesse, e eu realmente escondia meu corpo porque o tempo todo as pessoas estavam me criticando, né... E o que mudou em relação ao meu corpo é que eu percebi que eu nunca me incomodei... Eu não tenho uma memória de dizer, "ah, eu me incomodei com meu corpo", na verdade o que me incomodava e o que incomoda são as outras pessoas falando do meu corpo... E hoje minha relação é ótima, eu acho, lógico que... eu acho natural... tem partes do meu corpo que eu não gosto... mas a diferença é que eu não deixo de sair, não deixo de curtir, eu não deixo de me relacionar com uma outra pessoa, no escuro, porque eu tenho vergonha do meu corpo, lógico que eu gostaria de mudar, mas eu não vivo obsessiva, deixando de comer as coisas que eu gosto, deixando de ir para os lugares que eu gosto, porque eu não posso comer e minha barriga vai crescer e eu vou engordar. Essa é a mudança, eu mudei a relação com meu corpo... hoje eu consigo, eu não me olhava no espelho... é... eu não me pesava porque eu tinha medo de ver e se tivesse acima de $50 \mathrm{~kg}$, eu tava exageradamente gorda... e eu não gostava de me ver no espelho... e hoje eu gosto do que eu vejo no espelho, hoje eu gosto da roupa, que... que eu visto, hoje eu entendo que o problema não tava no 
meu corpo, o problema é que não existia e não existe ainda roupa acessiva para mim, enquanto mulher gorda. Às vezes as minhas amigas me marcam em coisas e quando eu olho, até 52 . Eu visto 58, né... a maioria das minhas amigas veste mais que 60, entende? Então na verdade o problema não é o meu corpo são as coisas que não estão acessíveis a mim, ainda.

Assim, eu tenho uma, é... Qual a palavra... Uma quebra na minha vida que foi o falecimento de minha mãe. Faltou a palavra agora... O divisor de águas que foi o falecimento de minha mãe... minha mãe faleceu quando tinha 17 anos... e eu era uma criança, na verdade. Na verdade eu tinha a mente de 13 anos... e eu justamente tava na adolescência, que você tá se descobrindo, você não sabe o que você quer, você não sabe o que você quer como profissão, você não sabe o que você quer fazer, você não sabe... você não sabe praticamente nada... e... minha mãe faleceu neste momento e ficou tudo muito confuso, e... na minha cabeça, e... e nesse crescimento o meu corpo era muito visível, eu sempre fui muito grande e gorda para os padrões e eu fiquei meio que perdida entre o falecimento de minha mãe, que é essa perda, e... é... a questão da gordofobia que naquele momento eu não entendia, né... aí minha vó, que tomava conta de mim, me protegia demais, também tem essa parte, não deixava sair, não deixava ir para os lugares, e eu comecei a, sabe, tava explodindo já, porque eu queria sair, eu queria viajar, é... eu não me sentia bem com meu corpo por ser realmente gordo, então foi tudo meio que misturado, foi uma fase mesmo da adolescência... E aí eu comecei, eu gosto muito de psicologia, eu comecei a procurar saber, eu ficava ansiosa, eu... minha vó falava as coisas comigo, eu ia pro quarto chorar, eu comia exageradamente pra tentar me saciar, saciar minhas emoções, os meus, as coisas que eu não conseguia... e aí eu comecei a pesquisa sobre ansiedade e tal, e aí fui parar na questão da cirurgia bariátrica, né... que seria um sonho, né. Porque é o que é vendido, é a sensação de liberdade, que você passa a ser a dona do seu corpo, e... vem os elogios das outras pessoas, nossa, você emagreceu e tal... aí na época eu tinha um plano e eu fui tentar a cirurgia bariátrica. Foi o meu primeiro passo, assim. E aí quando chegou lá eu sabia que ia... que a psicóloga poderia me barrar, e ela me barrou. Porque eu fiz todos os exames, passei pela nutricionista, passei pelo cirurgião, mas quando chegou ela trazia perguntas e me fez questionários que... é... eu respondi os questionários, que tinha questionamentos que pra mim eram bobos, mas... é... ela foi me pegando, sabe? Eu lembro de uma pergunta: "você sente vergonha de comer na frente dos outros?" Sim, porque o gordo tá sempre como o que come mais, como que 
é comilão, sendo que às vezes eu nem como a mesma quantidade que o outro, né. Eu como porque eu gosto porque eu gosto de comer, como porque a comida é gostosa, sabe? Sabe, chega natal, chega ano novo, chega São João, que são comidas típicas e todo mundo quer comer exageradamente porque são comida específicas... e pra mim não, eu ficava com vergonha de comer na frente dos outros, e... minha família não tava querendo que eu fizesse porque tava com medo, porque é uma cirurgia, com medo de eu morrer e tal, monte de coisa... E ela foi que meio que cortando, me podando, até que eu desisti e eu hoje acho que foi a melhor coisa na verdade que aconteceu... porque eu realmente o que eu achava não é verdade, eu achava que minha vida iria mudar, que eu iria ser mais feliz sendo magra e que as pessoas iam me aceitar, que eu ia conseguir me posicionar, porque o centro da minha vida era que tudo que acontecia era porque eu era gorda... seu tomasse uma topada foi porque eu sou gorda, né. Mas eu costumo dizer que o que eu sentia não era mentira não, era tudo real.

Essa semana mesmo no trabalho, minha amiga, ela não é gorda, ela tá com os pés muito inchados, aí eu falei assim coma ela assim, fiquei preocupada "poxa cê tá com o pé inchado" aí ela "Simone, eu fui no médico e o médico disse que eu tô gorda, porque eu engordei" aí eu "isso é mentira", no máximo ela tá com sobrepeso, mas mesmo que fosse por causa do sobrepeso ele tinha que parar pra fazer um exame. Aí eu, sabe? Eu fico chateada, porque eu que tenho que parar, a gente lá no trabalho, falei assim "você tem que se realmente se preocupar com seus pés inchados, você tem que procurar um especialista, um angiologista", sabe? Eu fico preocupado com pessoas, com meninas, que não tem nenhum acesso, que como eu, engolia tudo que o médico dizia, tudo que qualquer pessoa dizia: "você tá assim porque você tá gorda", entende? E eu sentar com ela pra dizer "realmente, seus pés estão inchados, pode ser uma coisa vascular, na aorta, pode ser um vaso importante, que não tá passando sangue", nas antigamente não tinha isso, antigamente é porque você tá gorda e acabou, entende? E até minha mãe mesmo, meus próprios familiares falavam tudo isso, é... a gente não achava roupa pra mim... antigamente era muito mais difícil achava roupa... não achava roupa pra mim porque eu era gorda... não porque não tinha roupa, eu não tinha acesso a roupa... além de gorda eu também era muito grande. Não achava sapato, aí também porque eu era gorda... eu sou grande, é... as numerações maiores nunca foi, é... tão acessíveis, né... todo mundo tinha que ter aquele pé pequeno, aquele pé princesa... tudo isso ao mesmo não era fantasia da minha cabeça, eram coisas reais que eu sentia. E aí eu terminei desistindo, ela mandou 
procurar um psicólogo, eu procurei um psicólogo na minha cidade... a psicóloga disse que não via necessidade de eu fazer... e por coincidência, nesse turbilhão, eu tinha... eu tava fazendo faculdade de pedagogia e no IFBA lá de Santo Amaro... E por coincidência ou não lá no IFBA tinha a psicóloga, né, que você poderia solicitar... E aí foi... ah... o ponto alto, assim... foi o meu ápice, que eu ia nas sessões com ela, e ela muito interessada, ela me ajudou muito, muito muito, muito muito, tinha época que eu chegava lá chorando... porque era muito ruim, muito ruim a sensação que eu sentia (chorando), sabe, assim... brigava muito com ela.. "Andrea, aconteceu isso..." ela "Simone, não é assim...". Uma coisa que ela sempre falava que eu hoje eu realmente percebo é que tem que ser uma coisa que realmente vem de dentro, que quando você se sente realmente bonita, isso transfere para as outras pessoas... Lógico que vai ter sempre alguém que vai dizer alguma coisa... Mas quando você se sente bonita, quando você se sente firme no que você faz e no que você fala, as pessoas já começam a te olhar de outro jeito... mas só que eu brigava muito com ela... dizendo "Andréa, aconteceu tal coisa porque eu sou gorda" eu não consegui... eu achava que as minhas amizades estavam comigo por pena de mim... por eu ser gorda.. e eu aceitava tudo que elas faziam... assim, besteira, sabe, Luis? Assim, de... ah, você me falava alguma coisa que eu não gostei, mas eu não falava nada a você porque eu ficava com medo de você terminar a amizade comigo... porque você estava comigo por eu ser gorda, porque você estava com pena... e eu nunca discernia que a amizade que eu oferecia era muito boa e é muito boa independente do meu corpo, né? Porque hoje eu penso diferente, hoje eu penso que eu, que todo mundo tem que ter respeito ao meu corpo porque é o meu corpo que sustenta as minhas ideias e tudo que eu ofereço... Seja de bom, seja de ruim, é meu corpo que guarda minhas emoções e que me sustenta, entende? Essa parte também mudou e Andréa foi também sensacional... Muito me ajudou, bastante... Aí eu ia sempre para as sessões, chegava lá arrasada em relação aos meus relacionamentos também... eu achava que o cara tinha que ficar... que eu teria que ter a sorte de encontrar um cara que não se importasse por eu ser gorda... Aí nesses momentos de transição um amigo meu me ajudou bastante... É... ele.... Eu tava nesse processo da cirurgia bariátrica, ele foi a única pessoa que chegou realmente e falou assim "Simone, é o que você quer? E o que importa, entende? Não vou julgar se tá errado ou se tá certo. Eu vou te apoiar". Aí quando eu saia arrasada das sessões, com a psicóloga da cirurgia bariátrica, ele tava lá, me ajudava... aí eu terminei confundindo as coisas, achando que tava apaixonada por ele naquele momento... Aí eu falava isso com ela... e ela tentando... é... mostrar... porque ele sempre foi muito solicito, sabe? Eu conversava com ele, falava um monte de coisa, falava 
das minhas angústias... Aí ela falando... uma das outras coisas também... As coisas que ela falava eram muito fortes pra mim... Ela falava tipo "Simone, que tipo de homem você quer? Que esteja ao seu lado... um homem que não gosta de você por causa do seu corpo, não respeita o seu corpo..." Que é uma coisa que hoje eu levo pra minha vida, entende? Lógico que eu encontro que eu encontro ainda que não gostam... que não me querem por eu ser gorda... Existe milhares... mas eu não posso ficar presa a eles, a esse tipo de demanda... Eu tenho que estar com os que querem ficar comigo... e também, hoje, eu acredito e vejo que tem homens que gostam de mim por eu ser especificamente gorda, né? Coisa que eu não acreditava, como eu falei... eu achava que que tinha que achar uma pessoa que me aceitasse, que não se importasse, e que eu tinha que ficar com essa pessoa porque ela estava fazendo um favor pra mim... Aí minhas relações sempre foram muito assim, sempre foram muito tardia por causa também do machismo que fui criada, mas também muito por causa dessa coisa de eu ser gorda e eu senti que não me importava, né? Todo mundo tava beijando mas ninguém queria ficar comigo porque eu era gorda, eu era Simone amiga de todo mundo, mas ninguém queria ficar comigo na rodinha porque eu era gorda... e isso tudo era muito velado... aí eu volto a falar... não é... não é loucura da cabeça da mulher gorda...de dizer "ah, ninguém gosta de mim, ninguém fica comigo porque eu sou gorda.", não é loucura... realmente existe uma demanda e existe um grupo que não gosta da gente porque a gente é gorda... quando a gente está na rodinha a gente é preterida por não ser... por ser gorda, entende? As pessoas não escolhem a gente porque a gente é gorda... "Ah, tá mais acessível, não sei o quê..." mas eu não tou falando de gordinha, estou falando de mim que sou gorda, que sou esteticamente, é... distante até do padrão que é estabelecido plus size, que você sai daquela magreza, mas tá gordinha, que tem um pouquinho de peito, que tem um pouquinho de coxa, que tem um pouquinho de bunda...

A estrutura do corpo gordinha é uma menina que engordou um pouquinho, né? Que tem um pouquinho de barriga, que tem um pouquinho de peito, e eu não... eu sou gorda, minha barriga é grande, sabe? Eu conheço umas meninas que tem os peitos maiores... e tem... e também... tudo muito fora do... daquele outro padrão, né? Que é o que a gente luta também. A gente não quer sair de um padrão, do padrão de magreza pra entrar em outro padrão que seria o padrão plus size, né? Que são meninas que tem a barriga mais enxuta, e tem aquele quadril largo, tem a coxona, tem os seios mais avantajados, a diferença é estrutura do corpo mesmo. Aí tem algumas pessoas que falam "ah, gordinha", né? A 
palavra gorda também, né? A gente tá tentando desmistificar mesmo, né? Que não tem nenhum problema em você ser gorda, né? Não... é... gordinha, fofinha... essas coisas, né? Pra tentar amenizar uma coisa que não é problema, né? O meu corpo é gordo e ponto. $\mathrm{E}$ ponto.

Foi... Foi aí mais ou menos assim... Não sei se já foi no final... Eu já tava bem melhor, assim... outra coisa que eu percebo assim. Eu comecei a me... Porque assim, as pessoas dizem assim "não adianta você colocar um brinco porque você é gorda. Não adianta você passar um batom porque é gorda". Num desses encontros recentemente a gente tava com uma menina, a menina falou assim "Poxa, a mulher tava fazendo minha unha, disse, recebeu um whatsapp de uma outra mulher e disse assim, a manicure dizendo "não sei porque fulana que fazer a unha " a menina é gordinha, é gorda e tava querendo fazer a unha, a manicure falou "eu não sei porque fulana quer fazer a unha se ela é gorda". Aí veio a voz de lá do fundo da minha amiga e falou assim "você... você tem que parar de fazer a unha com essa mulher" e não sei o que, entende? Porque antigamente pra mim eu ia... é... não preciso fazer a unha porque eu sou gorda e hoje eu já tenho outra postura... hoje eu concordo com minha amiga, quem vai deixar de fazer a unha com ela sou eu. Aí ela disse "ah, não... ela disse que eu não, que não sei que" ela disse "não, tá falando, tá falando da mulher gorda, tá falando de mim também”. E aí, eu... hoje eu percebo que quando... assim... eu não me arrumava, eu não pintava minha unha, não vestia uma roupa bonita, porque eu achava que... era gorda, não tinha necessidade, não ia... não ia fazer nenhum tipo de mudança. E aí eu peguei amizade com uma menina, e eu tava no facebook, naquele... bem... bem... primário mesmo, aí subiu... uma postagem, assim, é... "fulana comentou no grupo 'Gordinhas lindas da Bahia", aí eu "É o que que essa menina quer? Ela tá maluca? Grupo de meninas gordas... que loucura!”... E aí eu peguei e fui olhar e tinha um monte de postagem, assim... Aquelas postagens de... de incentivo, de... de coisa... tinha muita coisa de discussão e eu comecei a escrever também... porque... eu tava... eu tava no princípio, né? Eu tava realmente estudando... a psicóloga da cirurgia bariátrica foi muito fabulosa porquê... quando ela mandou ela pesquisar sobre cirurgia bariátrica... Eu entrei nesse mundo, né? Do mundo gordo, do que era real... do que era mentira, do que era ser gordo, do... do... do que não era, entende? Então eu tava vindo com uma construção... Com uma carga muito boa, assim... de realmente... e eu tava lendo algumas coisas... hoje eu mesmo... de realmente ser eu, de ser o que eu quiser ser, né? Independente do meu corpo. E aí eu comecei a conversar com as meninas, eu peguei 
amizade com Cecília, que é Cecília Maria, aí comecei a pegar amizade com as meninas... Viviane também me ajudou. Cecília foi o primeiro impacto porque eu vi mulheres reais, assim, sabe? Porque pra mim a mulher gorda era uma mulher que... Não podia ser bemsucedida, sabe? Bem-sucedido é você que está num corpo magro, independente de qualquer coisa... Você estando num corpo magro você seria bem-sucedido. E eu não vi muita coisa de diferente nas mulheres, né? São mulheres comuns, mas que trabalham, que estudam, que namoram, que são casadas, que tem filhos... Eu cheguei mais próxima de homens que gostam realmente, é... do corpo gordo, da mulher gorda... então isso tudo, me abriu um mundo que eu não conhecia um mundo... foi... ó... que foi ocultado de mim... na verdade minha família não conhecia, né? Ninguém de lá de Santo Amaro conhecia e eu acho que até hoje não conhecem... acha que a pessoa que tá junto, porque gosta... é muito oculto para... as... para os caros que eu fico lá em Santo Amaro... São raros os que chegam pra dizer que gostam de mulheres gordas, se declaram gostar de mulheres gordas... é uma coisa meia assim, meio oculta... Não sei ainda se por vergonha ou se por... por achar que é, tipo... normal, "ah, é mulher mesmo", não saber da importância, entende? Mas aí foi mais ou menos... mas ou menos assim. E aí a gente se aproximou, é... as meninas já tinham algumas ideias... Cecília tem uma militância muito antiga do Orkut, assim... Com algumas meninas, e é... assim de militância que ultrapassa a beleza, a questão estética, né... a questão da beleza, de realmente ajudar muitas meninas, que ficam deprimidas, ficam depressivas, por comentários, por coisas... e Cecília tá sempre ali, tá sempre ajudando. Eu amo o grupo, assim... porque eu me reconheço muito nas meninas, e... eu fico assim olhando, essa questão mesmo, sabe, Luis, coisas básicas, que pra mim... não existia, sabe? De ver que a mulher gorda pode estudar, que ver que uma mulher gorda pode ter um filho, pode ter um marido, pode ter... pode estar bem no casamento... lógico que o casamento pode ter um monte de problema... mas não como eu pensava, de... "ah, porque... porque tá fazendo favor. Tá porque é uma pessoa caridosa. Tá com aquela mulher gorda, mas tá pegando um monte de outras mulheres... Porque ela é gorda...”. Lógico, que pode tá pegando um monte de mulher, mas ele tá pegando um monte de outra mulher porque ele é descarado, entende? Mas pra mim não, mas pra mim não, ah "ele tá fazendo um favor de ficar comigo, porque eu sou gorda... eu tenho que aceitar se ele beber, se ele não quiser nada com a vida, porque ele tá fazendo um favor", entende? Hoje eu vejo que não, hoje eu vejo que esses homens estão com essas mulheres porque querem, né? Elas tendo uma vida independente de qualquer coisa... e isso pra mim é maravilhoso... é assim, uma referência.... e Cecília principalmente eu sempre falo porque Cecília é, além 
de gorda, é negra... Que é... bem... isso pesa muito também. Uma mulher gorda e é branca, e é mais clara, assim, você percebe às vezes... eu percebo comentários de amigos meus, que não fazem em relação a mim por eu ter a pele mais clara... mas quando é uma mulher gorda e negra fica fazendo tipo chacota... e Cecília é muito incisiva, é muito inteligente... Em referência a isso, a militância e a vivência mesmo... Ela tem muito mais vivência do que eu... Falei demais?

É... foi daí que eu conheci as meninas, é... porque existe esse grupo "Gordinhas lindas da bahia - oficial" porque ele é mais, assim, mais de paquera... As meninas postam foto, às vezes a gente posta algum vídeo, posta alguma foto... aqueles discursinhos, né? É... aqueles memes, aqueles discursos, tal... Mas só, por trás, existe esse grupo que é o Movimento Gordo da Bahia que a gente de alguma maneira tá tentando fomentar e trazer... porque, assim... a estética é muito vaga, muito efêmera, muito passageira... a gente quer fortalecer a mulher para que em qualquer lugar que ela esteja... porque uma coisa é muito fácil, eu estar no meu grupinho, sabe? Sabe aqueles grupinhos de gangue, que você chega, você bate em todo mundo, você picha, você quebra carro, não sei o que... mas quando você tá sozinha, quando é só você, eu acho que o nosso objetivo é justamente isso, entende? Não entende eu falar que ser... que ser gorda é bom, ser gorda é bonito se... quando alguém faz algum comentário eu saio chorando. Eu deixo de comprar um roupa que eu quero porque eu sei que alguém vai comentar, sabe? (inaudível). Lógico que eu tenho minhas preferências como eu falei. Eu tenho minhas preferências de vestido, eu tenho minhas preferências de short, de bermuda, mas nunca que vou deixar de ter uma coisa somente porque eu sou gorda, entende? Isso mudou muito. E é isso que a gente quer. A gente quer que a mulher gorda ela realmente possa fazer as escolhas e faça as escolhas sozinha... porque às vezes não dá tempo, às vezes eu tô aqui com você e você fala uma coisa e não dá tempo de eu chamar as meninas, não dá tempo de eu me juntar. “Gente, vem aqui dá uma resposta a meu tio", entende? É isso como eu falei de Viviane a menina fez um comentário sobre a manicure... a gente, ó, imediatamente já sabe... é... é... teve um encontro muito importante que aconteceu, as meninas... aí a gente fomenta com palestra, com reuniões... porque eu falo com as meninas "a gente tem que fazer um motim mesmo, a gente tem que se juntar, a gente tem que começar a aprender a lidar. Porque o mundo lá fora quer engolir a gente, o mundo lá fora quer que a gente emagreça acima de qualquer coisa. E não respeita" É de pai, é de mãe, é da pessoa mais próxima, do seu marido, é da pessoa mais querida. Vem, e vem com tudo pra cima da gente. E se 
a gente não se proteger a gente termina enlouquecendo. E aí nessa palestra as meninas fizeram um ciclo de palestra e a... todo mundo falando um pouquinho de como agir. A minha amiga falando daqueles... poxa... que vende aqueles shakes... Que o homem chegou com um papelzinho dizendo que queria ajuda... que queria ajudar ela. Aí ela disse que pegou o cartão, jogou na cara dele, esculhambou o homem todo, que aí o pai dela, assim, olhando pra ela, mas, sabes? São atitudes que a gente precisa aprender a tomar, sabe? Tipo assim, você chegar com um cartãozinho dizendo que tem um ajuda pra mim, sabe? Eu te pedi, sabe? Meu corpo, você tem certeza que meu corpo é um problema? Então são coisas que a gente tem que se reunir, pra discutir, pra aprender. Se agora eu encontrar um homem da herbalife com certeza eu vou encontrar... não vou fechar, como ela fez... mas vou lembrar da atitude que ela teve. Por exemplo, comentários sobre a manicure. Eu não vou querer que uma pessoa me preste um serviço que diz que eu não preciso porque diz que eu sou gorda, entende? Então são coisas que a gente quando se junta, que a gente vai discutindo, que a gente vai aprendendo, sabe? Aí minhas amigas falam da questão do ônibus, que sentam no ônibus amarelo, que não saem de jeito nenhum. Que ali na cadeira amarela, porque ali é um lugar pra gente, independente de ter uma pessoa mais velha, de ter uma pessoa deficiente, ali também é um lugar para gente... então são coisas que a gente vai aprendendo, pra se fortalecer. Porque não vai ser sempre que a gente vai tá junto, né? Que pra mim esse é o grande... o grande problema e o grande risco, né? Porque as pessoas vão comentando as coisas assim, que as vezes eu fico... e... e cada um contando seu relato, eu ficava assim... outra coisa também, é... teve uma, Vivi, ela engravidou, ela tava grávida recentemente, acho que o menino não tem nem um ano. Passou por... é... aquela coisa obstetrícia... esqueci o nome... o preconceito... esqueci... violência! Violência obstetrícia... porque ela, ela é a mais gorda, bem mais gorda do que eu. Quando foi pra... é... quando descobriu que tava grávida, no primeiro dia que foi pro médico, o médico disse que ela tava tentando suicídio. Ele falou isso, que ela tava tentando suicídio. E aí, Vivi passou a gravidez toda péssima, muito mal, com medo de realmente morrer, com medo de perder o bebê por causa de um comentário de um médico. E aí no dia que ela foi parir a médica disse que o único risco dela era ser gorda, não existia nenhum tipo de problema, que era pra chegar cedo. Aí ela chegou 6 h da manhã, só foi parir $7 \mathrm{~h}$ da noite porque teve casos mais graves do que o dela. O único problema dela era ser gorda. Teve o menino dela normal, não teve problema nenhum. Mas por causa de um comentário de uma médica, Jana passou os noves meses da gravidez dela péssima, passando mal, passando muito mal, angustiada, nada parava no estômago por causa de um comentário. 
E o único problema dera era que é gorda, só. Aí foi cedão pra ter o filho, e foi protelando, protelando, aí foi só ter fillho $7 \mathrm{~h}$ da noite, porque estavam chegando casos realmente graves, que precisavam de de um parto de urgência, entende? Essa outra coisa, pra mim eu acreditava que eu como mulher gorda não podia ter um filho, né? "Ah, porque você é muito gorda, não vai conseguir um filho, natural", entende? Parece loucura mas eram coisas que me eram alimentadas... e aí quando eu vejo Jana que é uma gorda maior que eu, que consegue ter um filho, que consegue ter um filho naturalmente, é... e depois... fazendo sexo naturalmente, e tendo a pessoa natural... eu fico assim, sabe? É isso que eu quero mostrar pra outras pessoas, pra outras mulheres também, que eu sei vivem aprisionadas, sabe, ficam desesperadas, porque todo lugar que você chega. Essa essa semana mesmo eu fui comprar uns negócios lá em santo amaro, uma coisa de coisas naturais, eu gosto de comer... e aí a mulher... banana chips, aquelas bananas chips, aí eu peguei e falei assim "ah, quero banana chips" ela "você quer doce, você quer salgada?" aí eu disse a ela "quero natural" aí ela "ah, natural é boa porque emagrece, não sei o que" aí eu "eu gosto de natural porque é gostoso, porque eu gosto de comer tudo que é gostoso, não sei o que", aí... sabe? Ser uma pessoa... ensinar, pra não ser uma pessoa grossa, não ser uma pessoa mal-educada, eu disse "não, na verdade eu gosto de comer, eu gosto dessa porque é mais gostosa, é natural, a salgada às vezes vem muito salgada, eu não gosto" e eu já tinha levado um pouquinho de coisa doce, né? Aí tipo essa coisa de você tá o tempo todo tentando explicar a outra pessoa porque o que é vendido é que todo mundo tem problema com corpo, todo mundo tá tentando emagrecer, todo mundo, sabe? Aí às vezes eu tô assim, a pessoa fala assim "ah, menina tô tomando um chá, não sei o quê", eu pego, Luis, eu fico dura assim. Eu não tenho nenhum chá pra indicar, não tenho nenhum chá pra indicar. Eu tomo chá, gosto... eu gosto... eu não gosto... eu gosto de tomar chá, mas tem coisas, hábitos que são meus, que são hábitos alimentares da minha família, não é nada o tempo todo pra emagrecer, eu gosto de fruta, eu gosto de verdura, eu pego uma garrafinha de água, boto maçã, eu gosto de um monte de coisa, mas é porque eu gosto, não tenho nada de... a pessoa "pra que isso?", pra matar sede, pra, sabe?

É... porque você tem que ter uma explicação, porque você tá fazendo aquilo pra realmente emagrecer. Minha relação com a comida é maravilhosa. Hoje eu consigo entender que antigamente eu realmente... eu... eu me alimentava tentando saciar as minhas emoções, né? Quando eu era criança... Não... Quando eu era criança eu sempre fui uma criança muito mimada, então na minha casa tudo que eu queria eu tinha de muito exagero, né? 
Minha vó sempre, não sei se por ser... por sempre ser pobre e depois começar a ter... assim... condições um pouco mais... e... e por eu ser... eu fui criada por minha vó, por meu tio que nunca teve fillho, por minha mãe e meu pai que até o momento só tinha eu como filha... então eles não tinham muito dinheiro então tudo o que eu queria eles me davam, né? E minha família sempre foi muito comilona mesmo assim. E quando criança eu tinha tudo que eu queria, mesmo de comer, a questão da quantidade, de comer o quanto eu queria, sem... sem distinção nenhum. Eu comia tudo o que eu queria. E depois aconteceu isso da compulsão mesmo, alimentar. De quando eu ficar ansiosa, triste, eu ter que comer alguma coisa e quando eu fui, que eu passava com Andrea pelo IFBA que eu fui realmente descobrir a questão da compulsão alimentar, que eu não podia, que não deveria... qualquer sentimento que eu tivesse descontar na comida, né? E foi um hábito que eu terminei tendo mesmo. Se eu chorasse, se eu ficasse angustiada, se eu ficasse muito feliz, eu tentava não comer, né? E antes disso, passou um tempo quando eu tava tentando emagrecer, quando eu tava tentando fazer aquelas coisas, passou um tempo eu me trancava no meu quarto quando eu ficava muito chateada, porque minha vó também fazia muito isso, né? "Ah, você não pra tal lugar não que você... você não vai pra tal lugar não". Todos os meus amigos foram, todo mundo foi. "Você não vai pra tal lugar não". Aí eu não ia, mas aí enchia a geladeira de coisas que eu gostava, sabe? Na televisão tava passando aquele filme que eu gostava, entende? Como se realmente encaminhasse minha relação pra isso mesmo. Pra comida, pra questão da compensação. Você não teve tal coisa, mas vou te compensar com a comida, com dinheiro, com filme que você gosta. E aí depois que eu fui realmente descobrir e hoje, assim, é... Eu acho minha relação com a comida maravilhsa, porque... Sempre foi o centro da minha casa. Na minha casa meio dia a gente almoça. Quando eu vou pra Santo Amaro mesmo eu vou correndo pra ver meu avó, porque eu sei que meio dia ele vai tá lá sentando, comendo o almoço. Tem que tá, entende? E eu gosto muito de comer, tem coisa que eu gosto muito de comer. E pra mim, hoje, um dos meus maiores ganhos é... é... em relação a militância é poder assumir que eu gosto de doce. Eu gosto de comer chocolate, eu gosto de comer uma coisa exagerada e hoje eu percebi... e perceber que isso não é porque eu sou gorda, é porque eu sou uma pessoa natural, tem gente que gosta de um monte de coisa... eu tava vendo ali um stories ali da menina e a menina comprou um pote de maionese deste tamanho. Porque ela é apaixonada por maionese, aí eu tipo... 
Entende? Mas eu não entendia isso. Eu achava por eu gostar é porque eu era gorda, sabe? Se eu tiver um capricho é porque eu sou gorda, entende? E hoje não, hoje eu consigo compreender que é uma coisa que eu gosto. Eu falo assim com os meus amigos "eu não vou sentar ali pra comer duas, três acarajés" porque é uma coisa que eu não gosto, entende? Mas se eu sentar eu vou comer uma torta, vou comer um brigadeiro, vou comer um não sei o quê, porque realmente são coisas que eu gosto e eu consegui perceber isso, pra mim isso foi realmente um grande ganho. Eu acho minha relação com comida maravilhosa e até hoje eu levo isso, meio dia eu tenho que tá, eu tenho que almoçar, pra mim o meu almoço é o principal, às vezes eu fico até sem tomar café de manhã, como qualquer besteira, depois do almoço posso comer até qualquer besteira, mas no almoço é uma coisa que eu realmente gosto, gosto muito mesmo. Pra mim é excelente minha relação. Agora, eu tenho preguiça de cozinhar, eu não gosto de cozinhar, assim... Não é nada "nossa! Vai pra cozinha...". E até o próprio doce mesmo eu não gosto, não sou de fazer...

Não gosto de fazer pra dizer assim "ah, você é apaixonada por doce", aí faz torta, não sei o que, não sei o que. Não faço. Mas é a preguiça mesmo que não deixa. Mas minha relação com comida é maravilhosa. Hoje em dia a gente muito essa coisa de alimentação saudável, né? De comer saudável... como é que você entende isso? Eu acho um saco. Mas é porque assim, na verdade, é como eu falei. Meus hábitos alimentares sempre foi muito bom. Então pra mim é muito natural, tipo assim. Eu como fruta porque eu gosto, não é porque é mais saudável, não. Eu... eu... eu pra mim não admito ficar comendo coisas porque é saudável, sabe? Eu como as coisas porque eu gosto. Aí minha tia reclamado comigo porque eu não gosto de comer ovo cozido, é uó. Aí minha tia "Não, Simone, mas..." aí eu "Mas minha tia, eu não gosto, não vou comer uma coisa obrigada".

Não, não gosto... Gosto no bolo, gosto assim, sabe? Pra dizer assim que eu gosto... outra coisa, pra mim é inadmissível você almoçar salada... gente, salada não é almoço, salada é complemente de alguma coisa. Aí as pessoas ficam assim me olhando, sabe? Eu gosto de salada, eu gosto de verdura, eu gosto de... e assim às vezes tem episódio, eu tava almoçando com... fui almoçar com minha tia e a amiga de minha tia. Aí elas pegaram e passaram na frente e depois que eu fui... aí quando eu botei meu prato, assim. Aí a mulher "Olha o prato de Simone” aí eu achei que tava tudo arrumado, né? Sei lá... Aí eu peguei, sentei, comi. Aí depois a gente foi lanchar... aí ela pegou "Cris, seu prato, não sei o quê" 
Aí eu, tipo, percebi que ela estava falando porque eu comi pouco, né? Na verdade, eu não comi pouco, eu comi o que eu queria, eu comi o que me saciava. Aí eu peguei e falei com ela "Não, as pessoas acham que por eu ser gorda que eu como muito, não sei o que" Aquela coisa, sabe? Aquela paciência, aquela coisa de ter que... de ter que explicar, de ter que... sabe? Porque as pessoas fantasiam muito o mundo do gordo e tem coisas que não é. Tem coisas que a pessoa come demais porque gosta de comer, né? Porque está habituado a comer. Aí em relação a essas coisas saudáveis assim eu como porque eu gosto e eu acho inadmissível você só comer uma coisa porque é saudável. É... por exemplo, assim... por exemplo, eu gosto muito de azeite de oliva, mas é porque eu gosto. Eu não vou comer porque azeite de oliva é mais saudável do que ficar calculando, eu acho isso um absurdo, ficar calculando tal coisa, ficar calculando tal coisa tem mais caloria do que outro, aí eu pego e fico assim, sabe? Mas eu tento eu não quero impor também a ditadura gorda, eu não quero que todo mundo engorde, que todo mundo... Eu quero que na verdade o corpo seja livre, Luis, pra que... eu não quero sentar e dizer "ah, eu tô comendo a manga porque hoje eu tô de dieta, ei tô comendo a manga porque a manga é saudável, eu tô comendo uma maçã porque é menos calórica", sabe? Eu quero que você sente e coma o que você quiser, entende? Eu não quero... não quero também que fique cheio de explicações...

Assim, minha mãe sempre... minha mãe sempre foi muito cuidadosa, sempre falo isso assim. Minha mão foi muito gordofóbica, mas por pressão que ela tava criando uma criança gorda e era responsabilidade dela por ser gorda, por eu ser gorda, né? E... minha mãe sempre cuidou muito bem da minha saúde, eu sempre tava em médico, eu sempre tava em... em médico, assim, mas nutricionista eu não lembro, daquela época da minha adolescência se eu ia. Eu acho que eu não cheguei... eu acho que eu cheguei... Não, não cheguei a ir a nutricionista, não...Uma vez eu cheguei... um outro absurdo... fui pra uma ginecologista que me passou uma dieta, eu lembro disso. Que... mandou eu comer um monte de coisa assim, que eu não gostei. Outra coisa, porque não é o seu hábito, sabe? Eu não vou sempre comer um queijo frescal... eu não vou chegar na sua casa, achar um queijo branco frescal de não sei o quê, de nata de não sei aonde, entende? Na maioria das casas não tem queijo ou tem aqueles queijos bem amarelos que é gorduroso, entende? E além disso aqueles queijos são muito caros... E aí eu deixe de fazer, eu não lembro se eu tava já nessa fase de boa com meu corpo... mas eu acho que eu nunca fui numa nutricionista não. Pra sentar, pra fazer dieta, pra seguir, eu acho também um absurdo, não. 
Eu acho também um absurdo. É... Eu sou uma mulher inteligente, eu sei o que eu devo ou não comer, eu sei que uma coxinha é fritura e que pode causar, vai me engordar mais ou não do que eu sentar pra comer uma maçã, mas também eu não vou pra um aniversário esperando encontrar uma maçã, num aniversário, sabe? Eu não... eu não... eu acho, como eu já falei, eu sou livre, eu quero ser livre, eu quero comer o que eu quiser, mesmo que seja 100 coxinhas pra entupir minhas artérias e eu morrer ali, mas eu quero ser livre pra eu poder fazer as minhas escolhas. Isso pra mim é inadmissível, eu sentar com alguém e fazer uma dieta pra mim, eu acho um absurdo. Eu... aceito, né? Porque cada um tem que viver a sua vida do jeito que quiser, mas pra mim, Simone, eu sei o que eu posso e o que eu não posso comer, pra mim não precisa, entende? Lógico, eu entendo, por exemplo... eu exagero na quantidade, não sei sentar, chupar uma manga... eu quero chupar duas, eu quero chupar três, depois eu vou comer outra coisa.... mas, eu não admito. Isso pra mim, pra minha vida é inadmissível, sinceramente, sinceramente. Aí a gente fica "e... se você precisar? Quando eu precisar, aí a gente vê." Eu acho que já fui pra endocrinologista, se não me engano. Não lembro. Teve recentemente aquele episódio que eu te contei, lembra? Que tinha ido pra ginecologista e pra o cardiologista.

Conto? Foi ano passado isso, vai fazer um ano. Eu tinha ido pra ginecologista. E aí... é... minha Tia foi na ginecologista dela, de muitos anos e tal. E aí quando eu cheguei lá, ela... a própria ginecologista faz os exames, né? E aí ela fazendo os exames muito surpresa, né? Ela fez exame ultrassom pélvica, aí passando assim o... o aparelho, dizendo "Nossa, Simone! Tá tudo limpinho!” Aí, tipo... era pra achar o que? Tava achando que ia achar um nódulo de gordura? Não sei... Aí... é... nos seios também, “, sabe? "Nossa, Simone! Tá tudo limpinho!, que não sei o quê.”, aí tá. Eu entrei sozinha, aí depois que eu saí minha tinha falou assim "Simone peça a ela uns exames pra você fazer", normais, né? De sangue e tal. Aí eu peguei voltei e pedi a ela, aí minha tia pegou e ficou pegando no meu pé pra eu fazer, eu disse "Minha tia, eu não quero fazer porque foi final de dezembro e aí fiz no final de janeiro". Aí tinha festa de dezembro, de natal, ano novo, ainda tem as festas de lá da minha cidade, que tipo, eu ia pra casa três, quatro horas da manhã e ficava comendo um monte de besteira na rua, fritura, refrigerante, um monte de coisa. Aí minha tia "faça se não a gente vai perder, a gente vai ter que pagar outra consulta, não vai ser mais como revisão". E aí minha menstruação ia também chegar, aí foi uma loucura porque terminei por fazer. Quando eu fiz, aí eu olhei os resultados e sempre tem aquelas comparações. Aí tá, beleza. Quando eu levei pra ginecologista, quando ela abriu, que ela viu, ela abriu o 
olho assim, aí "Você precisa de um cardiologista agora!", aí saiu com meu exame, deixou eu e minha tinha na sala, "Eu mesma vou marcar pra você”. Aí foi pra recepção, aí depois ela voltou, acho que tava tão louca, voltou, chamou a gente, mandou eu e minha tia marcar. Aí eu tinha vindo pra cá pra salvador e tive que ficar aqui pra marcar o cardiologista, aí tipo, dois dias depois marcou esse cardiologista super urgente. Aí peguei fui pro cardiologista.

Ela disse... não, ela não explicou. Eu sabia que meu triglicérides tava alto, mas não explicou. Ela... tipo... eu tô... eu sou gorda, eu vou morrer daqui a pouco... o triglicérides, sei lá, alto, triglicérides, sei lá. Aí peguei e fui pro cardiologista, eu peguei e sentei, expliquei a ele, né? Que eu tinha exame, tinha dado uma alteração, ele, “ah, tá bom, sente ali." Eu mostrei o exame a ele, ele mandou eu ir. Aí ele pegou e fez o exame da carótida, aqui, o ecocardiograma no meu coração. Foi... Aí eu peguei e voltei, sentei, ele aferiu minha pressão, pressão tava alta, porque, tipo, eu também não sou de ferro, né? Eu tava com medo do jeito que... Eu tinha dito a minha tia, eu tinha dito a minhas amigas, se fosse outra pessoa, realmente naqueles dois dias, até chegar o cardiologista já tinha morrido, já tinha morrido com certeza, de infarto, de tanto medo. E aí ele pegou, sentou, ele sentou, começou a digitar um monte de coisa, aí minha calada... Aí ele pegou, falou... é...aí a gente calado, ele “Alguma dúvida?" eu "eu quero saber se os exames estão bons", ele pegou e ficou calado, não me respondeu. Aí ele começou a digitar, continuou a digitar, aí imprimiu um negócio e disse assim “Aqui, eu não sou nutricionista, mas aqui é uma dieta, você tá com o triglicérides muito alto, são coisas que na verdade..." não, ele não falou dieta. "São coisas que você deve evitar, não sou nutricionista, são coisas que você deve evitar, você tá com o triglicérides alto. Aqui é remédio pra você tomar e esse outro é um remédio pra sua pressão que eu vou trocar, porque aquele outro causa alguma coisa...", aí eu "beleza". Aí ele falou... não lembro... "quero esses exames". Beleza, eu peguei, sai, ele não me respondeu sobre... aí quando eu cheguei do lado de fora, que eu fui ver que tava, tipo, tudo normal no meu exame, não tinha nenhum tipo de problema. Aí eu peguei, fui fazer o exame... no dia que eu fui fazer o exame... é... da esteira... esqueci o nome... Teste de esforço. Que foi outro tormento também, né? Que aí eu fico, tipo, se fosse outra mulher, o que é que faria? Quando... é... eu subi na maca, na esteira... a menina já tinha dito que tava dando problema na esteira... Aí quando eu subi, a esteira parou. Aí ela pegou, tipo, tinha um monte de sala assim, ela foi chamar um médico, aliás, a enfermeira foi chamar o cardiologista. Aí eu peguei, tava lá, sentada, esperando, aí o cardiologista 
chamou outra pessoa e disse assim "ligue pra manutenção porque essa... essa... esteira tem poucos dias que teve uma manutenção, não sei o que, pergunte quanto de peso aguenta". Aí eu.... "tá, beleza, né? Respirei fundo" Aí o homem pegou e falou com a manutenção, aí... é... é... perguntou o peso, né? Acho que alguém disse que eu tava na média do peso. Aí quando o cardiologista chegou e ele falou "ah não tem problema nenhum com o peso não, eles disseram que vão fazer manutenção.” Aí eu peguei e tive que ir embora, no caso, o exame eu não consegui fazer. Aí eu fui pra Feira de Santana, pedi ainda o cartãozinho dele pra fazer em Feira de Santana, aí fui fazer o mesmo médico, ele me reconheceu, ele “ah, vamos ver se agora coisa, né?” eu disse “é, vamos”, aí também não deu nada de errado, também, aí... é... teve outro problema, né? A menina tava digitando, fez uma série de perguntas, aí eu peguei respondi. Aí teve algum problema, porque, tipo, ela parecia que ela era estagiária, aí ele pegou entrou e fui respondendo, perguntou de novo, aí... falou assim, "atividade física?” aí eu peguei botei, falei com ele "caminhada", aí ele botou lá "sedentário", na hora imprimiu, veio, tipo, sedentário. Aí, tipo, são coisas que... a gente passa a ficar desacreditada. Ninguém vai acreditar.... uma vez uma amiga falando comigo "Ah, porque você não vai pra academia, não sei o quê", eu disse "eu passei sete anos na academia" ela, tipo assim, "como assim?", porque você acha que tá na academia você tem que emagrecer, e ninguém vai acreditar que eu, Simone, faço uma caminhada, não é "nossa, ah, que maravilha! Que endorfina, que esporte maravilhoso", entende? Eu faço realmente pela necessidade que entendo que corpo tem que se movimentar, mas não é nada "nossa, maravilha", eu não gosto de acordar cedo, eu quero ter, é... eu de deixar meu tempo livre pra fazer outras coisas, não pra fazer uma caminhada, pra ir pra academia, que eu odeio academia, que é outra coisa também que eu fui muito sob pressão, né, da minha família, de que tinha que emagrecer...

É... eu odeio academia, não volto pra aquele lugar nunca mais. Posso até fazer outro tipo de esporte, mas academia eu não volto pra aquele lugar nunca mais. E... sabe, essa necessidade, você ter que emagrecer, ter que emagrecer a qualquer custo, e hoje poder dizer que eu odeio aquele lugar, que eu não vou pra aquele lugar, que eu faço atividade física como eu tô de boa, hoje eu faço, amanhã eu não faço, passo semanas sem fazer, tem dia que eu faço uma semana completo, e como eu tava falando, né? A gente termina perdendo a credibilidade, ninguém acredita que eu gosto de fruta, ninguém acredita que eu tenho hábito de caminhar, que eu faça algum tipo de esporte, povo fala assim "você faz não sei o quê”, eu fazia kickboxing, aí eu falava, "eu faço kickboxing”, aí “é mesmo, não sei o quê", eu "é..!". Nossa, é um esporte, que ninguém conhece, entende? Então a 
gente, infelizmente, a gente termina meio que perdendo a credibilidade, mas é por causa, realmente do preconceito, da questão de você não saber do gordo, né? Eu falei isso com minha tia, "a senhora não tá $24 \mathrm{~h}$ comigo" porque ela é muito incisiva, assim, né? "você tá muito gorda, você engordou mais da outra vez que você veio aqui". "Não sei, quem fica quantificando as coisas assim é a senhora. Alguns falam que eu emagreci, outros falam que eu engordei... mas, assim, eu não sei, eu não tenho esse controle. Eu não tenho a necessidade de ficar todo dia me pesando, sabe? Não tenho necessidade de ficar o dia todo praticando atividade física pra parecer mais magra, pra me sentir mais bonita, pra me sentir mais isso, entende?" Então são coisa que tem horas assim que, Luis, que eu fíco “meu deus do céu!", tem horas assim que eu fico pensando assim nas outras mulheres que são gordas, que enfrentam isso, como é que elas conseguem sobreviver, porque tem horas que parece que eu vou enlouquecer. Eu tenho uma tia avó, como é... tia avó, ela é prima de minha avó, ela criou minha avó, criou minha mãe e mais ou menos me criou. E aí, recentemente, eu fui falar com ela, porque assim... Ela não tem metade de uma perna, é cadeirante, ela tem 96 anos, então a maioria das pessoas da nossa família já faleceu, e eu fíco preocupado com ela. E eu cheguei, hoje, eu decidi evitar o máximo encontrar ela. Porque tá uma coisa insuportável, eu não conseguia manter um diálogo com minha tia, e aí da última vez, foi tipo assim... é... sacramentado, sabe? Da última vez que eu fui encontrar com ela, eu falei, eu fui... dá última vez que eu fui falar com ela... cheguei "e aí minha tia, como você tá, não sei o quê..." aí ela "você tá mais gorda", aí eu "e aí, como que a senhora tá, de hoje que eu não vejo a senhora, não sei o quê”, sabe? Tentando... Aí ela "oh minha filha, emagreça, por favor... tô tão preocupada com você" "não precisa a senhora se preocupar, não sei o que", sabe? A didática dos meus quatro anos de pedagogia, tentando imprimir nela, aí, ela... "Ah, é... não sei quem emagrece, você precisa ver como tá tão bonito" aí disse assim "eu também sou bonita" ela "não, você está feia" aí... eu "tá bom minha tia, já vou. Depois eu vou passar aqui". Nunca mais vou voltar, Luis, nunca mais, porque, tipo, é diferente... tipo... eu não fui pra casa chorar, mas eu fiquei chateada, eu fico chateada, e eu fico pensando somente nas mulheres que... não tem, não sei se é bom ter essa força que eu tenho, sabe? Que eu deveria, às vezes, dá vontade de explodir, de xingar ela toda, dizer "o que? Você é aleijada", assim... sei lá, entende? Mas eu fico assim pensando, meu deus do céu”. E aí, hoje, toda vez que eu vou pra Santo Amaro, tem um caminho que eu gosto de passar na casa dela, porque, poxa, o tempo todo, um tempão aqui, porque eu fui agora dia 6 , só vou no final do mês. E depois não sei quando é que eu vou. Então um circuito, né? De ver as pessoas que eu gosto, de 
ver meu tio, que mora comigo, de ver meu avô, são hábitos, passar pela casa dela, falar com ela, pelo menos dar um oi, porque eu não estou tão presente. Mas infelizmente ela tá fora do meu circuito, eu não tenho como, não tenho como. Eu não tenho mais como manter um diálogo com ela, porque, tipo eu tô tentando, tentando, tentando, ela tá sempre falando da mesma coisa, e isso me machuca, não machuca tanto quanto machucava antes, não é tão feroz, mas só que é ruim pra mim. Poxa, eu tô tentando manter minha autoestima, tô tentando trabalhar isso, porque é uma construção diária, aí chega uma pessoa, que é importante pra mim, uma pessoa que por eu ser educada não posso responder, sabe? Não posso falar um monte de coisa, mas infelizmente vai ter que cortar relação, porque se não, não consigo, não adianta, entende? É complicado, é complicado pra porra, é muito complicado.

É... assim, o grupo da gente fica tentando, a gente não sabe ainda como ou se vai conseguir, a médio e longo prazo, é tentando tirar... é... a obesidade, o corpo gordo como doença, né? Na verdade não tem problema nenhum. Hoje mesmo eu vejo assim, fíco olhando, eu falo com minhas amigas, eu tenho amiga que às vezes a gente sai pra comprar roupa, é... quando a gente era mais nova, a gente saia pra comprar roupa, ela tinha alguns problemas pra comprar roupa, e hoje a gente um pouco mais velha, ela já é casada, já tem uma filha e eu aqui em Salvador, a gente se encontrou, foi no shopping e ela continua com o mesmo problema, aí falou "Qual o seu problema?" "Ah, Simone, o meu braço" “Qual o problema do seu braço?" "é gordo!" "não tem problema, e mesmo que tivesse problema, que fosse um braço deficiente, que fosse sem braço, que fosse um braço mais fino, não existiria nenhum tipo de problema, que o mais que a gente vê é gente se superando com um monte de coisa". Mas aquela questão de ser... de ser uma pessoa gorda já é associado a qualquer tipo de doença. E os próprios médicos que são estudados. Eu fiz aqueles exames todos, mas pra mim não quer dizer nada, a qualquer momento eu posso morrer, Luis, entende? Não é só a questão dos exames, poxa, a gente vê tanta gente, né... Poxa, teve uma artista que faleceu, ele tinha acabado de fazer os exames, faleceu, não quer dizer nada, mas a associação de que o corpo gordo é um corpo doente, é um corpo inferior, você não sei cuida, "bora passar a se cuidar”, aí eu... né? Tipo...

É... eu não tenho hábitos, eu não tenho cuidados com meu corpo, né? Eu não faço a minha higiene pessoal, eu não me alimento direito, né? Porque as pessoas associam, principalmente agora, né? Começo de ano, vamos fazer a mudança na vida, vamos mudar, porque, pra mim, Simone, eu falo de mim, pra mim é tão normal, vai passar o ano vai 
mudar o que? Eu como fruta, eu como verdura, eu vou passar qual mudança, qual é a transformação, e essas é uma das grandes discussões, porque eles tratam a gente muito mal, e uma coisa é, por exemplo assim, a questão do meu triglicérides, realmente tava alto. "Simone, aqui tá alto.". Se fosse uma pessoa magra, ela ia perguntar, primeira pergunta, porque isso aqui aconteceu comigo. E era um médico que me acompanhava. E ele falou "Simone, você comeu alguma coisa antes de fazer o exame, sabe? Quando você fazer exame você tem que evitar, tanto que eu já tinha criado hábito que eu não queria fazer exame porque eu sabia que ia dar alterado. Porque ele me educou e me mostrou, porque já tinha acontecido isso outra vez. Mas só que a questão do médico mal informado, né? Do médico gordofóbico, né? É... achou que eu estava cheia de doença e que eu ia morrer, é... a qualquer momento, e aí quando eu voltei no cardiologista com os exames, aí ele falou, é... como é sua alimentação, aí minha tia tava do meu lado, ela disse "olhe, a alimentação dela não é ruim, ela come direitinho, não sei que" Eu disse, mas foi outra tia, “Ah, minha tia fez um elogio, que não sei o que, que bom, né?". Mas ele pegou e disse, "mas ah, você tem que tomar cuidado, porque vai chegar um tempo que você pode ter problema nas pernas" Aí é sempre, sabe? Eu nunca posso receber um elogio, eu nunca posso ter um atestado de que... não é tão importante, né? De que eu sou uma mulher gorda e surpreendentemente saudável. Ele "a médio e longo prazo pode acontecer um problema nas suas pernas, no seu quê". E hoje eu consigo perceber, às vezes eu tô com minhas amigas assim, natal mesmo eu fui falar com minha prima, minha prima tá cheia de doença, por isso que eu fico assim, e que as meninas gordas que eu ando, não tem tantos problemas como uma pessoa magra que seria saudável, não tô querendo comparar, não tô querendo dizer que a gente é melhor, mas tô querendo dizer, que isso de dizer que a mulher gorda é um poço, que a pessoa é gorda, né, é um posso de doença, um posso de possibilidades de morrer, de não sei o quê, pode acontecer com qualquer ser humano, né? E a gente tá tentando tirar, né... de que a gente pode ser uma pessoa saudável, mas é muito difícil, porque a medicina é muito forte, né? Os médicos, os advogados, ainda são vistos como aquelas pessoas detentoras do poder, se um médico, às vezes você olha assim pra um médico, o médico também tá gordo, tá te dizendo, te explicando um monte de coisa que às vezes não é uma coisa que ele faça, mas ele tá te metendo um medo que... sabe? Você... essa menina mesmo que eu falei, ela ficou apavorada porque tava chegando a hora dela ir pro médico, pra ela levar os exames pro médico, aí depois que o médico falou, que tava tudo bem, ela tipo, meio que se transforma, né? Pega uma força, e começa a falar, um tipo de discurso que a gente tem que tomar cuidado, porque a gente realmente tomar cuidado 
com a saúde, mas, sabe? Eu acho médico péssimo. Eu não de ir pra médico... Uma vez eu tava com muita dor na coluna, aí eu não queria ir pro médico porque eu já sabia, a primeira coisa que ele ia falar era porque eu tava gorda. Eu não quero ouvir isso, eu quero que você primeiro sane minha dor, independente de eu ser gorda, de eu ser magra, de eu ser azul. Eu tô com dor e quero que você sane minha dor e resolva meu problema. Porque assim, a média e longo prazo, mesmo que seja por causa do meu corpo, eu não posso emagrecer, agora, eu não vou conseguir, "ah, você tá com sobrepeso de $20 \mathrm{~kg}$, minha coluna tá doendo. Eu não vou emagrecer $20 \mathrm{~kg}$ em uma semana, entende?”. É isso que eu quero que as pessoas entendam. Não dá pra emagrecer $20 \mathrm{~kg}$ durante a semana pra minha coluna pare de doer, eu quero que você resolva isso agora. Não adianta você explicar qiue é porque eu estou gorda, entende? Então são coisas que às vezes a pessoa fala, que é desnecessário, que se você não tiver forte, se você não tiver... você termina pirando. E não sei se a gente atrai, eu não sei porque às vezes eu tô assim quieta, no meu lugar, que vem alguém falando alguma coisa, e que fico assim "meu deus! Jesus, não é comigo mesmo que você tá falando, tá falando isso", e é tempo todo as pessoas falando de emagrecer, em qualquer lugar que você vá, no outro dia eu tava no... no banco, aí a menina pegou e entrou, aí menina pegou a reclamar da caixa, da mulher, né, da mulher que tava atendendo, "ah toda vez que eu tô aqui ela faz isso, por isso que eu não gosto de ser atendida por ela, eu gosto de ser atendida por outra pessoa, se é pra tirar uma xerox ela não gosta, não sei o que.". Aí, tipo, ela tava reclamando com uma mulher que ela nem conhecia, tipo, reclamando com as pessoas que tavam na fila, aí uma mulher pegou falou assim “Ela é gorda?” Aí eu peguei soltei assim “porra, o que eu tenho a ver com isso?", aí, tipo, todo mundo na fila começou a dar risada assim, elas ficaram todas sem graça assim, tipo... mas, sabe? O que eu tenho a ver com isso? A mulher tava... a mulher ruim, a mulher não queria tirar o diabo da xerox, porque ela não queria, não tem nada a ver com ser gorda, não tem nada a ver.... e eu não tenho nada a ver com isso, entende? Eu falo com minhas amigas "poxa, às vezes a gente tá com um cara, o cara xinga você de tudo quanto é nome, mas se você xingar, dizer que você é gorda, é briga pra mais de cem anos". Aí eu vejo assim as pessoas, uma amiga da outra fala assim "ah, gorda! Não sei o que", você vai ver, tá mangando uma da outra, né? Não tá... Aí eu pego, tento ser... tento passar invisível, pra não procurar confusão, pra não, na verdade, não virar a louca, porque eu quero que as pessoas realmente entendam que não tem nenhum problema em ter um corpo gordo, é esse o meu maior objetivo, não tem nenhum problema em ter um corpo gordo, quero que todos os corpos sejam livres, independente de ser gordo, de ser magro, de você 
querer emagrecer, de você querer... engordar, quero que todo mundo tenha um corpo livre, e que não fique, "ah, bora Luis, comer essa maçã. Luis você tá comendo muita acarajé, sabe?" Aí eu fíco assim, você tem o que a ver? Você tem o que a ver com minha vida, né? Não é pra se meter, entende? É mais ou menos isso.

Acho que não... acho que tá... tá bom. A gente conduziu direito. Assim, história é o que eu mais tenho, assim, história que quando você quiser uma história eu posso contar, assim, milhares, porque é realmente isso no dia a dia, no dia a dia a gente toda hora tendo que responder, toda hora tendo que respirar fundo, é o que mais tem. Mas de história minha mesmo é basicamente isso, basicamente isso. 